\title{
THYROID ABSORBED DOSE FOR PEOPLE AT RONGELAP, UTIRIK, AND SIFO ON MARCH 1, 1954
}

\author{
A REPORT \\ Edward T. Lessard, Robert P. Miltenberger, Robert A. Conard, \\ Stephen V. Musolino, Janikiram R. Maidu, Anant Moorthy, \\ and Carl J. Schopfer \\ BNL- -51882 \\ DE85 014695 \\ Prepared for \\ Roger Ray, Nevada Operations Office \\ United States Department of Energy
}

SAFETY AND ENVIRONMENTAL PROTECTION DIVISIOA

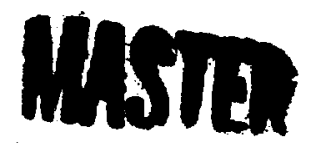

BROOKHAVEN NATIONAL LABORATORY UPTON, LONG ISLAND, NEW YORK 11973 


\section{PRETAC:}

The purpose of this report is to document the detail and data used to estimate thyroid absorbed dose to persons exposed to high levels of early fallout. The scope of the work was defined by historical records containing environmental measurement rasults and testing date for detonations in the Marshall Islands, particularly reports concerning the Castle BRAVO detonation. The records were scrutinized and data were subjected to a variety of analyses. The results of this work show agreenent between measured radiological results and the required radiobiologicai projections. The new estimated thyroid absorbed dose and the nedical factors relating to health effects in the Marshall Islands any be used to estimate potential health effects in other populations exposed under similar conditions. 


\section{ACANOWLEDGENTS}

The author fully appresiate the efforts of victor Bond, Robert Conard, and Charles Keinhold of Brookhaven National Laboratory to initiate this tudy. Nathanial Greenhouse is to be comended for plenning the meteorological and archival soil studiea. Bruce Weehholz, partment of Energy are thenked for providing funding and support for the duration of the work.

The authors gratefully acknowledge the work of Fred Brauer of Battelle Pacific Northwest Laboratory who prepared and analyzed the archival soils. We also extend thanks to Rendall Peterson of Lawrence Livermore National Laboratory for computer simulation of the behavior of the BRAvO fallout cloud.

Much calculational work was performed by Lee Kaplan, c froa Yale University; the authors are grateful.

The authors thank the mary persons tho reviewed drafts of the manuscript. These persons contributed new deas and better procedures along with editorial coments. They were John Bark, Donald Borg, Eugene Cronkite, Willian Adans, and Andrew Hul1, all from Brookhaven National Laboratory, and Charlea Sondhaus from the University of California.

A special thanks goes to Barbara Boccia Lessard, a physician in private practice and wife of the principal investigator. Her thoughtful and scientific coment, advice, and encouragement are warmly appreciated.

\footnotetext{
acurrently with Lawrence Berkely Laboratory.

bCurrently with National Cancer Institute.

CCurrently with Texas Instruments Corporation.
} 
CONTENTS

Page

Preface $\ldots \ldots \ldots \ldots \ldots \ldots \ldots \ldots \ldots \ldots \ldots \ldots \ldots \ldots \ldots \ldots \ldots \ldots \ldots \ldots \ldots \ldots \ldots \ldots \ldots \ldots \ldots$ 111

Acknowledgments $\ldots \ldots \ldots \ldots \ldots \ldots \ldots \ldots \ldots \ldots \ldots \ldots \ldots \ldots \ldots \ldots \ldots \ldots \ldots \ldots \ldots \ldots$

List of Tables $\ldots \ldots \ldots \ldots \ldots \ldots \ldots \ldots \ldots \ldots \ldots \ldots \ldots \ldots \ldots \ldots \ldots \ldots \ldots \ldots \ldots \ldots \ldots \ldots \ldots$ ix

List of Illustrations $\ldots \ldots \ldots \ldots \ldots \ldots \ldots \ldots \ldots \ldots \ldots \ldots \ldots \ldots \ldots \ldots \ldots \ldots \ldots \ldots \ldots$

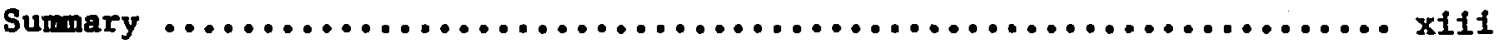

I. Introduction $\ldots \ldots \ldots \ldots \ldots \ldots \ldots \ldots \ldots \ldots \ldots \ldots \ldots \ldots \ldots \ldots \ldots \ldots \ldots \ldots \ldots$

II. Methods and Results $\ldots \ldots \ldots \ldots \ldots \ldots \ldots \ldots \ldots \ldots \ldots \ldots \ldots \ldots \ldots \ldots \ldots \ldots \ldots$

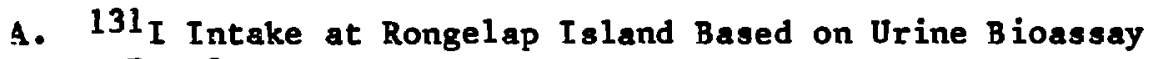

Results ..................................... 5

B. Radioiodine Air Concentrations Based on Meteorology ....... 5

1. Calculation of BRAvo Fallout Patterns .............. 5 5

2. Comparison of Whole-Body Dose Estimates............... 7

3. Duration of Fallout ........................... 8

4. Rate of Rise-of-Exposure Rate .................... 9

5. Comparison of Airborne Activity Concentrations ......... 9

C. Radioiodine Surface Activity Based on Archival Soil Analysis

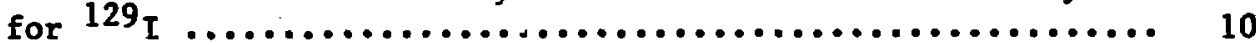

1. The Archival Soil Sample Collection ................ 10

2. Analysis of Samples ........................... 10

3. Estimate of Initial Surface Activity ................ 12

4. Ratio of Nuclide Activity to Total Fallout Activity in Archival Soils ............................. 12

5. The Ratio of Nuclide Activity to Fission Product Activity for Thermonuclear Fission ...................... 14

6. The Ratio of Nuclide Activity to Total Activity for

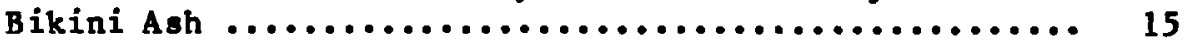

7. Comparison of Archival Soil Measurements to Thermonuclear Fission Data and Bikini Ash Estimates ..............

8. Estimation of Radioiodine Activity per Unit Area Based on Soil Activity for ${ }^{129}$ I ...................... 18

D. Thyroid Absorbed Dose Estimate Based un Bikini Ash Results .. 19

1. Surface Activity and Exposure-Rate Estimates .......... 19

a. Nuclide Composition .......................... 19

b. The Decay of Fallout ........................ 21 
c. The Buildup of BRavo Fallout on the Ground ..........

d. A Simple Model for Bxposure-Rate History at Rongelap, Sifo, and Utirik Islands .....................

e. Activity and Exposure-Rate History Based on Bikini

Ash ..................................

i. Areal Activity and Exposure Rate fron Nuclides

Observed on Day $26 \ldots \ldots \ldots \ldots \ldots \ldots \ldots \ldots . \ldots . \ldots 30$

ii. Areal Activity at Fallout Cessation ........... 31

iii. Areal Activity of Nuclides Without Descendants

in Bikini Ash ...................... 32

iv. Non-Fission-F ragment Nuclides Not Accounted

for ............................ 37

v. Input Data to Rinetics Equations ............. 38

vi. Exposure Rate on Day 0.5 and Surface Roughness Effects ........................... 38

vii. Integrated Exposure and Whole-Body Absorbed

Dose ..................................

2. Radioactivity in Food, Water Supplies, and Air .........

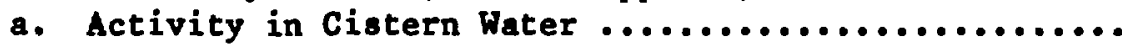

b. Activity Ingested with Lrinking Water .............

c. Activity in Food .............................

d. Activity Ingested with Meals .....................

e. Activity Concentrations in Air ..................

F. Activity Intake by Inhalation ...................

g. Total Activity Intake ........................ 54

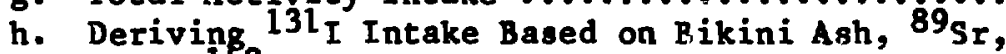
and $140_{\mathrm{Ba}}$ in Urine on Day 45 Post-Detonation ...... 54

i. Absorption Through Skin .................... 57

3. Absorbed Dose for Individuals ..................... 57

a. Absorbed Dose per Unit Activity Intake ............ 57

b. Thyroid Absorbed Dose ........................ 57

c. Maximum Thyroid Absorbed Dose .................... 60

d. External Sources of Thyroid Dose ................. 60

III. Thyroid Nodule Risk and Thyroid Cancer Risk from Exposure to

Fallout $\ldots \ldots \ldots \ldots \ldots \ldots \ldots \ldots \ldots \ldots \ldots \ldots \ldots \ldots \ldots \ldots \ldots \ldots \ldots \ldots \ldots \ldots \ldots \ldots \ldots \ldots \ldots \ldots \ldots \ldots$

A. Tabulation of Thyroid Effects and Age at Exposure ......... 62

B. Tabulation of Risk of Thyroid Cancer $\ldots \ldots \ldots \ldots \ldots \ldots \ldots \ldots \ldots \ldots .62$

C. Comparison to Other Estimates of Risk of Thyroid Cancer ..... 62

D. Estinate of the Uncertainty in the Derived Risk Estinate .... 


\section{LIST OF TABLES}

Table

1

2

3

4

5

6

7

8

9

10

11

12

13

14

15

16

17
Title

Pare

Fraction of Initial ${ }^{131}$ I Activity Ingested

That Is Excreted on Given Day Post-Intake

Compariaon of Cumulated Whole-Body Dose, Rad

7

Duration of Fallout, Hours

8

Measured and Predicted Rate-of-Rise of Exposure Rate at Rongerik Atoll

10

Air Activity Concentrations

11

Soil Sample Results for Rongelap and Utirik Islands

13

Archival Soil Results Compared to Thermonuclear Fission and Bikini Ash Results

16

Activity of Iodine Isotopes Based on Archival

Soil Results

Measured BRAVO Fallout Composition and Unfractionated Composition on Day 26

BRAVO Gamma or Beta Exponent Indicated by Miller for $\mathrm{Fission}$ Products

BRAVO Fallout Exposure-Rate Decline Based on Miller's Decay Estimates

BRAVO Fallout Beta Activity Related to BRAVO

Fallout Exposure Rate

Bstimated Unweathered Activity on Surface and Exposure Rate at One Meter, Rongelap Island

Average Estimate of Radioiodine Activity in Cistern Water and Time After the BRAvo

Detonation

Average Estimate of Activity Intake from

Cistern Water

45

Surface Activity and Time After BRAVO

49

Average Estimate of Activity Intake with MEals

51 


\section{LIST OF TABLES}

Table

18

19

20

21

22
Title

Page

Air Activity Concentration of Selected Nuclides

Average Estimate of Inhaled Activity

Total Radioiodine and Radiotellurium Activity

Intake and Corresponding Age

Radioiodine and Radiotellurium Thyroid AbsorbedDose Commitment per Unit Activity Intake and Corresponding Age

Estimated Radioiodine and Radiotellurium Thyroid Absorbed Dose and Corresponding Age

Total Thyroid Absorbed-Dose Estimate

Tabulation of Thyroid Results

63

Summary of Thyroid Results
55

53 6

64 


\section{LIST OR ILLUSTRATIONS}

Figure

Title

Pare

1

2

3

4

5

6

7

8

9

10

11

12

13
Illustration of approach

Relative location of atolls and people

Curve fit of archival soil results

Activity $v 8$ granule diameter for Bikini

ash

Cumulative 7 of activity deposited on the 5 th Lucky Dragon vs time post-BRAvo detonation

Activity vs granule diameter for Rongelap Island fallout

Cumulative $\%$ of activity deposited on Rongelap Island vs time post-BRAvo detonation

Activity vs granule diameter for Utirik

Island fallout

Cumulative $Z$ of activity deposited on

Utirik Island vs time post-BRAVO detonation

Exposure-Rate histories for Rongelap, Sifo, and Utirik based on Bikini ash characteristics

Integrated exposure vs time

40

A cistern at Rongelap Island

41

Photographs of food preparation techniques and living patterns at Rongelap and Utirik Is lands 


\section{SUMMARY}

A study was undertaken to reexamine thyroid aboorbed dose estimates for people accidentally exposed to fallout at Rongelap, Sifo, and Utirik Islands from the Pacific weapon test known as Operation Castle BRAvo. The study included: 1) reevaluation of radiochemical analysis, to relate results from pooled urine to intake, retention, and excretion functions; 2) analysis of neutron-irradiation studies of archival soil samples, to estimate areal activities of the iodine isotopes; 3 ) analysis of source term, weather data, and meteorological functions used in predicting atmospheric diffusion and fallout deposition, to estimate airborne concentrations of the iodine isotopes; and 4) reevaluation of radioactive fallout, which contaminated a Japanese fishing vessel in the vicinity of Rongelap Island on March 1, 1954, to determine fallout components. The conclusions of the acute exposure study were that the population mean thyroid absorbed doses were 21 gray $(2,100 \mathrm{rad})$ at Rongelap, 6.7 gray $(670 \mathrm{rad})$ at $S i f o$, and $2,8 \mathrm{gray}(280 \mathrm{rad})$ at Utirik. The overall thyroid cancer risk we estimated was in agreement with results published on the Japanese exposed at Nagasaki and Hiroshima. We now postulate that the major route for intake of fallout was by direct ingestion of food prepared and consumed outdoors.

We believed urine bioassay results for ${ }^{131}$ I excreted from people exposed at Rongelap to be accurate. We extrapolated our thyroid dose estimates from measured and derived quantities which were related to urine bioassay results. The facts which related were 1) fallout arrival and observation times, 2) size and nuclide composition of BRAVO fallout (also known as Bikini ash), 3) Rongelap, Utirik and Sifo Island exposure-rate measurements and 4) diet and living pattern observations. The 131 I intake, which we estimated from 131 I measured in urine, was used by us as a normalization point to link related facts. This allowed us to estimate the intake of other iodine isotopes and the intake of radiotelluriums.

Studies used by us to deduce the amount of ${ }^{129}$ I deposited at Rongelap and Utirik as a result of the BRAVO detonation revealed a much greater level of 129 I in soil than could be derived by using other methods. Additionally, the uncertainty associated with soil measurements was very great. We concluded that other weapons tests may have influenced the soil concentrations of ${ }^{129} I$ and that isobars rather than isotopes of ${ }^{129}$ I may have exhibited similar behavior. Thus, using ${ }^{129}$ I to derive the intake of other radioiodines was not possible.

The meteorological approach used to assess thyroid dose did not result in agreement with relatable quantities. The value for predicted increase in exposure rate based on meteorology, or the meteorological-based estimate of wholebody dose, duration of fallout, or airborne activity concentration were not consistent with values obtained by measurement or estimates derived by different methods.

The composition, specific activity and particle size of BRAVO fallout (Bikini ash) were in agreement with other observed facts. Based on BRAvo fa11out composition and specific activity studies, surface activity results which we derived for varous locations downwind of the detonation site were in agreement with directly measured surface activities made at these same locations shortly 
after the accident. In addition, fallout duration and fallout arrival estimates derived from BRAvO fallout studies were in agreement with the observed fallout duration and arrival times. Our estimates of aurface activity were tranaformed into estimates of surface exposure and exposure rate on an individual nuclide basis. The measured exposure and exposure-rate results reported in the literature were used to develop surface activity at locations and times of interest. Otice the surface activity was deriyed, the intake pathway and estimate of intake were evaluated using the average ${ }^{131_{I}}$ excreted by Rongelap adults for normalization.

Estimates of thyroid absorbed dose, age at exposure, ant intake of specific nuclides were tabulated for each location. For an adult wale, the thyroid absorbed dose from iodine and tellurium radionuclides was 7.7 times the absorbed dose from ${ }^{131}$ I at Rongelap, 10 times that at Sifo Island, and 4.7 tines that at t?tirik Island. James, in an earlier attempt to estinate thyroid absorbed dose based on $131_{I}$ in urine, assumed the total dose was 2.6 times the dose from $131_{I}$ (Ja64). The factor 2.6 would be appropriate for slightly older fallout than that experienced at Rongelap, Utirik, and Sifo Islands. Our estimate of thyroid absorbed dose was based on ingestion intake. Inhalation intake and absorption through skin could not be reconciled with measurements of 131 I in urine or with external exposure-rate measurements.

The average and maximum estimates of total absorbed dose to the thyroid were derived. Observations of the range of ${ }^{137} \mathrm{Cs}$ body burdens during protracted exposure (Mi79) and Eve's estimate of the range associated with the contents of the stornach in cases of sudden death (Ev66) were used to estimate maximum thyroid absorbed dose. The maximum was estimated to be four times the average. The average internal thyroid dose at Rongelap Island was based on the average 131 I activity collected in urine. The contribution to thyroid dose from external sources was estimated from the air exposure caused by the decay of 142 nuclides making up the fallout composition. The external doses were similar to original estimates by Sondhaus for persons exposed at Rongelap and Utirik Islands, 1.75 gray and 0.14 gray ( $175 \mathrm{rad}$ and $14 \mathrm{rad}$ ), respectively, which were derived from survey instrument readings taken at evacuation and film badge data from a nearby military outpost (So55). The external dose estimated for people at Sifo Island, 1.1 gray ( $110 \mathrm{rad),} \mathrm{was} \mathrm{greater} \mathrm{than} \mathrm{the} 0.69 \mathrm{gray}$ ( $69 \mathrm{rad}$ ) estimated original1y from post-evacuation surveys of exposure rate. The difference was due to the presence of very short-lived activation and transuranic nuclides which, according to the nuclide composition, must have been present during exposure at sifo Is land.

Medical observations concerning thyroid abnormalities have been tabulated along with the new thyroid dose estimated for each person. From these results, the mean cancer risk rate in the exposed population of 251 people was 150 thyroid cancers per million person-gray-years at risk ( $1.5 \pm 2.3$ thyroid cancers per million person-rad-years at risk). The mean time at risk for thyroid cancer was 19 years. The mean thyroid nodule riak rate was 830 nodules per million person-gray-years at risk ( $8.3 \pm 12$ per million person-rad-years at risk). The mean time at risk for a thyroid nodule was 18 years. 


\section{INTRODUCTION}

Persons who were present on March 1, 1954, at Rongelap Island, Rongelap Atol1; Sifo Island, Ailingnae Ato11; and Utirik Island, Utirik Atoll; in the Marshall Islands, have been examined by medical specialists to determine if any observable effects can be attributed to exposure to radioactive fallout. Their original estimates of external whole-body dose from the acute exposure were 1.75 gray (175 rad) at Rongelap and $0.14 \mathrm{gray} \mathrm{(14} \mathrm{rad)} \mathrm{at} \mathrm{Utirik} \mathrm{(Cr56).} \mathrm{The} \mathrm{first}$ estimate of thyroid dose from internal emitters in Rongelap people was 100 to 150 rep $^{*}$ (Cr56). Thus, the first estin te of total thyroid absorbed dose was 2.58 to $3.15 \mathrm{gray}(268$ to $315 \mathrm{rad}$ ) for $k$ igelap people in general and for internal plus external exposure.

Medical specialists have reported short-term effects exhibited over a period of many months and possible long-term effects exhibited over many years. In 195', three teenage females who were exposed in 195't underwent surgery for benign thyroid nodules. In 1964, 3- to '-year-old child thyroid dose was reexamined by James on the basis of 1) urine bioassay results and 2) a range of values for thyroid burden of ${ }^{131} \mathrm{I}$, thy roid mass, uptake retention functions, and ingestion or inhalation. For 3- to 4-year-old girls, the extreme range of thyroid dose from internal emitters was estimated at 2 to 33 gray (200-3300 rad). The most probable total thyroid dose was in the range of 7 to 14 gray (700-1400 rad). The James estimate of most probable total thyroid absorbed dose to the child was two to five times higher than the estimate reported by Cronkite for Rongelap people.

The value for the James estimate of total thyroid dose was extrapolated to other ages and to the Utirik people and reported along with medical effects by Conard (Co74). The number of radiation-induced thyroid lesions per million person-rad-years at risk was tabulated by Conard for the Rongelap and Utirik. exposed populations (Co74). It was slear that the risks of radiation-induced benign and cancerous lesions for the two atolls were not comparable for any age grouping. The thyroid cancer risk for the Japanese population exposed at Nagasaki and Hiroshima, in units reported by the National Research Council's Committee on the Biological Effects of Ionizing Radiation, was 1.89 excess cases per million person-rad-years of tissue dose (CBEIR80). This parameter was 7.0 at Rongelap and 17.8 at Utirik for the 10-year and older age grouping in 1974 $(\mathrm{Co} 74)$.

Variation in risk of radiation-induced thyroid cancer between ato $11 \mathrm{~s}$ and the difference when compared to other irradiated groups had become an important scientific and health-related question with considerable political overtones. Early in 1977, Bond, Borg, Conard, Cronkite, Greenhouse, Naidu, and Meinhold, a11 members of Brookhaven Nationa1 Laboratory (BNL), and Sondhaus, University of California, College of Medicine, initiated a reexamination of the technical issues. In 1978, forma 1 program objectives and funding were supplied to BNL by the Department of Energy's Division of Biological and Environmental Research.

* An obsolete unit of absorbed dose; 1 rep $=0.93$ rad for soft tissue. 
In June 1978, the Meteorology Division at Lawrence Liverwors Mational Laboratory was subcontracted to provide a computer imulation of the diepersion, transport, and deposition of fallout from the 1955 atwopheric nuclear test, BRAVO. A subcontract to provide neutron activation analyeis of archival soil sanples was given to the Radiological Sciences Department, Battelle-Pacific Northwest Laboratory. Soil samples were provided by Seymour, Director of the University of Washington's Laboratory of Radiation Bcology.

During 1980, nembers of BRL researched the protracted exposure to fallout at Rongelap and Utirik Ato1ls. The interval of interest was from tre time each population returies co their hone atoll up to 50 years later. The nuslides considered were ${ }^{137} \mathrm{Cs}, 60 \mathrm{Co}, 90 \mathrm{Sr}, 55_{\mathrm{Fe}},{ }^{6} 5 \mathrm{Zn}$, and ${ }^{239} \mathrm{Pu}$. Thyroid absorbed dose from thess sources was negligible relative to the thyroid dose comitted during the first few days after the accidental exposure (Le84).

The subject of this report is the estination of thyroid absorbed dose due to fallout exposure of the inhabitants of Rongelap, Utirik, and sifo Islands on March 1, 1954. To determine thyroid dose, the anount of fallout activity taken into the body was efrimated by reexamining the ${ }^{131}$ I excreted from persons wo were at Rongelap. The other components of fallout taken into the body had to be inferred from studies on fallout composition. Initially, fallout composition was assumed and nuclide activity concentrations in air, water, and fooci were established on the basis of meteorological and archival soil study results. Further study led to dose estimstes based on actual BRAVO fallout composition rather than hypothetical composition. Finally, knowledge was gathered about the intake pathway and the time post-detonation at which intake was likely to have occurred, and this was factored into the thyroid absorbed dose estimates.

The report was prepared under the authorization of the Department of Energy's (DOE) Division of Biological and Environmental Research, wich provided funding and review from 1978 until 1983. After organizational changes at DOE in 1983, funding and review were provided under the DOE Office of Military Application.

The purpose of the study was to clarify or document further the relationship between thyroid absorbed dose and incidence of thyroid nodules or thyroid cancer. The high incidence of benign and cancerous thyroid lesions was very evident (Co74). Our efforts were directed towards reevaluation of thyroid absorbed dose estimates upon which Conard's risk estimates were based.

The limitations for applying the risk estimated here to other exposed groups include the following: 1) thyroid dose estimates have a large standard error, 2) thyroid dose estimates apply to a unique situation involving ingestion of fallout plus external irradiation, and 3) the medical observations quoted are not infallible, that is, a reevaulation of medical results may result in reclassifications of thyroid lesions, or reveal other cancer sites, or additional thyroid lesions.

The sources of information were many and varied. Discuseions with persons instially engaged in these studies, e.g., Stanton Cohn, Victor Bond, and Bugene Cronkite, led to review of documents wich are cited in the references of this 
report. A search for records at DOE headquarters led to the files currently held by Thomas McCraw who has acted as a repository for weny Atomic Energy Commission documents. Some of these documents related diractly to this study and were not easily located anywhere else. An abundance of tnvironmental results have been published by the University of Washington's Luloratory of Radiation Ecology (also known as Applied Fisheries Laboratory). Medical information was published by BNL's Medical Department and by the Safety and Environiental Protection Division. Much of the early and detailed observations on the accidentally exposed Marshallese were recorded in documents published by the U.S. Naval Radiological Defense Laboratory and by the Nava1 Medical Research Institute.

The plan of this report is to document the details of the dose reassessment. Two methods, 1) the estimate of 131 I intake from urine results, and 2) the estimate of particle size and nuclide composition from Bikini ash results, could be related to each other and the known facts about arrival and duration of fallout, external exposure-rate measurements, and gross beta measurements. A schematic of the approach is given as Figure 1 .

Once the nuclide composition and fallout arrival and duration times were assessed, the composition was normalized to external exposure-rate measurements. Exposure-rate histories and corresponding surface activity histories were then constructed for each island. Estimates of intake of radioiodines and radiotelluriums were based on the ${ }^{131}$ I intake estimate which was in turn normslized to the Rorgelap urine results. The time and mode of intake were based on observed diet and living patterns. The population mean and individual thyroid absorbed dose estinates were based on the age and locstion of the exposed people. Age-dependent values of thyroid absorbed dose per unit activity intake were taken from the scientific 1iterature.

The final step was to obtain internal and external thyroid absorbed dose estimates for 251 exposed people. This was related to medical observations and summarized in the final section of the report. This relationship is presented in terms of thyroid cancer incidence per unit absorbed dose per million person years at risk. 


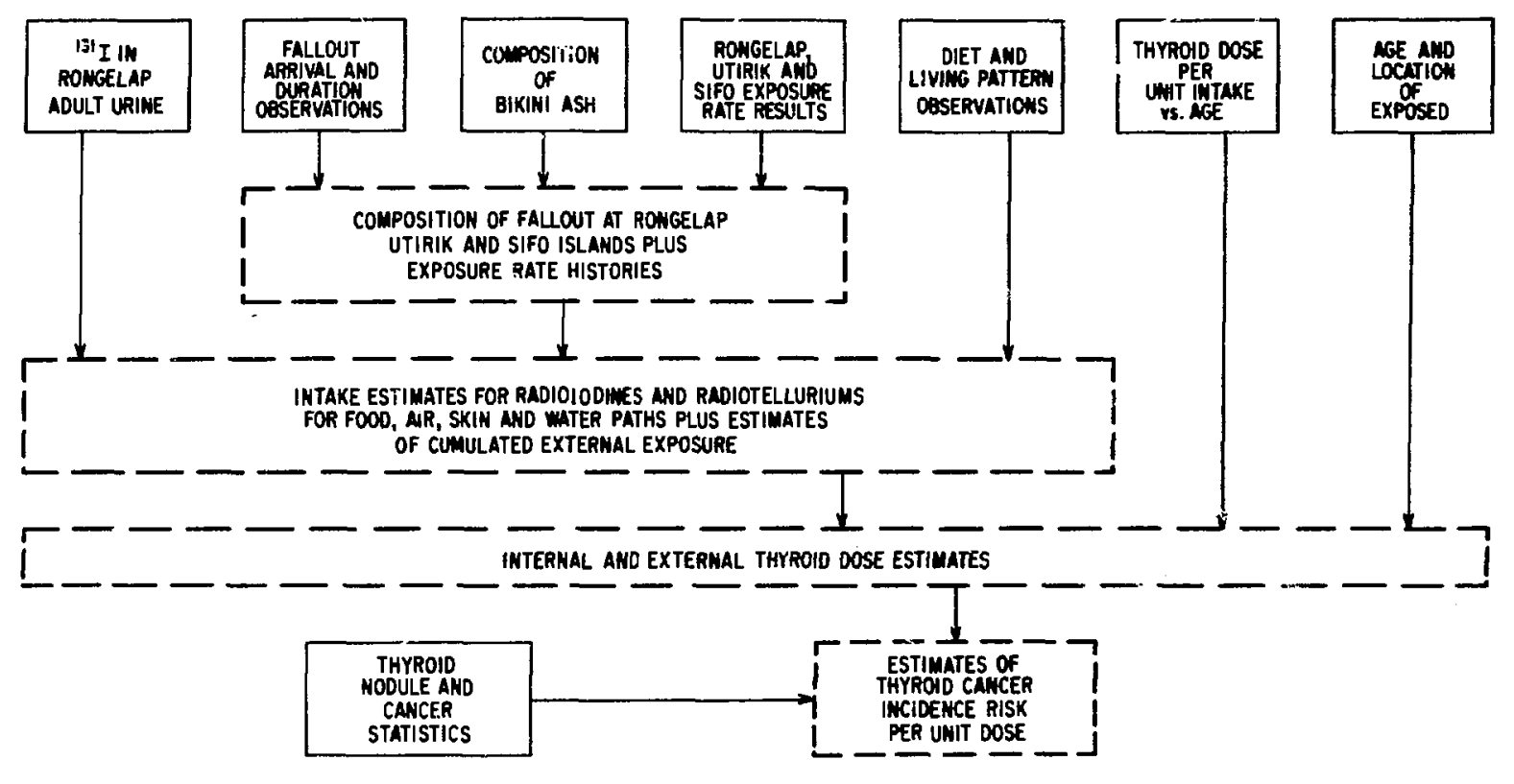

¿--

Figure 1. Schematic of approach. 


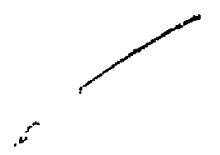

\section{METHODS AND RESULTS}

\section{A. 131 I Intake at Rongelap Island Based on Urine Biosssay Results}

Urine samples for 24-hour elimination were pooled and collected on the 17 th day post-detonation from persons evacuated from Rongelap Island (Co72). The urine was sent to Harris/at Los Alamos Scientific Laboratory and an estimate of thyroid-absorbed dose from internal emitters was reported by Cronkite ( $\mathrm{Cr56}$ ). The 64-person crmposite urfne sample was $75 \%$ adult urine (18 $l,>16$ years of age), $20 \%$ adoiescent and thild urine (4.8 l, 5-16 years of age), and 4.87 child and infant urine ( $1.2 \ell,<5$ years of age) ( Ja64). Harris indicated a mean activity of $0.48 \mathrm{kBg}\left(1.31 \times 10^{-2} \mu \mathrm{Ci}\right)$ of $131_{\mathrm{I}}$ in the Rongelap adult 24-hour urine taken on the 17 th day post-detonation (Co72) and an adult mean peak thyroid content of $414 \mathrm{kBq}(11.2 \mu \mathrm{Ci})$ (Ha54). This peak estimate was calculated on the assumption that 0.17 of stable iodine burden on the first day would be eliminated via urine between the 15 th and $17^{\text {th }}$ days (Co72).

Table 1 is a tabulation of the fraction of an initial ${ }^{131}$ I activity intake by ingestion that would be eliminated by an adult on a given day post-intake. Two models were used to calculate these daily fractions, one developed by Johnson (Josi) and the other by ICRP (ICRP79). Both models had feedback incorporated into the estimate of the fraction of initial intake. Both were solved using catenary compartment kinetics and both led to similar values for elimination of $131_{I}$ by a reference man. Values for fractions of an initial intake excreted by female individuals were higher than for males on days 10 and 25 but were the same on day 17. A comparison to an excretion function based on results for a normal adult male was made and values were tabulated for the intake of stable iodine (see Table 1). The stable fraction compares indirectly with the ${ }^{131}$ I fraction through adjustment for radioactive decay.

On the basis of $0.48 \mathrm{kBq}\left(1.31 \times 10^{-2} \mu \mathrm{Ci}\right)$ in adult urine on the 17 th day post-intake, a $3440 \mathrm{kBq}(93 \mu \mathrm{Ci})$ intake was estimated for ${ }^{131} \mathrm{I}$. At Rongelap Island, ingestion at 0.5 -day post-detonation was assumed.

The intake of $3440 \mathrm{kBq}(93 \mu \mathrm{Ci}$ ) was used as a normalization point. That is, once we had determined the relationship between $131_{\text {I }}$ and the othar nuclides in fallout, we estimated the contribution to thyroid dose from all radioiodines, while keeping the $131_{\text {I }}$ intake at $3440 \mathrm{kBq}(93 \mu \mathrm{Ci})$. A similar method used by Cole and James to estimate thyroid absorbed dose (Co72,3a64) differs from ours in that 1) we used the relationship between radioiodines and 131 I based on BRAvo fallout measurements, 2) we based the intake time (post-detoriation) on diet and living pattern observations, and 3 ) we determined the mode of intake to be ingestion.

\section{B. Radioiodine Air Concentrations Based on Meteorology \\ i. Calculation of Bravo Fallout Patterns. Downwind exposure-rate con-} tours for the BRAVO detonation were estimated by several groups (Armed Forces Special Weapons Project, Rand Corporation, Naval Radiological Defense Laboratory) (Ha79), These sontours, which were based on observations of BRAVO cloud dimensions and hodographs developed for 3 hours, 6 hours, and 9 hours post-detonation, 
Table 1

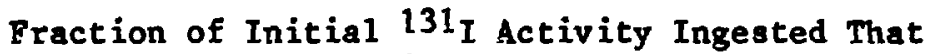

Is Excreted on Given Day Post-Intake

\begin{tabular}{cccc}
\hline $\begin{array}{c}\text { Days Post- } \\
\text { Intake }\end{array}$ & $\begin{array}{c}\text { Reference } \\
\text { Fema le }^{\mathrm{a}}\end{array}$ & $\begin{array}{c}\text { Reference } \\
\text { Male }\end{array}$ & $\begin{array}{c}\text { Reference } \\
\text { Male }^{\mathrm{b}}\end{array}$ \\
\hline 1 & - & - & $4.4 \times 10^{-1}$ \\
5 & $1.4 \times 10^{-4}$ & $1.4 \times 10^{-4}$ & $1.4 \times 10^{-4}$ \\
10 & $1.9 \times 10^{-4}$ & $1.8 \times 10^{-4}$ & $1.9 \times 10^{-4}$ \\
17 & $1.4 \times 10^{-4}$ & $1.4 \times 10^{-4}$ & $1.4 \times 10^{-4}$ \\
25 & $9.2 \times 10^{-5}$ & $8.0 \times 10^{-5}$ & $9.0 \times 10^{-5}$
\end{tabular}

Fraction of Stable Iodine Ingested That Is Excreted on a Given Day Post-Intake for a Normal Adult Male

\begin{tabular}{cccc}
\hline $\begin{array}{c}\text { Days Post- } \\
\text { Intake }\end{array}$ & $\begin{array}{c}\text { Reference } \\
\text { Malea }\end{array}$ & $\begin{array}{c}\text { Reference } \\
\text { Male }\end{array}$ & $\begin{array}{c}\text { A Norma1 } \\
\text { Male }^{c}\end{array}$ \\
\hline 1 & - & $4.5 \times 10^{-1}$ & $4 \times 10^{-1}$ \\
5 & $2.3 \times 10^{-4}$ & $2.3 \times 10^{-4}$ & $9 \times 10^{-4}$ \\
10 & $4.3 \times 10^{-4}$ & $4.6 \times 10^{-4}$ & $7 \times 10^{-4}$ \\
17 & $5.4 \times 10^{-4}$ & $6.4 \times 10^{-4}$ & $7 \times 10^{-4}$ \\
25 & $6.9 \times 10^{-4}$ & $7.5 \times 10^{-4}$ & $7 \times 10^{-4}$ \\
\hline
\end{tabular}

äJohnson Kode1 (Jo.9l).

bICRP 30 Model (ICRP79).

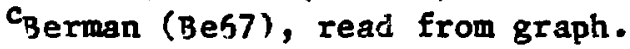

do not all agree but are within a factor of 2 for any specific location at Rongelap and Utirik Atolla. A significant difference between the Armed Forces, Rand and Naval exposure-rate contours occurs 32 tc $190 \mathrm{~km}$ (20 to $120 \mathrm{miles}$ ) north of Rongelap Atoll out to a distance of $480 \mathrm{~km}$ (300 niles) east of the detonation site. See Figure 2 for the relative location of the atolls and people.

Peterson estimated downwind exposures using a modified MATHEW-ADPIC computer code (Pe81) Additional1y, Peterson developed instantaneous activity concentrations for ${ }^{129} \mathrm{Te}, 131_{\mathrm{I}}, 133_{\mathrm{I}}, 137 \mathrm{Cs}$, and ${ }^{155_{\mathrm{Eu}}}$ for Ailinginae Atoll and the southeastern part of Rongelap Atoll near Rongelap Island. The computer codes were developed for the Atmospheric Release Advisory Capability of the Department of Energy. They were modified to include a larger number of upper-air 


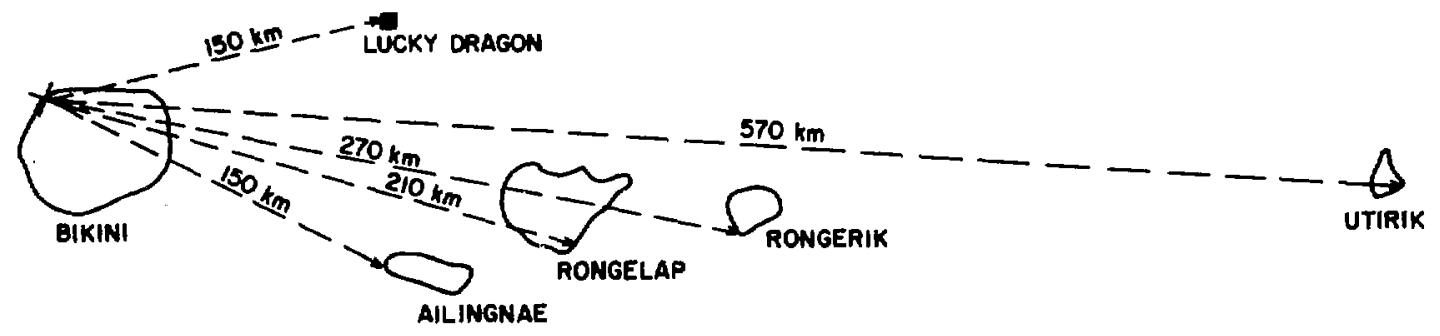

Figure 2. Relative location of the atolls and people.

wind levels which was thoúght by Peterson to be important. An additional modification included a turbulent wake correction to large granules falling from the stratosphere. Parameters for a tropical atmosphere were incorporated into granule fall velocity calculations. An assumption was made that the activity per granule increased as the cube of granule radius increased. The analytical approach has been described by Peterson (Pe81).

2. Comparison of Peterson's Whole-Body Dose Estimates. The cumulated whole-body dose was integrated from the onset of fallout to evacuation time. Peterson calculated the diffusion of fallout using computer codes and upper-air wind-level patterns. Peterson's results for whole-body dose were compared to estimates by Dunning (JCAE57) and Sondhaus ( Cr56), and an estimate based on our analysis of Bikini ash. Sondhaus's work was detailed (So55); the whole-body dose was based on exposure-rate measurements and a range of assumed times for the onset and cessation of fallout. Sondhaus's best estimate of whole-body dose is given in Table 2, as are Peterson's estimate, the Dunning estimate, and the Bikini ash result (see column labeled 'This Report').

The valuea for whole-body dose estimated by Dunning and Sondhaus, and those estimated by the method indicated in Section II.D of this report are in

Table 2

Comparison of Cumulated Whole-Body Dose, $\operatorname{Rad}^{a}$

\begin{tabular}{lcccc}
\hline $\begin{array}{l}\text { Location } \\
\text { of People }\end{array}$ & $\begin{array}{c}1955 \\
\text { Sondhaus }\end{array}$ & $\begin{array}{c}1957 \\
\text { Dunning }\end{array}$ & $\begin{array}{c}1981 \\
\text { Peterson }\end{array}$ & $\begin{array}{c}1984 \\
\text { Thio Report }\end{array}$ \\
\hline Rongelap & 175 & 170 & 110 & 190 \\
Ailingnae & 69 & 75 & 24 & 110 \\
Jtirik & 14 & 15 & 0.33 & 11 \\
Rongerik & 78 & - & 340 & 81 \\
\hline
\end{tabular}

au1tiply by 0.01 to obtain gray. 
reasonable agreement. These last two approaches were different from each other in that Sondhaus derived the estimate of whole-body dose from actial masurements of total exposure (film badges at Rongerik) and exposure rate, while the estinate using Bikini ash depended upon weasurewents of the comosition of fal1out and exposure rate. The approach used by Peterson depended on upper-air wind level patterns and the fallout was estimated by hin to drift back in a southerly fashion. This was not in agreement with assumptions regarding wind level patterns which were used in three previous and independent approaches (Ha79). The Peterson results for whole-body dose were radically different from other estimates for Rongerik and Utirik people and do not coincide with measured values for exposure and exposure rate (Sh57).

3. Duration of Fallout. Duration of fallout is defined as the time fal1out begins up to the time of cessation (not to be confused with the time of evacuation, wich was much later). Peterson's estimated duration of fallout (see Table 3) of about 19 hours at Rongelap appears to be too long relative to the reported wind velocity moving the cloud past Rongelap (Cr56) and relative to the first-hand accounts of fallout duration given by the Marshallese evacuated from Rongelap Island (Sh57). An upper limit of 16 hours' duration at Rongerik Atoll, estimated by Sondhaus, was based on the assumption of a constant rate-of-rise of exposure rate. The exposure-rate datum used to indicate cloud passage was the offecale reading of $>100 \mathrm{mR} \mathrm{h}^{-1}$ at 7 hours and 22 minutes post-detonation $270 \mathrm{~km}$ (170 miles) away from Bikini Atoll. Estimates of fallout duration time by Peterson, Sondhaus, and Dunning and those estimated by us are tabulated in Table 3 for comparison.

Sifo Island, Ailingnae Atoll, was the same distance from the detonation site as the Japanese vessel contaminated by Bikini ash (BRAVO fallout). Bikini ash was observed to fall for 5 hours (Ts55). Bikini ash granule size was visible to the eye (Su56), which at this location was consistent with reports that fal1out was visible at Rongelap, Rongerik, and Ailingnae. Visual obgervations of

Table 3

Duration of Yallout, Hours

\begin{tabular}{|c|c|c|c|c|c|}
\hline $\begin{array}{l}\text { Location } \\
\text { of } \\
\text { People }\end{array}$ & $\begin{array}{c}\text { Distance } \\
\text { From the } \\
\text { Detonation } \\
\text { Site, } \mathrm{km}\end{array}$ & $\begin{array}{l}\text { Faîlout } \\
\text { Duration } \\
\text { Estimated } \\
\text { by Sondhaus } \\
1955 \\
\text { (So55) }\end{array}$ & $\begin{array}{l}\text { Fallout } \\
\text { Duration } \\
\text { Estimated } \\
\text { by Dunning } \\
1957 \\
\text { (JCAE57) }\end{array}$ & $\begin{array}{l}\text { Fallout } \\
\text { Duration } \\
\text { Estineted } \\
\text { by Peterson } \\
1981 \\
\text { (Pe81) }\end{array}$ & $\begin{array}{l}\text { Fallout } \\
\text { Duration } \\
\text { Eatinated } \\
\text { Here } \\
1984 \\
\text { (This Report) }\end{array}$ \\
\hline $\begin{array}{l}\text { Ailingnae } \\
\text { Ronge lap } \\
\text { Rongerik } \\
\text { Utirik }\end{array}$ & $\begin{array}{l}150 \\
210 \\
270 \\
570\end{array}$ & $\begin{array}{l}12 \\
12 \\
12 \\
12\end{array}$ & $\begin{array}{l}5.5 \\
5.5 \\
- \\
17\end{array}$ & $\begin{array}{r}10 \\
19 \\
17 \\
3\end{array}$ & $\begin{array}{r}5 \\
7 \\
9 \\
19\end{array}$ \\
\hline
\end{tabular}


fallout arrival and cessation time were reported by many persons at each of these locations (Sh57, Ts55), except Utirik, and were in reasonable agreewent with Dunning's values (see Table 3). On the basis of distance vo granule-size extrapolations and meteorological considerations, we also conclude that fallout would not have been visible at Utirik.

On Rongerik, a set of film badges was present and exposure results were obtained (So55). Survey instrument readings and the film badge results led Sondhaus to postulate total gama exposures, from the time fallout began up to the time of evacuation, of $0.027,0.022$, and $0.018 \mathrm{C} \mathrm{kg}^{-1}(106,86$, and $70 \mathrm{R})$. These values were based on three assumed fallout durations of 8, 12, and 16 hours, respectively. One film badge that remained outdoors at Rongerik gave a reading of $0.025 \mathrm{C} \mathrm{kg}^{-1}(98 \mathrm{R})$. This total exposure from the time of fallout to evacuation corresponded to a fallout duration of 9.6 hours, which compares closely to the 9-hour value derived from fitting visual observations of fallout duration with distance from the detonation site (see Section II.D of this report). For whole-body dose estimates, Sondhaus appears to have assumed a 12-hour duration for all locations in order to conform to "constant fallout." The definition of "constant fallout" was not clear. Sondhaus also writes that "fallout probably would not be uniformly heavy throughout, the first portion being the most intense and the balance decreasing with time" (Cr56).

4. Rate-of-Rise of Exposure Rate. The rate at which exposure rate rises to the peak value has ail effect on estimates of whole-body dose. A rate-of-rise in exposure rate at Rongerik Atoll was estimated from monitoring instrument readings taken for one-half hour (So55). Additional rate-of-rise information was determined from results supplied by Peterson (Pe81). Exposure-rate contours from graphs provided by Peterson were evaluated at different times at the Rongerik 1ocation. A best fit of the results yielded an exponential rise in exposure rate. A comfarison of the two, measured rise versus predicted rise, indicated a wide discrepancy, the measured rise being much steeper. These results are tabulated in Table 4 .

It is not clear which exposure-rate measurements Peterson accepted for normalizing $h$ is results. It is clear that he accepted at least one measurement at some location because he estimated whole-body dose. If both the Peterson and the Sondhaus whole-body dose results are to converge on the results for the Rongerik exposure-rate survey, which was made 9 days post-detonation (OC68), then Sondhaus's estimate of whole-body dose would have to be greater than Peterson's estimate, not less. This is because Peterson required a much slower rate-of-rise in exposure rate than did Sondhaus.

5. Comparison of Airborne Activity Concentrations. Air activity concentrations at Rongelap and Sifo Island were computed from the meteorological results provided by Peterson for ${ }^{13}{ } I_{\text {and }}{ }^{133}{ }_{I}$ (Pe81). For comparison, results for air activity concentrations of ${ }^{131_{I}}$ and ${ }^{133}$ I were estimated from the Bikini ash composition and are tabulated in Table 5. The cumulated activity and the airborne activity concentrations determined by either method do not agree. In summary, the Peterson-based approach towards estimating thyroid dose requires further refinement in order to achieve correspondence with all available information regarding external exposure, exposure rate and activity concentrations in air. 
Table 4

Measured and Predicted Rate-of-Rise of Exposure Rate at Rongerik Atoll

\begin{tabular}{ccc}
\hline $\begin{array}{c}\text { Time } \\
\text { Post-Detonstion, } \\
\text { Hours }\end{array}$ & $\begin{array}{c}\text { Measured } \\
\text { Exposure } \\
\text { Rate } \\
\text { mR h }\end{array}$ & $\begin{array}{c}\text { Peterson's } \\
\text { Predicted } \\
\text { Exposure } \\
\text { Rate } \\
\text { mR } h^{-1 a}\end{array}$ \\
\hline 6.87 & 0.18 & 220 \\
6.01 & 0.70 & 240 \\
6.95 & 2.7 & 270 \\
7.04 & 3.6 & 330 \\
7.12 & 10.5 & 400 \\
7.20 & 30 & 480 \\
7.29 & 60 & 580 \\
7.37 & 100 & 700 \\
7 Change & & \\
During & & 320 \\
Half Hour & 55,000 & \\
\hline
\end{tabular}

aultiple by $2.58 \times 10^{-7}$ to obtain $\mathrm{C} \mathrm{kg}^{-1} \mathrm{~h}^{-1}$.

C. Radioiodine Surface Activity Based on Archival Soil Analyses for ${ }^{129}$ I

1. The Archival Soil Sample Collection. Surface soil samples were removed from Rongelap, Utirik, and other atolls in the Marshall Islands during the period 1954 to 1974 . They were taken at depths up to two inches. Samples were stored at the Univefgity of Washington's Applied Fisheries Laboratory. Soil samples tested for ${ }^{129}$ I were either midisland soils with hums, sandy soils from all parts of the island: black and white beach sands, grey powdery soils, randomly collected composites, or humus-seedy mixtures. Of the thousands of samples stored at the University, several hundred were identified for neutron activation analysis. Samples were packed and sent to Battelle Pacific Northwest Laboratory and analyzed by Brauer (Br80).

${ }_{125}{ }^{2}$ is Analygis of Samples. Soil samples were analyzed for ${ }^{127} \mathrm{I},{ }^{129} \mathrm{I}$, $125 \mathrm{Sb}$, $137 \mathrm{CB}, 155 \overline{\mathrm{Eu} \text {, and }} 60 \mathrm{Co}$. The methods for neutron activation analysis were described by Brauer ( $3 r 74$ ) and Keisch (Ke65). Iodine was separated from soils according to the method of Studier (St62). Once separated, the iodine was irradiated with neutrons in a nuclear reactor, purified to reduce levels of interfering nuclides, and assayed using gama spectroscopy (Br80). For quality control, comparison samples containing known amounts of $125 \mathrm{I}, 127_{I}$, and $129 \mathrm{I}$ 
Table 5

Air Activity Concentrations

\begin{tabular}{|c|c|c|}
\hline & $\begin{array}{c}\text { Peterson's Results, } \\
\mu \mathrm{Ci}_{\mathrm{i}} \mathrm{cm}^{-3 a \mathrm{a}}\end{array}$ & $\begin{array}{l}\text { Bikini Ash Results, } \\
\quad \mu \mathrm{Ci} \mathrm{cm}^{-3}\end{array}$ \\
\hline $\begin{array}{l}\text { Time Post- } \\
\text { BRAVO, h }\end{array}$ & $131_{I}$ & $131_{I}$ \\
\hline
\end{tabular}

Ronge lap Island

$\begin{array}{rllll}5 & 2 \times 10^{-10} & 7 \times 10^{-9} & 1 \times 10^{-7} & 3 \times 10^{-6} \\ 7 & 7 \times 10^{-9} & 2 \times 10^{-7} & 3 \times 10^{-8} & 7 \times 10^{-7} \\ 10 & 4 \times 10^{-7} & 3 \times 10^{-6} & 5 \times 10^{-10} & 9 \times 10^{-9} \\ 14 & 2 \times 10^{-9} & 4 \times 10^{-8} & - & - \\ 17 & 3 \times 10^{-10} & 7 \times 10^{-9} & - & -\end{array}$

Cumulated

Activity

Concentration,

Ci $s \mathrm{~m}^{-3}$

$4.0 \times 10^{-3 b} \quad 1.0 \times 10^{-1} \quad 1.4 \times 10^{-3} \quad 3.3 \times 10^{-2}$

Sifo IsIand

$\begin{array}{rllll}3 & 4 \times 10^{-13} & 1 \times 10^{-11} & 8 \times 10^{-9} & 2 \times 10^{-7} \\ 5 & 5 \times 10^{-10} & 1 \times 10^{-6} & 4 \times 10^{-10} & 1 \times 10^{-8} \\ 7 & 2 \times 10^{-8} & 5 \times 10^{-8} & 1 \times 10^{-11} & 3 \times 10^{-10} \\ 12 & 5 \times 10^{-9} & 1 \times 10^{-7} & - & -\end{array}$

Cumulated

Activity

Concentration,

Ci $\mathrm{m}^{-3} \quad 6.0 \times 10^{-4 b} \quad 1.8 \times 10^{-2} \quad 6.9 \times 10^{-5} \quad 6.9 \times 10^{-3}$

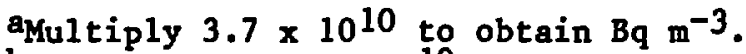

bultiply by $3.7 \times 10^{10}$ to obtain Bq $\mathrm{m}^{-3}$.

were irradiated with each set of iodine samples isolated from Marshall Islands' soils (Br80).

The number of initial comparison atoms and the resulting comparison activity were used to determine a production ratio. The production ratio was applied to the soil sample activity and the number of atoms of activated nuclide 
per gram of soil was estimated. Corrections to the soil activity were made on the basis of results for soil sample blanks, comparison sample blarks, and method yie1d.

A listing of the gamma-ray spectroscopy results and ${ }^{129}$ I results for soil samples is shown in Table 6 . The earliest surface soils dated back to 1955 about one and one-half years post-detonation of BRAVO. The ${ }^{60} \mathrm{Co}, 137 \mathrm{Cs}$, and $155_{\mathrm{Eu}}$ activities per gram of soil appeared to have declined slowly over the years, thile ${ }^{129} \mathrm{I}$ soil results declined at a much nore rapid rate. Individual counting errors were normally less than $5 \%$, although a few samples approached $20 \%$.

3. Estimate of Initial Surface Activity. Positive ${ }^{125} \mathrm{gb}$ results (see Table 6) were too sparse for inferences to be drawn. For ${ }^{129} \mathrm{I}$, results were plentiful and, therefore, a least squares fitting was performed on results for nuclide soil activity per unit mass of dry soil vs days post-detonation using linear, exponential, logarithmic, and power function models. Sample results varied from their best-fit value by as much as a factor of 9 and by an average factor of 2.5 over the period 1955 to 1977.

The best-fitting function was determined from a comparison of the co-efficient of determination for each mode1. Functions used with 129 I results for Rongelap soil were plotted in Figure 3. Only the 1955 to 1957 results were plotted to illustrate the following points. For ${ }^{129}$ I soil results, the bestfitting function was exponential. Al1 four fitting functions were generally useful in predicting soil activity per gram at times after 600 days post-BRAvo for all nuclides. A significant divergence between functions occurs during the period severa 1 hours out to one year post-BRAVo. For example, at 0.5 day the difference between the exponential and power function estimate spans 5 orders of magnitude for ${ }^{129}$ I.

for ${ }^{129} \mathrm{I}$. The exponential fit of the ${ }^{129} \mathrm{I}$ soil results at Rongelap led us to estimate a mean residence time in surface soil of about 5.4 years. The descriptive on these samples indicated that they were soils originally located at depths no greater than $5 \mathrm{~cm}$ ( 2 in.) beneath the surface.

4. Ratio of Nuclide Activity to Total Fallout Activity in Archiva1 Soils. The ratio of 129 activity to total fallout activity would help to determine whether the archival soil anaylsis for radioiodine corresponded to other measured or hypothetical ratios. The surface-soil activity of each nuclide measured by 3 rauer was estimated for 0.5 and 1.5 days post-detonation. These were the assumed times of cessation of fallout at Rongelap and Utirik, respectively. The value for the nuclide activity per unit mass of soil at the cessation of fallout was estimated from the best fit of archival soil results. For ${ }^{129} \mathrm{I}$, the estimate was recorded in Table 7 , column $A$.

At Rongelap, the total fallout activity per unit soil, based on four soil samples taken Karch 8, 1954 (OC68), was $3.0 \times 10^{5} \pm 4.1 \times 10^{5} \mathrm{~Bq}^{-1}(8.2$ $\pm 11 \mu \mathrm{Ci}^{-1}$ ) at 0.5 day. The total fallout activity per unit mass of Utirik soil was $11 \%$ of the Rongelap result based on a ratio of exposure rate at the two 
Table 6

Soil Sample Results for Rongelap and Utirik Islands

\begin{tabular}{|c|c|c|c|c|c|c|}
\hline \multirow{2}{*}{$\begin{array}{c}\text { Sample } \\
\text { Collection } \\
\text { Date }\end{array}$} & \multirow[b]{2}{*}{$\begin{array}{l}\text { Days Post- } \\
\text { Detonation }\end{array}$} & \multicolumn{5}{|c|}{ Rongelap, $\mathrm{pCi} \mathrm{g}^{-1 \mathrm{a}}$} \\
\hline & & ${ }^{60} \mathrm{Co}$ & $125_{\mathrm{sb}}$ & ${ }^{129} I$ & ${ }^{137} \mathrm{Cs}$ & ${ }^{155} \mathrm{Eu}$ \\
\hline $\begin{array}{r}10-22-55 \\
10-22-55 \\
10-22-55 \\
12-5-55 \\
7-23-56 \\
7-23-56 \\
7-17-57 \\
3-6-58 \\
3-6-58 \\
8-20-58 \\
11-29-74 \\
11-29-74 \\
12-2-74 \\
4-3-76 \\
4-3-76 \\
9-27-76 \\
5-10-77 \\
5-10-77 \\
10-18-77 \\
10-18-77 \\
10-18-77 \\
10-19-77 \\
10-19-77 \\
10-19-77\end{array}$ & $\begin{array}{r}600 \\
600 \\
600 \\
644 \\
875 \\
875 \\
1234 \\
1466 \\
1466 \\
1633 \\
7578 \\
7578 \\
7581 \\
8069 \\
8069 \\
8246 \\
8471 \\
8471 \\
8632 \\
8632 \\
8632 \\
8633 \\
8633 \\
8633\end{array}$ & $\begin{array}{c}2 . \\
2.0 \times 10^{-1} \\
- \\
2.1 \times 10^{-1} \\
2.3 \times 10^{-1} \\
- \\
3.7 \times 10^{-1} \\
4.3 \times 10^{0} \\
8.6 \times 10^{-1} \\
1.1 \times 10^{1} \\
2.6 \times 10^{-1} \\
2.2 \times 10^{-1} \\
1.9 \times 10^{0} \\
5.1 \times 10^{-1} \\
- \\
9.8 \times 10^{-1} \\
4.4 \times 10^{-1} \\
7.7 \times 10^{-1} \\
1.9 \times 10^{-1} \\
2.9 \times 10^{-1} \\
- \\
7.7 \times 10^{-2} \\
1.1 \times 10^{-1} \\
3.2 \times 10^{-1}\end{array}$ & $\begin{array}{c}- \\
- \\
- \\
- \\
- \\
- \\
1.0 \times 10^{-1} \\
- \\
- \\
2.7 \times 10^{0} \\
- \\
- \\
7.0 \times 10^{-1} \\
- \\
- \\
- \\
- \\
- \\
- \\
- \\
- \\
- \\
- \\
-\end{array}$ & $\begin{array}{l}1.1 \times 10^{-} \\
8.5 \times 10^{-3} \\
9.4 \times 10^{-4} \\
5.8 \times 10^{-3} \\
7.6 \times 10^{-4} \\
4.2 \times 10^{-4} \\
1.5 \times 10^{-3} \\
6.7 \times 10^{-4} \\
1.1 \times 10^{-4} \\
3.5 \times 10^{-3} \\
1.6 \times 10^{-5} \\
7.2 \times 10^{-5} \\
2.9 \times 10^{-4} \\
6.5 \times 10^{-5} \\
1.6 \times 10^{-5} \\
8.0 \times 10^{-5} \\
4.6 \times 10^{-5} \\
4.7 \times 10^{-5} \\
1.6 \times 10^{-5} \\
8.5 \times 10^{-6} \\
2.0 \times 10^{-5} \\
2.5 \times 10^{-5} \\
1.7 \times 10^{-5} \\
2.0 \times 10^{-5}\end{array}$ & $\begin{array}{c}1.4 \times 10^{0} \\
3.5 \times 10^{0} \\
- \\
2.4 \times 10^{0} \\
2.2 \times 10^{1} \\
7.0 \times 10^{0} \\
1.8 \times 10^{1} \\
3.8 \times 10^{2} \\
2.5 \times 10^{1} \\
5.0 \times 10^{1} \\
3.1 \times 10^{1} \\
3.5 \times 10^{1} \\
6.3 \times 10^{1} \\
7.2 \times 10^{0} \\
5.1 \times 10^{0} \\
1.7 \times 10^{1} \\
1.6 \times 10^{1} \\
9.2 \times 10^{0} \\
5.3 \times 10^{0} \\
3.7 \times 10^{0} \\
6.3 \times 10^{0} \\
2.3 \times 10^{0} \\
6.9 \times 10^{0} \\
7.4 \times 10^{0}\end{array}$ & $\begin{array}{c}2.7 \times 10^{-1} \\
1.2 \times 10^{-3} \\
2.0 \times 10^{-1} \\
3.0 \times 10^{-1} \\
- \\
- \\
1.0 \times 10^{1} \\
1.7 \times 10^{0} \\
3.4 \times 10^{1} \\
6.2 \times 10^{-1} \\
6.0 \times 10^{-1} \\
7.5 \times 10^{0} \\
- \\
- \\
2.3 \times 10^{0} \\
4.1 \times 10^{-1} \\
8.0 \times 10^{-1} \\
2.1 \times 10^{-1} \\
- \\
- \\
- \\
2.2 \times 10^{-1} \\
2.6 \times 10^{-1}\end{array}$ \\
\hline
\end{tabular}


Table 6 (Cont'd)

\begin{tabular}{|c|c|c|c|c|c|c|}
\hline \multirow{2}{*}{$\begin{array}{l}\text { Sample } \\
\text { Collection } \\
\text { Date }\end{array}$} & \multirow{2}{*}{$\begin{array}{l}\text { Days Post- } \\
\text { Detonation }\end{array}$} & \multicolumn{5}{|c|}{ Utirik, pCi $\mathrm{g}^{-1 \mathrm{a}}$} \\
\hline & & ${ }^{60}$ Co & $125 \mathrm{Sb}$ & ${ }^{129} I$ & ${ }^{137} \mathrm{Cs}$ & ${ }^{155_{\mathrm{Eu}}}$ \\
\hline $\begin{array}{r}12-3-55 \\
12-3-55 \\
11-26-74 \\
11-26-74 \\
11-26-74 \\
9-21-76 \\
9-21-76\end{array}$ & $\begin{array}{r}642 \\
642 \\
7575 \\
7575 \\
7575 \\
8240 \\
8240\end{array}$ & $\begin{array}{c}1.9 \times 10^{-1} \\
- \\
1.6 \times 10^{-1} \\
2.0 \times 10^{-1} \\
9.4 \times 10^{-2} \\
1.8 \times 10^{-1} \\
1.6 \times 10^{-1}\end{array}$ & $\begin{array}{l}- \\
- \\
- \\
- \\
-\end{array}$ & $\begin{array}{l}1.6 \times 10^{-4} \\
3.5 \times 10^{-5} \\
4.0 \times 10^{-3} \\
3.7 \times 10^{-5} \\
5.4 \times 10^{-4} \\
2.3 \times 10^{-5} \\
1.6 \times 10^{-5}\end{array}$ & $\begin{array}{c}1.8 \times 10^{0} \\
- \\
2.2 \times 10^{0} \\
1.4 \times 10^{0} \\
2.2 \times 10^{0} \\
2.8 \times 10^{0} \\
7.8 \times 10^{-1}\end{array}$ & $\begin{array}{c}- \\
- \\
2.5 \times 10^{-1} \\
- \\
2.4 \times 10^{-1} \\
- \\
-\end{array}$ \\
\hline $\begin{array}{r}5-8-77 \\
10-13-77 \\
10-13-77 \\
10-13-77\end{array}$ & $\begin{array}{l}8469 \\
8627 \\
8627 \\
8627\end{array}$ & $\begin{array}{c}- \\
1.1 \times 10^{-1} \\
1.3 \times 10^{-1} \\
-\end{array}$ & $\begin{array}{l}- \\
- \\
-\end{array}$ & $\begin{array}{l}1.7 \times 10^{-5} \\
9.6 \times 10^{-6} \\
2.0 \times 10^{-5} \\
5.7 \times 10^{-6}\end{array}$ & $\begin{array}{l}6.7 \times 10^{-1} \\
1.2 \times 10^{0} \\
1.6 \times 10^{0} \\
9.0 \times 10^{-1}\end{array}$ & $\begin{array}{l}- \\
- \\
-\end{array}$ \\
\hline $\begin{array}{l}10-14-77 \\
10-14-77 \\
10-14-77\end{array}$ & $\begin{array}{l}8628 \\
8628 \\
8628\end{array}$ & $\begin{array}{l}- \\
8.6 \times 10^{-2} \\
1.3 \times 10^{-1}\end{array}$ & $\begin{array}{l}- \\
-\end{array}$ & $\begin{array}{l}1.1 \times 10^{-5} \\
2.3 \times 10^{-5} \\
1.1 \times 10^{-5}\end{array}$ & $\begin{array}{l}7.0 \times 10^{-1} \\
3.2 \times 10^{0} \\
1.6 \times 10^{0}\end{array}$ & $\begin{array}{l}- \\
-\end{array}$ \\
\hline
\end{tabular}

ayultiply by 0.037 to obtain $\mathrm{Bq} \mathrm{g}^{-1}$.

islands after all of the fallout was on the ground. The fallout decay exponent was assumed by us to be -1.2 in order to extrapolate activity present on March 8, 1954, back to activity present on March 1, 1954. The exponent, -1.2 , is the theoretical value for mixed fission products and is considered suitable for estimating the correspondence of ${ }^{129}{ }_{I}$ soil results with other measurenents. At Utirik, the total fallout activity per unit mass of soil was $7.8 \times 10^{3} \mathrm{~Bq} \mathrm{~g}^{-1}$ $\left(0.21 \mu \mathrm{Ci}^{-1}\right)$ at 1.5 days post-detonation.

The ratio of nuclide activity per unit mass of soil to the total beta activity per unit mass of soil was tabulated in Table 7, colum B. This ratio applies at the times of cessation of fallout. The values in colum $B$ were compared to values estimated from measurements on actual BRAVo fallout and those estimated by calculation using hypothetical undisturbed fission product yield data. These estimates for BRAVo fallout activity ratios and those for hypothetical undisturbed fission products were determined as follows.

5. The Ratio of Nuclide Activity to Fission Product Activity for Thermonuclear Fission. Nuclide activity relative to total fission product activity vas estimated from data on thermonuclear fission of ${ }^{238} \mathrm{U}$ given by Crocker (Cr65). Total activity values given by Crocker do not account for chemical and physical deletion or enhancement of fission products, production of activation products, or production of transuranics. Total activity per 10,000 fissions at 0.5 and 


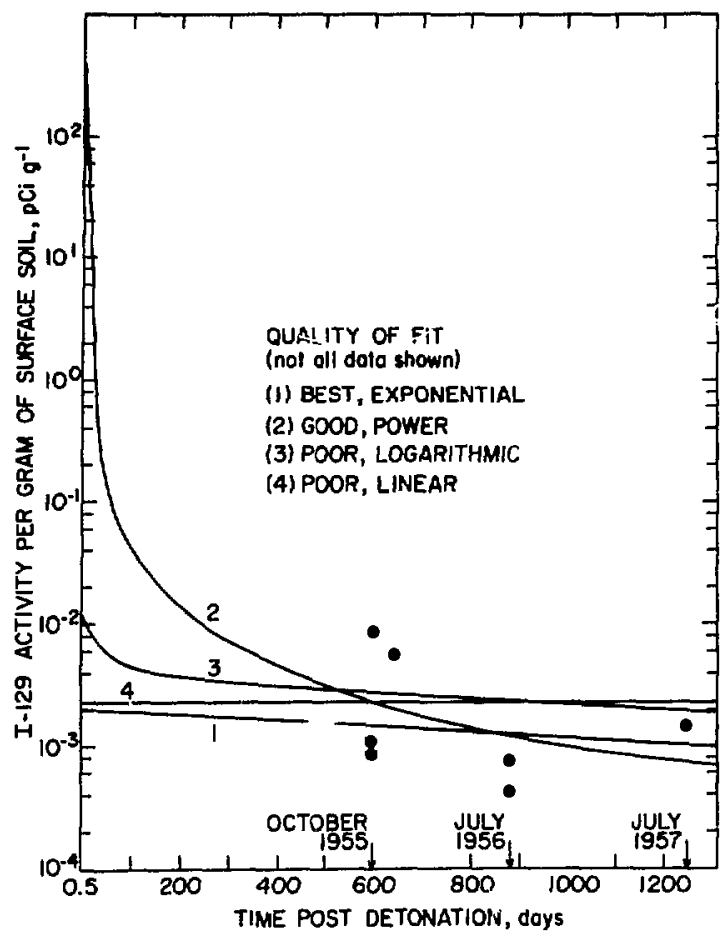

Figure 3. Curve fit of archival soil results.

1.5 days was taken from Table 3 of Crocker's report (Cr65). Individual nuclide activities were calculated by Crocker's methods and the original input data used by him (Cr63). The values for the hypothetical ratio of nuclide activity relative to total fission product activity are tabulated in Table 7 , column $\mathbb{E}$.

6. The Ratio of Nuclide Activity to Total Activity for Bikini Ash. Bikini ash was the name given by the Japanese for actual fallout from BRAvo (Is56). Estimates of Bikini ash activity per unit mass of soil were calculated from results for activity per unit area given in Table 13 of this report. Table 13 was devised by normalizing Bikini ash measurements to external exposure-rate measurements. Using the nuclide composition of Bikini ash, a fallout decay exponent specific for BRAVO fallout was developed (see Section IID.1.e) and was -1.4. Values for individual nuclide and total activity were developed for the surfaces of Rongelap, Utirik and Sifo Islands for different points in titue. Bikini ash activity per unit mass of soil estimates were tabulated in Table 7 , colum $C$. The times are 1.5 days post detonation at Utirik and 0.5 days post detonation at Rongelap.

To estimate specific activity from areal activity, approximately $65,000 \mathrm{~g} / \mathrm{m}^{2}$ of soil were assumed to be present in the top $5 \mathrm{~cm}$ (2 in.) of soil. This value comes from a conversion factor of $6000 \mathrm{~g} / \mathrm{ft}^{2}$ proposed by the survey team which visited Rongelap on March 8, 1954 (OC68). A bulk soil-humus density of $1.3 \mathrm{~g} / \mathrm{cm}^{3}$ in the top $5 \mathrm{~cm}$ (2 in.) of soil could be assumed to estimate a similar conversion factor. 
Table 7

Archival Soil Reaults Compared to Thernonuclenr Fission and Rikini Aoh Results

\begin{tabular}{|c|c|c|c|c|c|c|c|c|}
\hline $\begin{array}{l}\text { Muclide } \\
\text { (F of Samples) } \\
\text { Rongelap }\end{array}$ & $\begin{array}{l}\text { Archival } \\
\text { Soil } \\
\text { velue at } \\
0.5 \text { Day. } \\
\text { PCi } \mathrm{g}^{-1 .} \\
\text { A }\end{array}$ & $\begin{array}{c}\text { Ratio of A } \\
\text { to Measured } \\
\text { Grose Beta } \\
\text { Activity } \\
\text { in Soil } \\
\text { B }\end{array}$ & $\begin{array}{l}\text { Eikini } \\
\text { Ash Value } \\
\text { at } 0.5 \text { Day } \\
\text { PCi g-ia } \\
\text { C }\end{array}$ & $\begin{array}{c}\text { Ratio of C } \\
\text { to Total } \\
\text { Bikini Ash } \\
\text { Activity } \\
\text { D }\end{array}$ & $\begin{array}{l}\text { Hypothetical Ratio of } \\
\text { Muclide Activity to } \\
\text { Total Activity for } \\
\text { Thermonuclear } \\
\text { Fisaion of } 238 \mathrm{U} \\
\text { E }\end{array}$ & $\begin{array}{c}\text { Soil Result } \\
\text { Compred to } \\
\text { Thermonuclear Fission } \\
\text { Result } \\
\text { B/E }\end{array}$ & $\begin{array}{c}\text { Soil } \\
\text { Result Compared to } \\
\text { Bikini Ash } \\
\text { Result } \\
\text { B/D }\end{array}$ & $\begin{array}{c}\text { Bikini Aeh Reeult } \\
\text { Compared to } \\
\text { Therwonuclear Fission } \\
\text { Reault } \\
\text { D/E }\end{array}$ \\
\hline \multicolumn{9}{|c|}{ Rongel ap } \\
\hline $\begin{array}{l}125 s i \\
(n-13)\end{array}$ & $1.5 \times 10^{0}$ & $1.8 \times 10^{-7}$ & $5.4 \times 10^{1}$ & $3.5 \times 10^{-6}$ & $4.6 \times 10^{-6}$ & 0.039 & 0.051 & 0.76 \\
\hline $\begin{array}{l}129_{I} \\
(n=24)\end{array}$ & $2.1 \times 10^{-3 b}$ & $2.6 \times 10^{-10 b}$ & $7.0 \times 10^{-5}$ & $4.5 \times 10^{-12}$ & $3.5 \times 10^{-12}$ & $74 . \mathrm{b}$ & $58 . \mathrm{b}$ & 1.3 \\
\hline $\begin{array}{l}137 \mathrm{ca} \\
(\mathrm{n}=23)\end{array}$ & $6.2 \times 10^{1}$ & $7.6 \times 10^{-6}$ & $1.1 \times 10^{2}$ & $7.1 \times 10^{-6}$ & $5.5 \times 10^{-6}$ & 1.4 & 1.1 & 1.3 \\
\hline $\begin{array}{l}155 \mathrm{Eu} \\
(\mathrm{x}=16)\end{array}$ & $6.8 \times 10^{0}$ & $8.3 \times 10^{-7}$ & $1.1 \times 10^{1}$ & $7.1 \times 10^{-7}$ & $9.6 \times 10^{-7}$ & 0.87 & 1.2 & 0.74 \\
\hline \multicolumn{9}{|c|}{ Utirik $^{c}$} \\
\hline $\begin{array}{l}{ }^{129} I \\
(n=14)\end{array}$ & $1.4 \times 10^{-4 b}$ & $6.7 \times 10^{-10 b}$ & $7.7 \times 10^{-6}$ & $1.8 \times 10^{-11}$ & $1.3 \times 10^{-11}$ & $52 . \mathrm{b}$ & $37 . \mathrm{b}$ & 1.4 \\
\hline $\begin{array}{l}{ }^{137} \mathrm{cs} \\
(\mathrm{n}-13)\end{array}$ & $2.0 \times 10^{0}$ & $9.5 \times 10^{-6}$ & $1.2 \times 10^{1}$ & $2.7 \times 10^{-5}$ & $2.1 \times 10^{-5}$ & 0.45 & 0.35 & 1.3 \\
\hline${ }_{(n=2)}^{155}$ & $2.5 \times 10^{-1}$ & $1.2 \times 10^{-6}$ & $1.2 \times 10^{0}$ & $2.7 \times 10^{-6}$ & $3.6 \times 10^{-6}$ & 0.33 & 0.44 & 0.75 \\
\hline
\end{tabular}

Wultiply by 0.037 to obtain $\mathrm{Bq} \mathrm{g}^{-1}$.

byalue have atandard deviation of $\pm 900 \%$.

cvalues at 1.5 daye for Utirik results. 
The ratio of nuclide activity to total activity was estinated from all of the activities listed in Table 13. The total activity in Bikini ash included the contribution of transuranics and activation products and was somewh different in composition from hypothetical and undisturbed fission products.

On day 0.5 at Rongelap, a total activity per unit mass of soil of 5.5 $\times 10^{5} \mathrm{~Bq}^{-1}\left(15 \mu \mathrm{Ci} \mathrm{g}^{-1}\right)$ was estimated from Bikini ash. A good portion of the activity was due to the decay of ${ }^{239} \mathrm{~Np}$ and $237 \mathrm{~V}$ and other short-lived nuclides. The presence of short-lived activation and transuranic nuclides influenced the overall fallout decay exponent. A value for total activity per unit mass of soil of $1.6 \times 10^{4} \mathrm{~Bq} \mathrm{~g}^{-1}\left(0.44 \mu \mathrm{Ci} \mathrm{g}^{-1}\right)$ at 1.5 days at Utirik was estimated. The ratio of nuclide activity to total activity based on Bikini ash is tabulated in Table 7, column D.

7. Comparison of Archival Soil Measurements to Thermonuclear Fission Data and Bikini Ash Estimates. The archival soil results were conpared using the ratiog of nuclide activity to total activity (Table 7 , colums $B / E, D / E$, and $B / D$ ). For ${ }^{125} \mathrm{Sb}$ the ratios were not similar; however, soil sample-size was small. For ${ }^{155} \mathrm{Eu}$ and ${ }^{137} \mathrm{Cs}$, results were in accord at both Rongelap and Utirik. The archiva1 soil results for ${ }^{129} \mathrm{I}$ at Rongelap and Utirik were distinctly different from the hypothetical thermonuclear-fission results and Bikini Ash results.

In order to estimate the significance of the wide differences for ${ }^{129} I$ results, the standard deviations of the activity ratios were determined. The standard deviation of the archival soil best-fit value at 0.5 day (Table 7, column A) was approximated by linear regression methods (Be69). The archival soil result for ${ }^{129} \mathrm{I}$ at Rongelap was $7.8 \times 10^{-5} \pm 6.7 \times 10^{-4} \mathrm{~Bq} \mathrm{~g}\left(2.1 \times 10^{-3} \pm 1.8\right.$ $x 10^{-2} \mathrm{pCi} \mathrm{g}^{-1}$ ) at the time of fallout cessation. The standard deviation of the four measurements of total activity per unit mass of soil on March 8, 1954, was $134 \%$ of the mean (OC68). The mean and standard deviation of the archival soil activity ratio (Table 7 , colum $B$ ) was estimated to be $2.6 \times 10^{-10} \pm 2.35 \times$ $10^{-9}$. Thus it is concluded that a significant difference between this ratio and the other two cannot be determined due to the large standard deviation. Columns $B / E$ and $B / D$ are also uncertain for ${ }^{129} \mathrm{I}$.

Errors in the thermonuclear fission product activity ratio for ${ }^{129}$ I (Table 7, colum E) were due to errors in independent yield data and half-life measurements and were estimated by Crocker to be on the order of $10 \%(\mathrm{Cr} 65)$. The mean and standard deviation of this hypothetical ratio was estimated to be 3.5 $\times 10^{-12} \pm 5.0 \times 10^{-13}$.

A wide divergence between the measured activity ratio and the hypothetical activity ratio was possible. It may have been due to chemical and physical phenomena experienced by nuclides in the 129 mass chain at different times postdetonation. Enrichment by a maximum factor of 100 has been noted occasionally (Fr61).

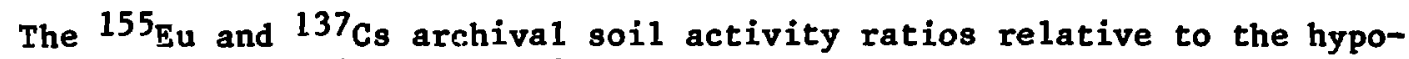
thetical ratio and the Bikini Ash ratio ranged between 0.87 and 1.4 for Rongelap soils and 0.33 and 0.45 for Utirik soils. These ratios were within acceptable limits of statistical uncertainty and are comparable. The Bikini Ash activity 
ratios for ${ }^{129} \mathrm{I},{ }^{155} \mathrm{Eu}$, and ${ }^{137} \mathrm{Cs}$ were yery close to the hypothetical ratios estimated for thermonuclear fission of $238 \mathrm{U}$.

8. Estingtion of Radioiodine Activity per Unit Area Based on Soil Activity for 129 I. From the archival neasurements, the iodine isotope activity was estinated per unit area of soil at the cessation of fallout at Rongelap (see Table 8). The enrichment of the iodine isotopes was assuned to be the acme as for $129 \mathrm{I}$.

The total radioiodine soil activity per unit area, based on 129 content of archival soils from Rongelap, exceeded the estinated total activity of all radionuclides per unit area by a factor of 10 . The estimated total activity was based on four soil samples taken and measured for beta activity on March 8 , 1954 (OC68). The radioiodine soil activity per unit area, based on archival soils from Utirik, exceeded the estimated total soil activity per unit area by a factor of 7 . Because these archival soil based estinates were so mch greater than measured activity, the assumption could not be made that iodine isotopes mimicked the behavior of ${ }^{129} \mathrm{I}$, and thus the usefulness of archival soil measurements was limited.

The level of ${ }^{129}$ I in archival soil may be real, an artifact of the neutron activation technique, or the residue from other weapons tests occurring near the time of soil collection. Comparison of Bikini ash results to hypothetical results for ${ }^{129}$ I (Table 7, column D/E) leads one to believe that sone enrichment of ${ }^{129}$ I occurred but not to the extent indicated by our extrapolation of archival soil measurements (Table 7, column B/E). The level of activity of ${ }^{129} \mathrm{I}$ in Bikini ash was based on direct measurements of ${ }^{129}{ }_{\mathrm{Te}}$ and ${ }^{132} \mathrm{I}$ (Is56).

Table 8

Activity of Iodine Isotopes Based on Archival Soil Resulta

\begin{tabular}{|c|c|c|}
\hline $\begin{array}{l}\text { Iodine } \\
\text { Isotope }\end{array}$ & $\begin{array}{c}\text { Activity per Unit } \\
\text { Area at Rongelap } \\
\text { at } 0.5 \text { Day, } \\
\mu C i \mathrm{~m}^{-2 \mathrm{a}}\end{array}$ & $\begin{array}{l}\text { Activity per Unit } \\
\text { Area at Utirik } \\
\text { at } 1.5 \text { Days, } \\
\mu C i \mathrm{~m}^{-2 \mathrm{a}}\end{array}$ \\
\hline $\begin{array}{l}{ }^{129} I \\
131 \\
132 \\
133 I \\
134 I \\
135 I \\
\text { Total }\end{array}$ & $\begin{array}{l}1.4 \times 10^{-4} \\
1.9 \times 10^{5} \\
5.8 \times 10^{5} \\
2.0 \times 10^{6} \\
2.0 \times 10^{4} \\
2.5 \times 10^{6} \\
5.3 \times 10^{6}\end{array}$ & $\begin{array}{l}9.0 \times 10^{-6} \\
9.2 \times 10^{3} \\
2.5 \times 10^{4} \\
4.9 \times 10^{4} \\
5.2 \times 10^{-6} \\
9.8 \times 10^{3} \\
9.3 \times 10^{4}\end{array}$ \\
\hline
\end{tabular}

a Hultiply by $3.7 \times 10^{4}$ to obtain Bq $\mathrm{m}^{-2}$. 
Enrichwent of ${ }^{129}$ I in Bikini ash could have occurred independently without enriching ${ }^{129}$ Te or ${ }^{132} \mathrm{I}$, with the result that an ${ }^{129} \mathrm{I}$ comparison between $\mathrm{B}$ ikini ash and archival soils was invalid. In conclusion, weasurements on archival soils for $155_{\mathrm{Eu}}$ and $137 \mathrm{Cs}$ were in good agreewent with Bikini ash and hypcthetical fesults. The level of ${ }^{129}$ I in archival soils does not equate with the level of ${ }^{129}$ I estimated by other methods nor does it equate with a reasonable extrapolation of the levels of other iodine isotopes.

D. Thyroid Absorbed-Dose Estimate Based on Bikini Ash

\section{Surface Activity and Exposure-Rate Estimateg}

a. The Nuclide Composition. Radiochemical analysis results for the BRAVO fallout are sumarized in Table 9 . Bikini ash fell on the Japanese fishing vessel, the 5 th Lucky Dragon, on the day of the test. Its gross beta activity was measured and normalized to day 26, and individual nuclide beta activity was identified and quantified by Japanese scientists (Ya56, Ts55). The percent of fallout beta activity, due to fission products present on day 26 after formation, is tabulated in Table 9. The hypothetical beta activity is based on a fallout composition unaltered due to chemical or physical mechanisms affecting certain fission product nuclides. This unaltered composition, which is referred to as unfractionated, was calculated from data given by Crocker (Cr65).

The comparison between Bikini ash beta activity and unfractionated fission product beta activity required conversion of the Yamatera and Tsuzuki data sets (Ya56, Ts55) into percent fission product beta activity. That is, we exclude the beta activity of the activation products $35 \mathrm{~s}, 45 \mathrm{Ca}$ and the transuranic nuclide $237_{\mathrm{U}}$ for comparison purposes. We assumed that $237_{\mathrm{U}}$, which represented $20 \%$ of the beta activity on day 26 in the Tsuzuki data, represented $20 \%$ of the beta activity in the Yamatera data.

The column in Table 9 headed "U-238TN Unfractionated \% Fission Product Beta Activity" represents the hypothetical percent of selected unfractionated fission products following thermonuclear neutron fission of $238 \mathrm{U}$. The data are applicable to day 26 post-detonation. The thermonuclear neutron energy spectrum and uranium target were chosen to represent the BRAVO device $(0 \mathrm{C68})$. The difference between percentages based on the Japanese measurements and those based on the hypothetical beta activity from thermonuclear fission represents differences between fractionated and unfractionated fallout.

As previously implied, the term fractionation indicated alterations of nuclide composition in fallout debris. The ratio of two nuclides in fallout was often used to describe fractionation quantitatively (Fr61). The denominator of the ratio was taken to be the activity of $95 \mathrm{zrNb}$ (Fr61). To quantify fractionation between two nuclides, the beta activity ratios were compared by Freiling (Fr61). He uses the term "degree of fractionation" to represent the range of variability of the nuclide ratio. The term "extent of fractionation" represented the portion of the total nuclide produced in the fallout cloud wich departed from the unfractionated ratio. 


\section{Table 9}

Measured BRAVO Fallout Composition and Unfractionated Composition on Day 26

\begin{tabular}{|c|c|c|c|c|c|}
\hline Nuclide (s) & $\begin{array}{l}\text { Yamatera } \\
\text { Data, } \\
\text { \% of Beta } \\
\text { Activity }\end{array}$ & $\begin{array}{l}\text { Yamatera } \\
\text { z Fission } \\
\text { Product Beta } \\
\text { Activity }\end{array}$ & $\begin{array}{l}\text { Tsuzuki } \\
\text { Data, } \\
\text { z of Beta } \\
\text { Activity }\end{array}$ & $\begin{array}{c}\text { Tsuzuki } \\
\text { z Fission } \\
\text { Product Beta } \\
\text { Activity }\end{array}$ & $\begin{array}{c}\text { U-238m } \\
\text { Unfractionated } \\
\text { z Fisaion } \\
\text { Product Beta } \\
\text { Activity }\end{array}$ \\
\hline 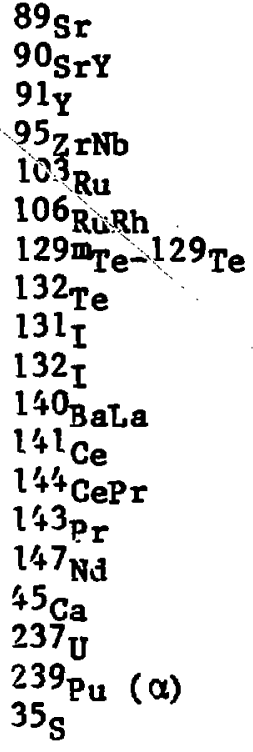 & $\begin{array}{c}1.6 \\
0.02 \\
a \\
9.8 \\
5.0 \\
1.4 \\
1.3 \\
1.0 \\
4.5 \\
1.0 \\
11.0 \\
9.7 \\
2.8 \\
a \\
a \\
a \\
a \\
a \\
a\end{array}$ & $\begin{array}{c}2.0 \\
0.025 \\
- \\
12.0 \\
6.3 \\
1.8 \\
1.6 \\
1.3 \\
5.6 \\
1.3 \\
14.0 \\
12.0 \\
3.5 \\
- \\
- \\
- \\
- \\
- \\
-\end{array}$ & $\begin{array}{l}1.0 \\
0.040 \\
8.0 \\
8.0 \\
\text { b } \\
\text { b } \\
\text { b } \\
\text { b } \\
b \\
\text { b } \\
11.0 \\
7.0 \\
4.0 \\
16.0 \\
9.0 \\
0.20 \\
20.0 \\
0.00040 \\
0.050\end{array}$ & $\begin{array}{c}1.3 \\
0.050 \\
10.0 \\
10.0 \\
c \\
c \\
c \\
c \\
c \\
c \\
14.0 \\
8.8 \\
5.0 \\
20.0 \\
11.0 \\
- \\
- \\
- \\
-\end{array}$ & $\begin{array}{l}4.2 \\
0.062 \\
4.1 \\
9.6 \\
8.5 \\
0.94 \\
0.42 \\
0.83 \\
6.1 \\
0.83 \\
23.0 \\
10.0 \\
2.9 \\
12.0 \\
5.3 \\
- \\
- \\
- \\
-\end{array}$ \\
\hline
\end{tabular}

$a_{51 \%}$ of total beta activity.

$b_{15 \%}$ of total beta activity.

$c_{197}$ of total fission product beta activity.

A review of the data in Table 9 indicated to us that the activity ratios for $132 \mathrm{Te}, 132 \mathrm{I}, 131_{\mathrm{I}}, 141_{\mathrm{Ce}}, 106 \mathrm{RuRh}$, $144 \mathrm{CeF}$ ( (their activity relative to measured 95 ZrNb beta activity) did not differ by a factor greater than about

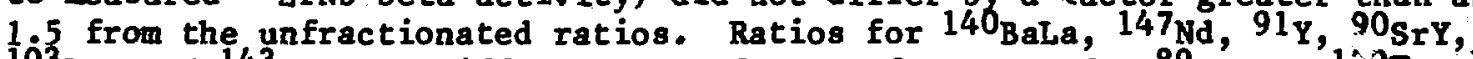
$103_{\mathrm{Ru}}$, and ${ }^{14} 3_{\mathrm{Pr}}$ were different by a factor of about 2 for ${ }^{89} \mathrm{Sr}$ and $129{ }^{\mathrm{Te}}-129 \mathrm{Te}$ by a factor of about 3 relative to the unfractionated ratios. The nuclides $91 \mathrm{Y}$, $106 \mathrm{RuRh}, 129 \mathrm{me}-129 \mathrm{Te}, 132 \mathrm{Te}, 132 \mathrm{I}, 144 \mathrm{CePr}, 143_{\mathrm{Pr}}$, and $147_{\mathrm{Nd}}$ were in greater abundance relative to unfractionated debris. 
Freiling (Fr61) indicated that the degree of fractionation from a surface burst could be significant. The extent of the fractionation throughout the debris was another variable he observed to be significant. Freiling emphasized the high degree of fractionation between nuclides classified as volatile and refractory for coral atoll surface bursts. Generalizations were made, to be used with much caution. Freiling indicated that, in general, fractionation would decrease as device yield decreased and would increase with depth, that is, air bursts would be less fractionated than surface bursts which would be less fractionated than subsurface bursts. From Freiling's studies, we cautiously expect that the high yield surface burst creating the BRAVo fallout caused a moderate-to-high degree of fractionation which occurred noderately to extensively throughout the debris.

For the coral surface burst, Freiling observed that the ratio of ${ }^{95} \mathrm{7r}$ to ${ }^{89} \mathrm{Sr}$ activity could be chosen as a representative measure of the overal1 degree of fractionation between refractory and volatile elements. This ratio had a value of 5 for a deep water surface burst of megaton range and a value of 100 for a coral surface burst (Fr61). The unfractionated value for this ratio, for day 26 post-detonation and for thermonuclear neutron fission of ${ }^{238} \mathrm{U}$, was calculated to be 1.6 from data given by Crocker (Cr65). From the average of Yamatera and Tsuzuki data, we calculated the ratio of ${ }^{95} \mathrm{Zr}$ activity to ${ }^{89} \mathrm{Sr}$ activity measured on day 26 to be 4.8 . This measured value for the degree of fractionation was characteristic of a deep water surface burst of the megaton range, moderately but not highly fractionated. This moderate fractionation probably occurred moderately to extensively throughout the fallout cloud because of the large yield and surface location of the device (Fr61).

The effect of fractionation on decay rate is very complex, and simple observation of overall radioactive decay does not yield significant information. Even so, the decay rates from widely distributed samples obtained out to 480 r.m (300 miles) from the BRAvo detonation site were similar. The decay rates from activity on different-size fallout granules collected at the same site were similar (0G68). These facts alone do not indicate that the same fractionation was common to all granule sizes. In fact, small granules traveled with the cloud for longer periods of time and possibly adsorbed more longer-lived nuclides than did the very large granules. In the analysis, we assume that the fractionation observed for Bikini ash granules was similar for granules at Rongelap, Sifo, and Utirik Islands. With the possible exception of Utirik Island, this assumption was considered valid owing to the proximity of Rongelap :- Sifo Islands to the 5 th Lucky Dragon.

b. The Decay of Fallout. The ganma and beta decay of the BRAVO radioactivity after the first 10 days post-detonation was measured by several researchers (e.g., Miller, Servis, Tomkins, Wilsey, and stetson, see 0c68). Decay data from measurements made between 0 and 10 days were not found in the literature. Fallout samples, taken weeks after the BRAvo event, were fron Bikini Atoll, Rongelap Atoll, the 5 th Lucky Dragon, and the surface of US Navy ships in the area. The measured decay exponent after two weeks was used by many researchers to extrapolate exposure rate back to times prior to sanple collection and in one case was used to estimate activity decline every hour postdetonation (Miller, 0C68). These extrapolations by Miller for the decay of fa11- 
out activity from several hours to a few weeks post-BRAvo apparently excluded the decay characteristics of non-fission-fragment nuclides. This would affect surface activity estimates which we derived from Bikini ash results ince these estimates relied in part on extrapolated decay rates. The estimated thyroid dose from internal sources would be affected by decay characteristics because it relied in part on these derived surface activity estimates.

In order to derive ground activity estimates at times close to BRAVO detonation and to derive external and internal thyroid dose, the gama- or beta-decay-rate decline over short periods of time was assuned to have followed the relationship

where

$$
x_{2}=x_{1}{\frac{t_{2}}{t_{1}}}^{m},
$$

$$
\begin{aligned}
& x_{1}=\text { gamma- or beta-decay rate at time } t_{1} \text {, and } \\
& x_{2}=\text { gamma- or beta-decay rate at time } t_{2} \text {. } \\
& m=\text { decay exponent. }
\end{aligned}
$$

In the early post-BRAvO period and for time intervals of a few hours, Miller's estimate of decay exponents may have departed significantly from the standard value used for planning fallout activity decline $(m=-1.2)$. His values for $m$ at different times post-detonation of BRAVO are listed in Table 10 . At short time intervals there was a departure from $m=-1.2$. However, the overall decay exponent calculated from Miller's declining activity results, for the interval one hour to sixty days post-detonation, was -1.2 . This was in agreement with the standard value used for decay of unfractionated fission products. Thus, it seemed to us that the impact on activity decline due to non-fission-fragment nuclides may not have been folded into Miller's extrapolation.

Further study was done to establish actual BRAvo activity and exposure-rate decline. Surveys performed by the radsafe team of the USS PHILIP, the ship dispatched to evacuate people from Rongelap Island, have recorded an exposure-rate level for Rongel ap village of $3.8 \times 10^{-4} \mathrm{C} \mathrm{kg}^{-1} \mathrm{~h}^{-1}\left(1+73 \mathrm{mR} \mathrm{h}^{-1}\right)$ average and $4.9 \times 10^{-4} \mathrm{C} \mathrm{kg}^{-1} \mathrm{~h}^{-1}\left(1900 \mathrm{mR} \mathrm{h}^{-1}\right)$ maximum at 2.2 days postdetonation (COMTASK GROUP 7.3 Disp 0208482 of March 1954, OC68). A similar but less precise statement of the exposure rate at the time of evacuation was given by Sharp (Sh57). In order to reconstruct the BRAVo exposure-rate decline prior to evacuation and not use the standard decay exponent, we derived additional information about the arrival time and nuclide composition of BRAVo fallout from Bikini ash measurements.

c. The Buildup of BRAvo Fallout on the Ground. The studies by Suito, Takiyama, and Uyeda (Su56) indicated that Bikini ash consisted of irregularly shaped white gramules. Bikini ash, taken from the deck of the 5 th Lucky Dragon, was deposited while the ship was located about $150 \mathrm{~km}$ ( 90 miles) from the detonation site (Ts55). Suito defined the mean volume diameter to be the dianeter corresponding to the mean volume. From the size and shape distributions, Suito determined the mean volume diameter of Bikini ash granules to be $320 \pm 70 \mu$ $\left(1.3 \times 10^{-2} \pm 2.8 \times 10^{-3} \mathrm{in} \cdot\right)$. The man mass of a gramile was 0.039 m $(8.7 \times$ $\left.10^{-9} \mathrm{lb}\right)$. The specific gravity was 2.4 , less than the specific gravity of 
Table 10

BRAvo Gamma or Beta Exponent

Indicated by Miller (0C68) for Fission Products

Time Post-Detonation,

$t_{1}$ to $t_{2}$

Decay Exponent,

(h)

m

$\begin{array}{rrr}1 \text { to } 2 & -1.4 \\ 2 \text { to } 3 & -1.2 \\ 3 \text { to } 6 & -.92 \\ 6 \text { to } 9 & -.81 \\ 9 \text { to } 12 & -.78 \\ 12 \text { to } 24 & -.82 \\ 24 \text { to } 48 & -1.0 \\ 48 \text { to } 96 & -1.2\end{array}$

$\mathrm{CaCO}_{3}, 2.7-2.9$. The granules were aggregates of smaller unit particles with shapes that varied from spindles to cubes to spheres. The size of these unit particles making up the granules varied from 0.1 to $3.0 \mu_{m}\left(4 \times 10^{-6}\right.$ to $1.2 \times$ $10^{-5}$ in.). It was suggested by Suito that Bikini ash was formed by evaporation of the coral reef to its constituent atoms and then by recrystallization of $\mathrm{Ca}$ with $\mathrm{H}_{2} \mathrm{O}$ and $\mathrm{CO}_{2}$ in the air (Su56).

The granule size distribution of Bikini ash was used to estimate the time over which the bulk of the activity fell on the fishing vessel. Most of the activity was carried by larger-volume granules, which fell at early times post-detonation (La65). The Bikini ash activity versus granule size distribution, $Z$ of total activity versus granule size, was plotted in Figure 4 . To construct this histogram, we assumed the activity of a granule to be proportional to the 3.5 power of its size. Lavrenchik summarized the results of many studies and concluded that the activity of a granule was proportainal to the 3rd or 4 th power of granule size (La56). He generalized that the activity and volume of the granule were proportional. The number of granules in each size class was reported by Suito for Bikini Ash (Su56). The size at median activity was $370 \mu \mathrm{m}$.

Our information regarding granule fall time as a function of granule size was derived from deposition models which were reviewed by Norment (No66). Four mode1s of fallout settling were presented. These models accounted for granule size and initial height of the granule. Granule fall times from various heights were derived by Norment who used the model results of Davies, Hedman, Hastings, or Ksanda. Although the complexity of each model varied, each accounted for the aerodynamic properties of irregularly shaped fallout granules. The granule fall time result versus granule size was recast by us using a power 


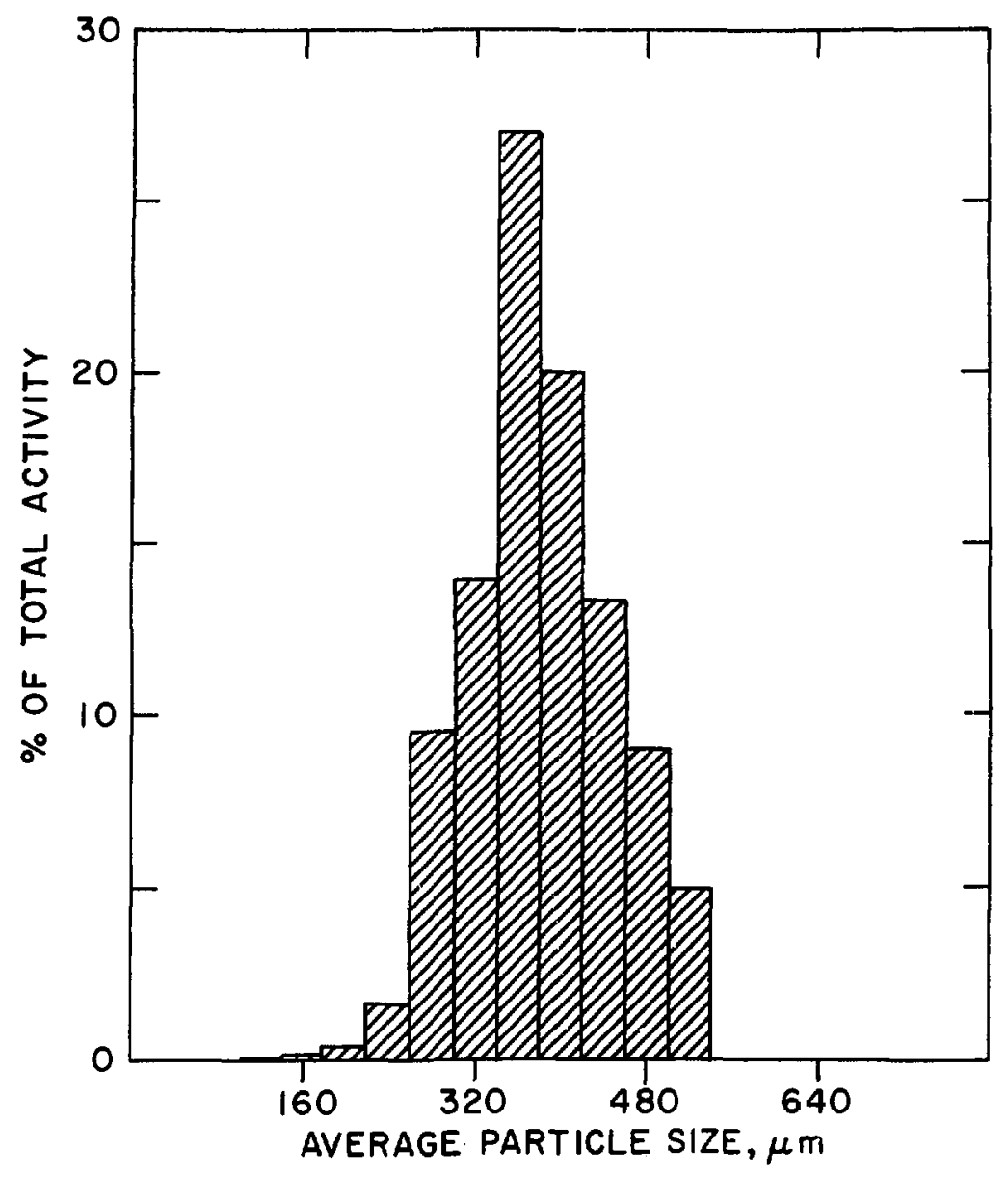

Figure 4. Activity vs granule size for Bikini ash.

function. This simple power function model gave a best fit to the results recorded by Norment.

Tsuzuki reported the observed fallout arrival tive, cessation time, and granule size distribution for Bikini Ash (Ts55). These data were used to model a power function relationship which related granule size to granule fall time specifically for BRAvO fallout as follows:

where

$$
T=79.5 \quad D^{-0.524} \text {, }
$$

$T=$ granule fall tine in hours post-BRAvo,

D = granule size, micrometers.

It was assumed by $u$ s that the largest granules in the Bikini ash fell upon arrival and the smallest fell upon cessation of fallout. We used Bq. (2) to determine granule size distribution at Rongelap, Utirik, and Sifo Islands. To deter- 
mine the rate at which activity built up on the surface at these locations, we used the relationship between activity and granule size previously described.

Equation (2) is a simple model to describe fall time versus granule size. The bulk of the activity of BRAVO was at the base of the cloud at 17 to $29 \mathrm{~km}$ (10 to $20 \mathrm{miles)} \mathrm{aboveground,} \mathrm{ten} \mathrm{minutes} \mathrm{after} \mathrm{the} \mathrm{burst} \mathrm{(OC68).} \mathrm{Gran-}$ ules of a given size were spread throughout the stem, the base of the cloud, and up to the cloud top at $40 \mathrm{~km}$ ( $25 \mathrm{miles).} \mathrm{In} \mathrm{fact,} \mathrm{the} \mathrm{entire} \mathrm{distribution} \mathrm{of}$ granule sizes would reach the surface at any point in time, not just one size at one time. Our simple model ( $\mathrm{Eq}$. (2)), which we assumed for our purposes of estimating the rate-of-rise of exposure rate, the rate of accumulation of activity at the surface, and the accumulated external exposure during the period of rising exposure rates, was in agreement with measurements on rate-of-rise of exposure rate for weapons tests made during the Hardtack Series in 1957 (USPHS59) and with the rate-of-rise of exposure rate measured for one half-hour at Rongerik Ato11 on March 1, 1954 (So55).

These estimates of granule fall time, granule size, and activity versus granule size were combined in a straightforward manner to determine the cumulative percent of activity deposited on the surface of the 5 th Lucky Dragon versus time after the BRAVO explosion. The cumblative percent is plotted in Figure 5. The fallout was first observed by the fishermen on the Lucky Dragon at 3 hours post-detonation. Examination of Figure 5 indicates that the bulk of activity had fallen on the fishing vessel by 4 hours post-detonation. Granules could no longer be seen falling by the crew of the 5 th Lucky Dragon at 8 hours post-detonation (Ts55).

The Rongelap people who were interviewed at the time of evacuation indicated to Sharp that the granules were noticed first at 5 hours postdetonation (Sh57). These people were about $210 \mathrm{~km}$ (130 miles) from Nama Island, Bikini Ato11, the origin or center of BRAVO fallout. Duration of the fallout was observed to be about 7 hours at Rongelap Island (Sh57). Using Eq. (2), we estimated granule size for Rongelap Island on the basis of observed fallout arrival and cessation times. The Rongelap granule size distribution was assumed to have the same shape as Bikini ash. Assuming that the activity of a granule was proportional to the 3.5 power of the granule size, we estimated the percent of total activity versus granule size at Rongelap (see Figure 6). For fallout at Rongelap Island, the size corresponding to median activity was about $150 \mathrm{\mu m}$ ( $6 \times 10^{-3}$ in.). The cumulative percent of total activity deposited on the surface of Rongelap Island versus time post-detonation (see Figure 7) was estimated by us using the same method described here for Bikini ash.

Fallout was not visible at Utirik Island. The first analysis of arrival time of BRAVO fallout, based on an assumed mean wind speed, was estimated by Sondhaus et $a 1$. to be 22 hours post-detonation ( $\mathrm{Cr} 56)$. Fallout cessation was estimated to be 34 hours post-detonation.

We estimated new values for fallout arrival and cessation times at Utirik Island on the basis of observations made by persons on the 5 th Lucky Dragon, on Rongelap Island, and the military outpost on Rongerik Atoll. Fallout was first seen at $1.50 \mathrm{~km}$ (90 miles) at 3 hours post-detonation by the Japanese 

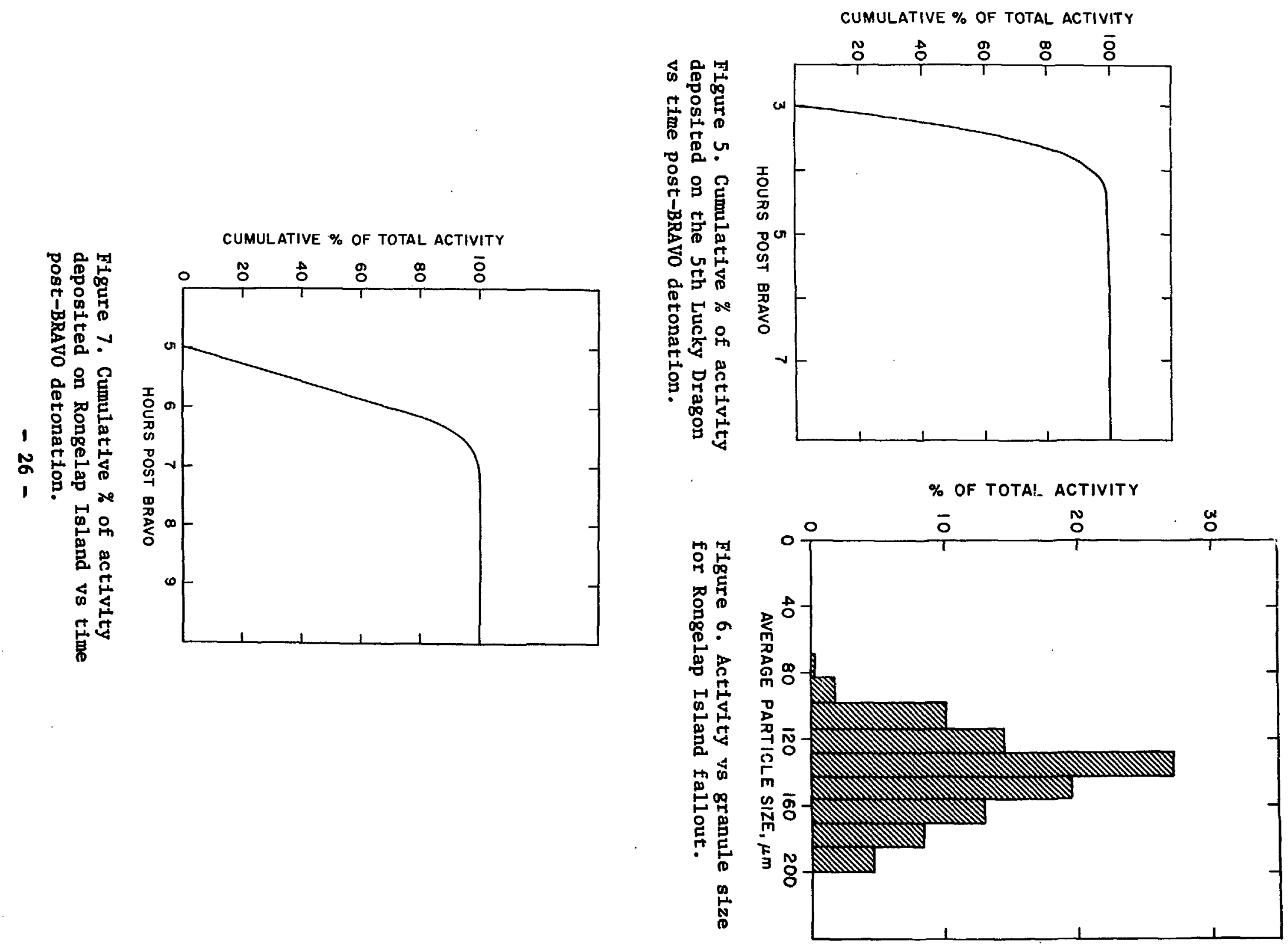
fisherwen and lasted for 5 houra (Ts55). It was then seen at Rongelap Island at $210 \mathrm{~km}$ (130 miles) at 5 hours post-detonation and it lasted for 7 hours ( $8 \mathrm{~h} 57$ ). Fallout reported by military personnel otationed at Eniwetak Island, $270 \mathrm{~km}$ (170 miles) from ground zero, was first observed at about 7 hours post-detonation (Sh57), and it lasted into the night and perhapa into the next day (Sh57). Prom a linear regression fit of the values for distance versus time of arrival or distance veraus time of duration, we extrapolated to arrive at estimates of fallout arrival and cessation times of 17 hours and 36 hours post-detonation, respectively, at Utirik Island. These derived values for fallout arrival and cessation times departed somewhat from the original estimates of Sondhaus.

On the basis of $\mathrm{Bq}$. (2) and the new estimates of fallout arrival and cessation time, we determined a granule size distribution for the Utirik Island location. Based on Lavrenchik's summary (La56) we assuned that activity of a granule was proportional to the 3.5 power of the size, and used $\mathrm{Eq}$. (2) to produce an activity versus granule size distribution (see Figure 8 ). The relative number of granules in each size class was based on the Bikini ash distribution (Su56). The granule size corresponding to the median activity at Utirik Island was about $14.5 \mathrm{~mm}\left(6 \times 10^{-4} \mathrm{in.}\right)$. The granule size distribution estimated by us was in agreement with the fact that fallout was not visible to the eye at Utirik. The cumulative percent of total activity deposited on the surface of Utirik. Island (see Figure 9) was also estimated.

An adjustment for radioactive decay, for the period of time when fallout began to the time it reached the surface, was not accounted for by us when Figures 5, 7, and 9 were drawn. The activity referred to in these figures

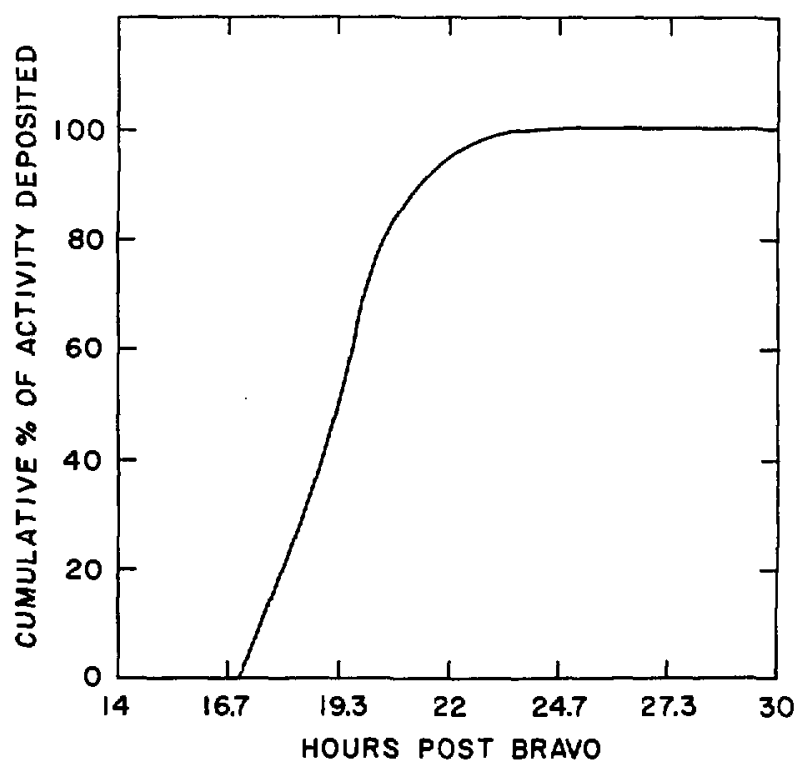

Figure 8. Activity vs granule size for Utirik Island fallout.

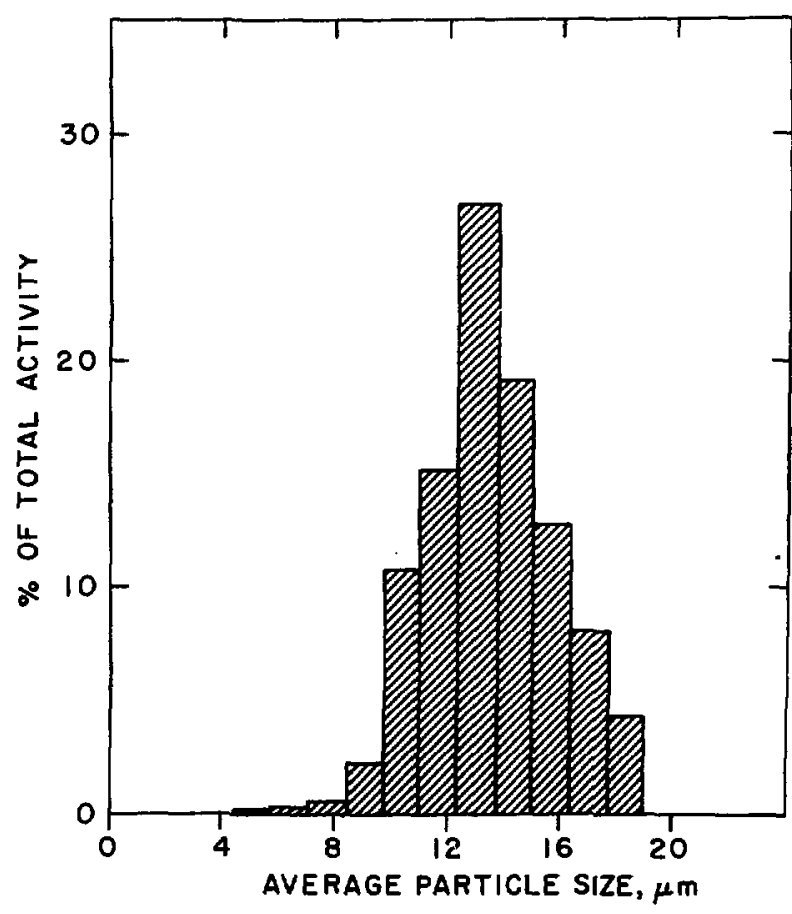

Figure 9. Cumulative $\%$ of activity deposited on Utirik Island vs time post-BRAvo detonation. 
was that wich would have existed at the onset of fallout at each location. Correction for decay leads us to estimate a slightly steeper rise to the curve for cumulative percent activity versus time post-BRAvo detonation.

Eighteen Rongelap people went to Sifo Island, Ailingnae Atoll, to fish and to make copra (Sh57). They left Rongelap Island prior to or at about the time of the BRAVO detonation (Sh57). These people were located about $150 \mathrm{~km}$ (90 miles) from the detonation site at the tine of fallout arrival, and thus, would have received fallout similar in granule size to that shown in Figure 4 for Bikini ash. Their location was further south than the 5 th Lucky Dragon, however, and much 1 ess debris per unit area ultimately fell on Sifo Island. The fallout encountered by these 18 people was estimated to be off the centerline of maximum activity of the BRAVO cloud by about $30 \mathrm{~km}$ (20 miles).

\section{d. A Simple Mode1 for Exposure-Rate History at Rongelap, Sifo, and}

Utirik Islands. We combined the exposure-rate survey by the radsafe team of the USS PHILIP (OC68), the early fallout decay exponents indicated by Miller (0C68), and the time of arrival of fallout at Rongelap to estimate the exposure-rate history prior to evacuation (see Table 11). This exposure-rate history would not include the contribution fron ron-fission-fragment nuclides since it was an extrapolation which we based on the fission product decay exponent given by Miller (0C68). The total integrated exposure at $1 \mathrm{~m}$ above Rongelap Island, from the time of onset of fallout until evacuation, was $4.6 \times 10^{-2} \mathrm{C} \mathrm{kg}^{-1}$ (180 R). (This compares to $7.2 \times 10^{-2} \mathrm{C} \mathrm{kg}^{-1}(280 \mathrm{R})$ based on Bikini ash results; details of this estimate are given in upcoming sections.) We estimated the mean exposure rate to be $3.1 \times 10^{-3} \mathrm{C} \mathrm{kg}^{-1} \mathrm{~h}^{-1}\left(12 \mathrm{R} \mathrm{h}^{-1}\right)$ at 5 hours post-detonation. We assumed for this estimate of peak exposure rate that all the fallout was on the ground at the onset, that is, an instantaneous rise in exposure rate from zero to its maximum value.

The radsafe team of the USS PHILIP surveyed Sifo Island and the radsafe team of the USS RENSHAW surveyed Utirik Island during evacuation efforts (0C68). The exposure-rate histories for both islands were estimated from these survey results and are given in Table 11 . As before, the exposure rates listed in Table 11 were based on Miller's decay estimates and we do not account here for buildup and peaking of radioactivity. Sondhaus reported that surveys at evacuation were performed with only one survey neter (AN/PDR-39), and that this instrument had not been calibrated recently and its operating condition was not known to be satisfactory at the time of use (Cr56). Sondhaus, therefore, based his estimates of external exposure on surveys made with calibrated instruments 7,8 , and 9 days after BRAVO detonation. Estimates of exposure in Table 11 wich we made with evacuation survey results are, however, in agreenent with estimates of cumulated exposure made by Sondhaus. Thus, we conclude the survey results by the radsafe teams were accurate.

A more refined estimate of external exposure-rate history and cumulated external whole-body absorbed dose performed by us was based on Bikini ash results as follows. 


\section{Table 11}

BRAvo Falloue Exposure Rate Decline Based on Miller's (OC68) Decay Estimates

\begin{tabular}{|c|c|c|c|c|c|c|}
\hline \multicolumn{4}{|c|}{ Ronge lap Island, Rongelap Atoll } & \multicolumn{3}{|c|}{ Utirik Island, Utirik Atoll } \\
\hline Time & $\begin{array}{l}\text { Post-Detonation, } \\
\text { hours }\end{array}$ & $\begin{array}{l}\text { Exposure } \\
\text { Rate } \\
\text { R h-la }\end{array}$ & $\begin{array}{c}\text { Cumulated } \\
\text { Exposure, } \\
\mathrm{R}^{\mathrm{b}}\end{array}$ & $\begin{array}{c}\text { Time Post-Detonation, } \\
\text { hours }\end{array}$ & $\begin{array}{l}\text { Exposure } \\
\text { Rate. } \\
\text { R h-1a }\end{array}$ & $\begin{array}{l}\text { Cumulated } \\
\text { Expoéure, } \\
\text { Eb }\end{array}$ \\
\hline & $\begin{array}{r}5 \\
7 \\
9 \\
17 \\
20 \\
25 \\
30 \\
35 \\
40 \\
45 \\
54\end{array}$ & $\begin{array}{c}12 \\
9.0 \\
7.3 \\
4.4 \\
3.8 \\
3.2 \\
2.7 \\
2.3 \\
2.0 \\
1.8 \\
1.5 \mathrm{C}\end{array}$ & $\begin{array}{c}- \\
21 \\
37 \\
84 \\
96 \\
110 \\
130 \\
140 \\
150 \\
160 \\
180\end{array}$ & $\begin{array}{l}17 \\
19 \\
21 \\
24 \\
27 \\
30 \\
35 \\
40 \\
45 \\
55 \\
75 \\
78\end{array}$ & $\begin{array}{l}0.46 \\
0.42 \\
0.39 \\
0.35 \\
0.31 \\
0.28 \\
0.24 \\
0.21 \\
0.19 \\
0.15 \\
0.10^{d} \\
0.095\end{array}$ & $\begin{array}{l}0.88 \\
3.7 \\
3.8 \\
3.8 \\
4.7 \\
i .0 \\
\because .1 \\
1.1 \\
1.8 \\
12 \\
12\end{array}$ \\
\hline \multicolumn{7}{|c|}{ Sifo Island, Ailingnae Atoll } \\
\hline Time & $\begin{array}{l}\text { Post-Detonation, } \\
\text { hours }\end{array}$ & $\begin{array}{l}\text { Exposure } \\
\text { Rate } \\
\text { R h }\end{array}$ & $\begin{array}{c}\text { Cumulated } \\
\text { Exposure, } \\
\mathbf{R}^{\mathbf{b}}\end{array}$ & \multirow{2}{*}{\multicolumn{3}{|c|}{$\begin{array}{l}\text { an air at about one meter above surface, multiply } \\
\text { by } 2.58 \times 10^{-4} \text { to obtain } \mathrm{ckg}^{-1} \mathrm{~h}^{-1} \text {. } \\
\text { bNumerical integration, multiply by } 2.58 \times 10^{-4} \\
\text { to obtain } \mathrm{c} \mathrm{kg}^{-1} \text {. } \\
\text { cVillage average: maximum was } 1.9 \mathrm{R} \mathrm{h}^{-1} \\
\text { USS PHILIP report (Oc68). } \\
\text { dVillage average; maximum was } 0.13 \mathrm{R} \mathrm{h}^{-1} \\
\text { USS RENSHAW report (OC68). } \\
\text { eVillage average; maximum was } 0.48 \mathrm{R} \mathrm{h}^{-1} \\
\text { USS PHILIP report (0C68). }\end{array}$}} \\
\hline & $\begin{array}{r}3 \\
5 \\
7 \\
9 \\
15 \\
20 \\
25 \\
30 \\
35 \\
40 \\
45 \\
50 \\
57 \\
62\end{array}$ & $\begin{array}{l}6.4 \\
4.0 \\
3.0 \\
2.4 \\
1.6 \\
1.3 \\
1.1 \\
0.88 \\
0.76 \\
0.66 \\
0.59 \\
0.53 \\
0.45 \\
0.41 \text { e }\end{array}$ & $\begin{array}{l}- \\
10 \\
17 \\
23 \\
35 \\
42 \\
48 \\
53 \\
57 \\
61 \\
64 \\
67 \\
70 \\
72\end{array}$ & & & \\
\hline
\end{tabular}




\section{e. Activity and Exposure Rate History Based on Bikini Ash}

i. Areal Activity and Exposure Rate from Nuclides Observed on Day 26. We used the Yamatera and Tsuzuki results to estimate BRAYO fallout activity on the ground and exposure rate prior to evacuation. We accounted for the fractionation of fission products, the presence of transuranic and activation products observed in Bikini ash, and a buildup followed by a decline of exposure rate. The Japanese results, summarized in Table 9, were used to generate the percent of fallout beta activity represented by each nuclide in Bikini ash (Table 12, colum 2). The values in this column were based on the mean value of the Yamatera and Tsuzuki result if two values of a nuclide's beta activity in Bikini ash were reported. If not, only the one value was used. We nalculated the day-26 exposure rates, at $1 \mathrm{~m}$ above the surface of a planar source of a unit area of Bikini ash activity (Table 12, column 3), for each nuclide. We based the estimate on data of Beck (Be80) or Rocher (Ko80) and results recorded in Table 12, colum 2. Beck recorded factors to convert activity to exposure-rate for a number of particulate gamma-emitting fission products and for a number of particulate activation products and residual nuclear materials on the ground, as a result of weapons tests (Be80). By summing each nuclide's exposure rate relative to total Bikini ash activity per unit area, we estimated an exposure-rate conversion factor for Bikini ash to be $1.12 \times 10^{-17} \mathrm{C} \mathrm{kg}^{-1} \mathrm{a}^{-1} \mathrm{~Bq}^{-1} \mathrm{~m}^{2}(5.8 \times$ $10^{-3} \mu R \mathrm{~h}^{-1} \mathrm{mCi} \mathrm{im}^{-1} \mathrm{~km}^{2}$ ). By inverting this factor and multiplying by the fraction of each nuclide's beta activity in Bikini ash (see Table 12, column 2), we estimated the beta activity of each nuclide per unit area, which was relative to a unit fallout exposure rate from Bikini ash.

Held (He65) reported a mean exposure-rate at Rongelap Is land of about $2.9 \times 10^{-9} \mathrm{C} \mathrm{kg}^{-1} \mathrm{~s}^{-1}(40 \mathrm{mR} \mathrm{h}-1)$ at 26 days post-detonation. He also reported a storm with heavy rain two weeks post-detonation (He65). This was followed by a reduction in exposure rate greater than he would have expected from decay of BRAVO fallout. Glasstone (G162) reported a $40 \%$ reduction after 25 days for the BRAVO exposure rate which i:e attributed to weathering in certain areas of the Marshall Islands.

We estimated the reduction in exposure rate due to weathering at Rongelap Island on the basis of the survey taken by the USS PHILIP radsafe team. We assumed the survey at this early time post-detonation to be a measurement of unweathered fallout and assumed a decay exponent $m=-1.4$ from day 2.2 to day 26. This value for $m$ was the mean value calculated for the decay of the nuclide mixture present at Rongelap 2.2 to 26 days post-detonation, which we based on the gamma decay of 142 nuclides tabulated in Table 13. Specifically, we accounted for the contribution to exposure rate from 1 ) the transuranic nuclides $237_{\mathrm{U}}$ and $\left.{ }^{239} \mathrm{~Np}, 2\right)$ the neutron-induced nuclides, $35 \mathrm{~s}$ and $45 \mathrm{Ca}, 3$ ) the day-26 fission products which had fractionated according to Japanese results (Ya56, T855), and 4) the ission product and transuranic product precursors initially present on day 2.2 . The day -26 value of the exposure rate which we extrapolated from the measurement made by the radsafe team on day 2.2 was $18 \%$ greater than that reported by Held. Thus, we estimated that, had the rainstorm not occurred, the mean unweathered exposure rate on Rongelap on day-26 would have been $3.4 \times 10^{-9} \mathrm{C} \mathrm{kg}^{-1} \mathrm{~s}^{-1}\left(47 \mathrm{mR} \mathrm{h}{ }^{-1}\right)$. 
Table 12

BRAVO Fallout Beta Activity Related to BRAVO Fallout Exposure Rate

Day 26 Post-Detonation

\begin{tabular}{|c|c|c|c|}
\hline Nuclide & $\begin{array}{l}\text { Z of Bikini Ash } \\
\text { Beta Activity }\end{array}$ & 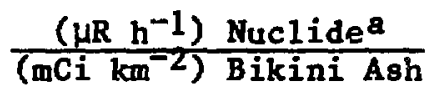 & $\frac{\left(\mathrm{mCi} \mathrm{km}^{-2}\right) \text { Nuclide }}{\left(\mu \mathrm{R} \mathrm{h}^{-1}\right) \text { Bikini Ash }}$ \\
\hline $\begin{array}{l}89_{\mathrm{Sr}} \\
90_{\mathrm{Sr}} \\
90_{\mathrm{Y}}\end{array}$ & $\begin{array}{l}1.3 \\
.013 \\
.013\end{array}$ & $\begin{array}{l}3.3 \times 10^{-8} \\
0.0 \times 10^{0} \\
3.5 \times 10^{-11}\end{array}$ & $\begin{array}{l}2.2 \times 10^{0} \\
2.2 \times 10^{-2}\end{array}$ \\
\hline $\begin{array}{l}90 \mathrm{Y} \\
91_{\mathrm{Y}} \\
95_{\mathrm{Zr}}\end{array}$ & $\begin{array}{l}.013 \\
8.0 \\
6.2\end{array}$ & $\begin{array}{l}3.5 \times 10^{-11} \\
5.0 \times 10^{-6} \\
8.6 \times 10^{-4}\end{array}$ & $\begin{array}{l}2.2 \times 10^{-2} \\
1.4 \times 10^{1} \\
1.1 \times 10^{1}\end{array}$ \\
\hline $\begin{array}{l}95 \mathrm{Nb} \\
103_{\mathrm{Ru}}\end{array}$ & $\begin{array}{l}2.7 \\
5.0\end{array}$ & $\begin{array}{l}3.9 \times 10^{-4} \\
4.5 \times 10^{-4}\end{array}$ & $\begin{array}{l}4.7 \times 10^{0} \\
8.6 \times 10^{0}\end{array}$ \\
\hline $\begin{array}{l}106_{\mathrm{Ru}} \\
106_{\mathrm{Rh}}\end{array}$ & 0.70 & $0.0 \times 10^{0}$ & $1.2 \times 10^{0}$ \\
\hline $\begin{array}{l}100 \mathrm{Rh} \\
129 \mathrm{Te} \\
129 \mathrm{~m}_{\mathrm{Te}}\end{array}$ & $\begin{array}{l}0.70 \\
0.35 \\
0.95\end{array}$ & $\begin{array}{l}2.7 \times 10^{-5} \\
3.6 \times 10^{-6} \\
5.3 \times 10^{-6}\end{array}$ & $\begin{array}{l}1.2 \times 10^{0} \\
6.0 \times 10^{-1} \\
1.6 \times 10^{0}\end{array}$ \\
\hline $\begin{array}{l}132 \mathrm{Te} \\
131_{\mathrm{I}}\end{array}$ & $\begin{array}{l}1.0 \\
4.5\end{array}$ & $\begin{array}{l}3.8 \times 10^{-5} \\
3.3 \times 10^{-4}\end{array}$ & $\begin{array}{l}1.7 \times 10^{0} \\
7.8 \times 10^{0}\end{array}$ \\
\hline $\begin{array}{l}132 \mathrm{I} \\
140_{\mathrm{Ba}}\end{array}$ & $\begin{array}{l}1.0 \\
5.0\end{array}$ & $\begin{array}{l}4.2 \times 10^{-4} \\
1.4 \times 10^{-4}\end{array}$ & $\begin{array}{l}1.7 \times 10^{0} \\
8.6 \times 10^{0}\end{array}$ \\
\hline $\begin{array}{l}140_{\mathrm{La}}^{\mathrm{Da}} \\
141_{\mathrm{Ce}}\end{array}$ & $\begin{array}{l}6.0 \\
8.4\end{array}$ & $\begin{array}{l}1.4 \times 10^{-4} \\
2.3 \times 10^{-3} \\
1.0 \times 10^{-4}\end{array}$ & $\begin{array}{l}8.6 \times 10^{0} \\
1.0 \times 10^{1} \\
1.4 \times 10^{1}\end{array}$ \\
\hline $144 \mathrm{Ce}$ & 1.7 & $4.7 \times 10^{-6}$ & $2.9 \times 10^{0}$ \\
\hline${ }^{144 \mathrm{Pr}}$ & 1.7 & $9.0 \times 10^{-6}$ & $2.9 \times 10^{0}$ \\
\hline $143 \mathrm{Pr}$ & 16 & $2.7 \times 10^{-11}$ & $2.8 \times 10^{1}$ \\
\hline $147 \mathrm{Nd}$ & 9.0 & $2.3 \times 10^{-4}$ & $1.6 \times 10^{1}$ \\
\hline $\begin{array}{l}45 \mathrm{Ca} \\
237 \mathrm{II}\end{array}$ & 0.20 & $1.8 \times 10^{-12}$ & $3.5 \times 10^{-1}$ \\
\hline${ }^{239} \mathrm{Pu}(\alpha)$ & $\begin{array}{r}20 . \\
0.0004\end{array}$ & $\begin{array}{l}4.6 \times 10^{-4} \\
5.4 \times 10^{-10}\end{array}$ & $\begin{array}{l}3.5 \times 10^{1} \\
6.9 \times 10^{-4}\end{array}$ \\
\hline $35_{\mathrm{S}}$ & 0.050 & $0.0 \times 10^{0}$ & $8.6 \times 10^{-2}$ \\
\hline
\end{tabular}

aMultiply by $1.94 \times 10^{-15}$ to obtain $\mathrm{C} \mathrm{kg}^{-1} \mathrm{~s}^{-1} \mathrm{~Bq}^{-1} \mathrm{~m}^{2}$. bivide by $1.94 \times 10^{-15}$ to obtain $\mathrm{Bg} \mathrm{m}^{-2} \mathrm{c}^{-1} \mathrm{~kg} \mathrm{~s}$.

ii. Areal Activity at Fallout Cessation. Using the above estimate of the mean unweathered exposure rate on day 26 , we estimated the mean unweathered activity per unit area to be $1.0 \times 10^{4} \mathrm{~Bq} \mathrm{~m} \mathrm{~m}^{-2}\left(2.4 \times 10^{2} \mathrm{mCi} \mathrm{km}^{-2}\right)$. We made this estimate by multiplying $47 \mathrm{mR} \mathrm{h}$ by 1000 and then multiplying this product by the activity per unit area per unit Bikini ash exposure rate (see Table 12, column 4). 
Although the magnitudes of the uncertainties in the mean unweather:ed activity per unit area were not well defined, we thought that the eatimates for Rongelap Island had a standard deviation based partly on the original Bikini Ash activity measurements (e.8., $95 \mathrm{Zr} \mathrm{S.D.}= \pm 20 \%$ (Is56)) and partly on the variation in exposure-rate measurements (e.g., radsafe team survey S.D. $= \pm 207$ (0C68)). A measurement of activity per unit area based on a single soil sample would be highly uncertain, because of random fallout deposition and because of physical mechanisms which move deposited fallout. This variation was dampened considerably by our use of exposure-rate survey results to estimate mean surface activity rather than use of a few gross beta measurements on soil. Our estimate of the standard deviation for the few soil samples collected by the radsafe team was $\pm 140 \%$ of the mean value, based on the surface activity measurements reported by $0^{\prime}$ Conner (OC68) for surface samples taken shortly after detonation from one island in the Northern Marshall Islands. If soil sample results were used in the final estimate of dose, this large standard deviation would propagate through the calculations. Thus, we chose a method which offered greater certainty in the result.

Our estimate of each nuclide's mean unweathered activity per unit area of Rongelap Island was extrapolated back to 0.5 day post-detonation. Results are listed in Table 13. The 0.5-day post-detonstion time was chosen as the time at which the fallout at Rongelap Island had effectively ceased (Sh57). We used first-order linear kinetics for serially related nuclide species (Bal0) and decay schemes from the Table of the Isotopes (Le78) in order to calculate the 0.5 -day activity from the day-26 activity.

iii. Areal Activity of Nuclides Without Descendants in Bikini Ash. Many short-lived nuclides did not have daughter radionuclides present on day 26. We based the activity of these short-lived nuclides on the activity of a reference nuclide. Equation (3) was used by us to relate the unknown activity of the short-lived nuclide with no daughters present on day 26 to the known activity of a nuclide which had fractionated in the same fashion as the unknown. Thus, if no isobar was present on day 26 , an isotope or an isotope of an isobar of the unknown was chosen to represent the fractionation behavior and be the reference nuclide for the estimate of activity per unit area. The equation used to relate activity of a short-lived nuclide to a reference nuclide was

where

$$
A=\frac{B \lambda_{a} A_{n}}{\lambda_{b} B_{n}},
$$

$$
\begin{aligned}
& A=\text { activity of nuclide } A \text { per unit area at time } t \text { post-detonation, } \\
& B=\text { activity of nuclide } B \text { per unit area at time } t \text { post-detonation, } \\
& \lambda_{a}=\text { decay constant of nuclide } A \text {, } \\
& \lambda_{b}=\text { decay constant of nuclide } B, \\
& A_{n}=\text { number of } A \text { atoms per unit fission at time } t, \\
& B_{n}=\text { number of } B \text { atoms per unit fission at } t i m e t .
\end{aligned}
$$

The quantity $A_{n}$ or $B_{n}$ was calculated using 1) first-order linear kinetics equations, 2) fission yields for $14-\mathrm{MeV}$ fission of ${ }^{2} 38 \mathrm{U}$ obtained from the evaluated nuclear data files of the National Nuclear Data Center 
Table 13

Estimated Unweathered Activity on Surface and Exposure Rate at One Meter, Rongelap Island

\begin{tabular}{|c|c|c|c|c|c|}
\hline Nuclide & $\begin{array}{l}\text { Reference } \\
\text { Nuclide }\end{array}$ & $\begin{array}{c}\text { H+0.5 Day } \\
\text { Activity } \\
\text { per Unit Area, } \\
\text { Ci km-2a }\end{array}$ & $\begin{array}{l}\mathrm{H}+0.5 \text { Day } \\
\text { Exposure } \\
\text { Rate, } \mathrm{R} \mathrm{h}-1 \mathrm{~b}\end{array}$ & $\begin{array}{c}\text { H+26 Day } \\
\text { Activity } \\
\text { per Unit Area, } \\
\text { Ci km-2a }\end{array}$ & $\begin{array}{l}\text { H+26 Day } \\
\text { Exposure } \\
\text { Rate, } R \mathrm{~h}^{-1 b}\end{array}$ \\
\hline 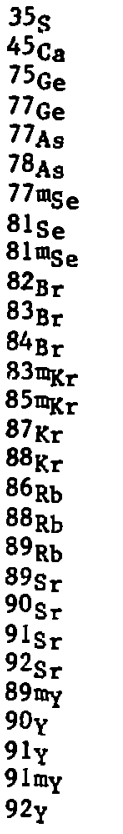 & $\begin{array}{l}35 \mathrm{~S} \\
45 \mathrm{Ca} \\
95 \mathrm{Zr} \\
95 \mathrm{Zr} \\
95 \mathrm{Zr} \\
95 \mathrm{Zr} \\
95 \mathrm{Zr} \\
95 \mathrm{Zr} \\
95 \mathrm{Zr} \\
95 \mathrm{Zr} \\
95 \mathrm{Zr} \\
95 \mathrm{Zr} \\
95 \mathrm{Zr} \\
95 \mathrm{Zr} \\
95 \mathrm{Zr} \\
95 \mathrm{Zr} \\
95 \mathrm{Zr} \\
91 \mathrm{Y} \\
89 \mathrm{Sr} \\
89 \mathrm{Sr} \\
90 \mathrm{Sr} \\
91 \mathrm{Y} \\
91 \mathrm{Y} \\
89 \mathrm{Sr} \\
90 \mathrm{Y} \\
91 \mathrm{Y} \\
91 \mathrm{Y} \\
91 \mathrm{Y}\end{array}$ & $\begin{array}{l}5.0 \times 10^{0} \\
1.8 \times 10^{0} \\
4.9 \times 10^{0} \\
9.0 \times 10^{0} \\
1.5 \times 10^{1} \\
5.7 \times 10^{1} \\
4.7 \times 10^{-2} \\
1.9 \times 10^{-1} \\
1.3 \times 10^{-1} \\
2.8 \times 10^{-2} \\
1.8 \times 10^{3} \\
4.6 \times 10^{-2} \\
5.0 \times 10^{4} \\
7.9 \times 10^{3} \\
4.1 \times 10^{2} \\
8.9 \times 10^{3} \\
5.7 \times 10^{-3} \\
1.7 \times 10^{4} \\
3.9 \times 10^{-9} \\
1.5 \times 10^{2} \\
1.0 \times 10^{0} \\
5.7 \times 10^{4} \\
2.0 \times 10^{4} \\
1.4 \times 10^{-3} \\
1.4 \times 10^{-1} \\
6.6 \times 10^{2} \\
3.4 \times 10^{4} \\
8.4 \times 10^{4}\end{array}$ & $\begin{array}{l}2 \\
2.5 \times 10^{-12} \\
2.3 \times 10^{-6} \\
1.9 \times 10^{-4} \\
1.9 \times 10^{-6} \\
1.2 \times 10^{-3} \\
6.7 \times 10^{-8} \\
2.6 \times 10^{-6} \\
2.6 \times 10^{-8} \\
1.3 \times 10^{-6} \\
2.5 \times 10^{-4} \\
1.3 \times 10^{-6} \\
3.0 \times 10^{-2} \\
2.7 \times 10^{-2} \\
5.3 \times 10^{-3} \\
2.7 \times 10^{-1} \\
9.2 \times 10^{-9} \\
1.8 \times 10^{-1} \\
1.4 \times 10^{-13} \\
3.8 \times 10^{-7} \\
- \\
7.1 \times 10^{-1} \\
4.6 \times 10^{-1} \\
2.4 \times 10^{-8} \\
3.7 \times 10^{-11} \\
3.7 \times 10^{-5} \\
3.4 \times 10^{-1} \\
3.8 \times 10^{-1}\end{array}$ & $\begin{array}{c}4.0 \times 10^{0} \\
1.7 \times 10^{1} \\
- \\
- \\
- \\
- \\
- \\
- \\
- \\
- \\
- \\
- \\
- \\
- \\
- \\
- \\
- \\
1.0 \times 10^{2} \\
1.0 \times 10^{0} \\
- \\
- \\
- \\
1.0 \times 10^{0} \\
6.6 \times 10^{2} \\
- \\
-\end{array}$ & $\begin{array}{c}- \\
2.3 \times 10^{-12} \\
- \\
- \\
- \\
- \\
- \\
- \\
- \\
- \\
- \\
- \\
- \\
- \\
- \\
- \\
- \\
- \\
2.4 \times 10^{-7} \\
- \\
- \\
- \\
2.5 \times 10^{-10} \\
3.7 \times 10^{-5} \\
- \\
-\end{array}$ \\
\hline $\begin{array}{l}93 \mathrm{Y} \\
95 \mathrm{Zr} \\
97 \mathrm{Zr} \\
95 \mathrm{Nb} \\
95 \mathrm{mb} \\
97 \mathrm{Nb} \\
97 \mathrm{~m} \\
99 \mathrm{Mb} \\
99 \mathrm{Mr} \\
103_{\mathrm{Ru}}\end{array}$ & $\begin{array}{l}91 \mathrm{Y} \\
95 \mathrm{Zr} \\
95 \mathrm{Zr} \\
95 \mathrm{Yb} \\
95 \mathrm{Zr} \\
95 \mathrm{Zr} \\
95 \mathrm{Zr} \\
95 \mathrm{Zr} \\
95 \mathrm{Zr} \\
103 \mathrm{Ru}\end{array}$ & $\begin{array}{l}7.0 \times 10^{4} \\
6.8 \times 10^{2} \\
4.0 \times 10^{4} \\
3.1 \times 10^{-1} \\
6.4 \times 10^{1} \\
4.4 \times 10^{4} \\
3.9 \times 10^{4} \\
1.5 \times 10^{4} \\
1.0 \times 10^{4} \\
6.4 \times 10^{2}\end{array}$ & $\begin{array}{l}1.1 \times 10^{-1} \\
9.6 \times 10^{-3} \\
1.3 \times 10^{-1} \\
4.0 \times 10^{-6} \\
1.4 \times 10^{-4} \\
5.4 \times 10^{-1} \\
5.3 \times 10^{-1} \\
4.5 \times 10^{-2} \\
2.2 \times 10^{-2} \\
5.9 \times 10^{-3}\end{array}$ & $\begin{array}{c}5.2 \times 10^{2} \\
- \\
2.1 \times 10^{2} \\
= \\
= \\
- \\
- \\
4.0 \times 10^{2}\end{array}$ & $\begin{array}{c}7.2 \times 10^{-3} \\
= \\
2.7 \times 10^{-3} \\
= \\
= \\
= \\
3.8 \times 10^{-3}\end{array}$ \\
\hline
\end{tabular}


Table 13 (cont'd)

\begin{tabular}{|c|c|c|c|c|c|}
\hline Nuclide & $\begin{array}{l}\text { Reference } \\
\text { Nuclide }\end{array}$ & $\begin{array}{c}\text { H+0.5 Day } \\
\text { Activity } \\
\text { per Unit Area, } \\
\text { Ci km-2a }\end{array}$ & $\begin{array}{l}\mathrm{H}+0.5 \text { Day } \\
\text { Exposure } \\
\text { Rate, } \mathrm{R} \mathrm{h}^{-1 \mathrm{~b}}\end{array}$ & $\begin{array}{c}\text { H+26 Day } \\
\text { Activity } \\
\text { per Unit Area, } \\
\text { Ci km-2a }\end{array}$ & $\begin{array}{l}\text { H+26 Day } \\
\text { Exposure } \\
\text { Rate, R h-1b }\end{array}$ \\
\hline $\begin{array}{l}105_{\mathrm{Ru}} \\
106_{\mathrm{Ru}} \\
103 \mathrm{~m}_{\mathrm{Rh}} \\
105_{\mathrm{Rh}} \\
105_{\mathrm{Rh}} \\
106_{\mathrm{Rh}} \\
109_{\mathrm{Pd}} \\
111_{\mathrm{Pd}} \\
111 \mathrm{mPd}_{\mathrm{Pd}} \\
112 \mathrm{Pd} \\
109 \mathrm{~m}_{\mathrm{Ag}} \\
111_{\mathrm{Ag}} \\
11 \mathrm{~m}_{\mathrm{Ag}} \\
112 \mathrm{Ag} \\
113_{\mathrm{Ag}} \\
115_{\mathrm{Ag}} \\
115_{\mathrm{Cd}} \\
115 \mathrm{~m} \mathrm{Cd} \\
117 \mathrm{Cd} \\
117 \mathrm{~m} \\
118_{\mathrm{Cd}}\end{array}$ & 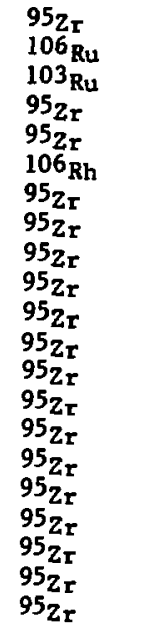 & $\begin{array}{l}2.8 \times 10^{4} \\
5.9 \times 10^{1} \\
6.3 \times 10^{2} \\
1.7 \times 10^{4} \\
7.9 \times 10^{3} \\
5.9 \times 10^{1} \\
1.3 \times 10^{4} \\
2.7 \times 10^{3} \\
3.5 \times 10^{3} \\
2.0 \times 10^{4} \\
1.3 \times 10^{4} \\
3.7 \times 10^{2} \\
2.8 \times 10^{3} \\
2.1 \times 10^{3} \\
1.1 \times 10^{3} \\
2.0 \times 10^{-6} \\
8.3 \times 10^{2} \\
2.4 \times 10^{1} \\
3.3 \times 10^{2} \\
6.3 \times 10^{2} \\
3.0 \times 10^{0}\end{array}$ & $\begin{array}{c}4.1 \times 10^{-1} \\
- \\
1.2 \times 10^{-4} \\
2.5 \times 10^{-2} \\
3.5 \times 10^{-3} \\
2.2 \times 10^{-4} \\
1.7 \times 10^{-4} \\
1.2 \times 10^{-3} \\
2.2 \times 10^{-2} \\
3.1 \times 10^{-4} \\
9.3 \times 10^{-3} \\
1.7 \times 10^{-4} \\
1.9 \times 10^{-5} \\
2.5 \times 10^{-2} \\
5.6 \times 10^{-3} \\
2.0 \times 10^{-1} 1 \\
3.7 \times 10^{-3} \\
9.3 \times 10^{-6} \\
6.1 \times 10^{-3} \\
2.1 \times 10^{-2} \\
-\end{array}$ & $\begin{array}{c}- \\
5.7 \times 10^{1} \\
- \\
- \\
- \\
5.7 \times 10^{1} \\
- \\
- \\
- \\
- \\
- \\
- \\
- \\
- \\
- \\
- \\
- \\
- \\
- \\
-\end{array}$ & $\begin{array}{c}- \\
- \\
- \\
- \\
2.1 \times 10^{-4} \\
- \\
- \\
- \\
- \\
- \\
- \\
- \\
- \\
- \\
- \\
- \\
-\end{array}$ \\
\hline 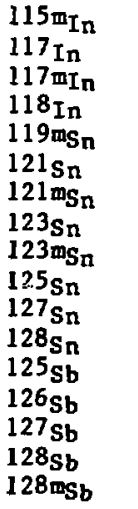 & $\begin{array}{l}95 \mathrm{Zr} \\
95 \mathrm{Zr} \\
95 \mathrm{Zr} \\
95 \mathrm{Zr} \\
95 \mathrm{Zr} \\
95 \mathrm{Zr} \\
95 \mathrm{Zr} \\
95 \mathrm{Zr} \\
95 \mathrm{Zr} \\
95 \mathrm{Zr} \\
132 \mathrm{I} \\
132 \mathrm{I} \\
95 \mathrm{Zr} \\
95 \mathrm{Zr} \\
132 \mathrm{I} \\
132 \mathrm{I} \\
132 \mathrm{I}\end{array}$ & $\begin{array}{l}4.6 \times 10^{2} \\
1.4 \times 10^{3} \\
2.1 \times 10^{3} \\
3.0 \times 10^{0} \\
7.9 \times 10^{-2} \\
4.4 \times 10^{3} \\
2.2 \times 10^{-2} \\
4.3 \times 10^{-1} \\
3.1 \times 10^{-1} \\
5.6 \times 10^{-1} \\
3.8 \times 10^{2} \\
1.5 \times 10^{2} \\
3.5 \times 10^{0} \\
5.3 \times 10^{2} \\
5.1 \times 10^{3} \\
1.9 \times 10^{3} \\
1.9 \times 10^{2}\end{array}$ & $\begin{array}{c}2.7 \times 10^{-3} \\
1.8 \times 10^{-2} \\
3.0 \times 10^{-3} \\
1.3 \times 10^{-5} \\
6.4 \times 10^{-9} \\
- \\
1.4 \times 10^{-9} \\
5.2 \times 10^{-8} \\
7.3 \times 10^{-7} \\
3.1 \times 10^{-6} \\
1.3 \times 10^{-2} \\
1.9 \times 10^{-3} \\
2.8 \times 10^{-5} \\
2.5 \times 10^{-2} \\
6.6 \times 10^{-2} \\
1.1 \times 10^{-1} \\
6.8 \times 10^{-3}\end{array}$ & $\begin{array}{l}- \\
- \\
- \\
- \\
- \\
- \\
- \\
- \\
- \\
- \\
- \\
- \\
- \\
- \\
- \\
-\end{array}$ & $\begin{array}{l}- \\
- \\
- \\
- \\
- \\
- \\
- \\
- \\
- \\
- \\
- \\
- \\
- \\
- \\
- \\
-\end{array}$ \\
\hline
\end{tabular}


Table 13 (Cont'd)

\begin{tabular}{|c|c|c|c|c|c|}
\hline Nuc!ide & $\begin{array}{l}\text { Reference } \\
\text { Nuclide }\end{array}$ & $\begin{array}{c}\mathrm{H}+0.5 \text { Day } \\
\text { Activity } \\
\text { per Unit Area, } \\
\text { Ci km-2a }\end{array}$ & $\begin{array}{l}\mathrm{H}+0.5 \text { Day } \\
\text { Exposure } \\
\text { Rate, R h-1b }\end{array}$ & $\begin{array}{c}\text { H+26 Day } \\
\text { Activity } \\
\text { per Unit Area, } \\
\text { Ci km-2a }\end{array}$ & $\begin{array}{l}\mathrm{H}+26 \text { Day } \\
\text { Exposure } \\
\text { Rate, } \mathrm{R} \mathrm{h}^{-1 \mathrm{~b}}\end{array}$ \\
\hline $\begin{array}{l}129 \mathrm{Sb} \\
130 \mathrm{Sb} \\
131 \mathrm{Sb} \\
125 \mathrm{me}_{\mathrm{Te}} \\
127 \mathrm{Te} \\
127 \mathrm{me}_{\mathrm{Te}} \\
129 \mathrm{Te} \\
129 \mathrm{me} \\
131 \mathrm{Te} \\
131 \mathrm{me}_{\mathrm{Te}} \\
132 \mathrm{Te} \\
133 \mathrm{Te} \\
133 \mathrm{me}_{\mathrm{Te}} \\
134 \mathrm{Te}\end{array}$ & $\begin{array}{l}132 \mathrm{I} \\
132 \mathrm{I} \\
132 \mathrm{I} \\
95 \mathrm{ZI} \\
132 \mathrm{I} \\
132 \mathrm{I} \\
129 \mathrm{Te} \\
129 \mathrm{me}_{\mathrm{Te}} \\
132 \mathrm{I} \\
132 \mathrm{I} \\
132 \mathrm{Te} \\
132 \mathrm{I} \\
132 \mathrm{I} \\
132 \mathrm{I}\end{array}$ & $\begin{array}{l}3.2 \times 10^{4} \\
3.1 \times 10^{0} \\
5.2 \times 10^{-4} \\
1.4 \times 10^{-3} \\
2.4 \times 10^{3} \\
3.7 \times 10^{0} \\
1.4 \times 10^{4} \\
1.1 \times 10^{2} \\
6.8 \times 10^{2} \\
3.1 \times 10^{3} \\
1.8 \times 10^{4} \\
2.7 \times 10^{1} \\
1.3 \times 10^{2} \\
1.4 \times 10^{1}\end{array}$ & $\begin{array}{l}7.9 \times 10^{-1} \\
1.7 \times 10^{-4} \\
1.8 \times 10^{-8} \\
2.0 \times 10^{-9} \\
2.4 \times 10^{-4} \\
1.7 \times 10^{-6} \\
1.5 \times 10^{-2} \\
6.1 \times 10^{-5} \\
5.2 \times 10^{-3} \\
7.9 \times 10^{-2} \\
6.8 \times 10^{-2} \\
4.6 \times 10^{-4} \\
5.4 \times 10^{-3} \\
2.2 \times 10^{-4}\end{array}$ & $\begin{array}{c}- \\
- \\
- \\
- \\
- \\
- \\
2.8 \times 10^{1} \\
7.6 \times 10^{1} \\
- \\
- \\
7.9 \times 10^{1} \\
- \\
- \\
-\end{array}$ & $\begin{array}{c}- \\
- \\
- \\
- \\
- \\
- \\
3.5 \times 10^{-5} \\
6.7 \times 10^{-5} \\
- \\
- \\
3.1 \times 10^{-4} \\
- \\
- \\
-\end{array}$ \\
\hline $\begin{array}{l}129 \mathrm{I} \\
130 \mathrm{I} \\
131 \mathrm{I} \\
132 \mathrm{I} \\
133 \mathrm{I} \\
133 \mathrm{mI} \\
134 \mathrm{I} \\
135 \mathrm{I} \\
131 \mathrm{mXe} \\
133 \mathrm{Xe} \\
133 \mathrm{me}_{\mathrm{Xe}} \\
135 \mathrm{Xe} \\
135 \mathrm{mXe} \\
135 \mathrm{Cs} \\
136 \mathrm{Cs} \\
137 \mathrm{Cs} \\
138 \mathrm{Cs} \\
137 \mathrm{mBa} \\
139 \mathrm{Ba} \\
140_{\mathrm{Ba}} \\
140_{\mathrm{La}} \\
141_{\mathrm{La}}\end{array}$ & $\begin{array}{l}132 I \\
132 I \\
131 I \\
132 I \\
132 I \\
132 I \\
132 I \\
132 I \\
132 I \\
132 I \\
132 I \\
132 I \\
132 I \\
132 I \\
132 I \\
132 I \\
132 I \\
132 I \\
132 I \\
140 \mathrm{Ba} \\
140 \mathrm{La} \\
141 \mathrm{Ce}\end{array}$ & $\begin{array}{l}4.5 \times 10^{-6} \\
2.6 \times 10^{0} \\
3.1 \times 10^{3} \\
1.9 \times 10^{4} \\
6.5 \times 10^{4} \\
1.1 \times 10^{1} \\
6.5 \times 10^{2} \\
7.8 \times 10^{4} \\
1.8 \times 10^{0} \\
2.1 \times 10^{3} \\
3.2 \times 10^{2} \\
8.9 \times 10^{4} \\
1.2 \times 10^{4} \\
1.4 \times 10^{-3} \\
1.5 \times 10^{1} \\
7.0 \times 10^{0} \\
8.7 \times 10^{-1} \\
6.5 \times 10^{0} \\
3.3 \times 10^{3} \\
1.7 \times 10^{3} \\
3.1 \times 10^{2} \\
3.0 \times 10^{4}\end{array}$ & $\begin{array}{l}5.6 \times 10^{-12} \\
1.1 \times 10^{-4} \\
2.2 \times 10^{-2} \\
7.9 \times 10^{-1} \\
7.4 \times 10^{-1} \\
3.1 \times 10^{-4} \\
3.1 \times 10^{-2} \\
2.1 \times 10^{0} \\
1.7 \times 10^{-6} \\
3.2 \times 10^{-3} \\
4.5 \times 10^{-4} \\
4.6 \times 10^{-1} \\
1.0 \times 10^{-1} \\
- \\
6.0 \times 10^{-4} \\
- \\
3.4 \times 10^{-5} \\
7.4 \times 10^{-5} \\
2.1 \times 10^{-3} \\
4.5 \times 10^{-3} \\
1.2 \times 10^{-2} \\
2.1 \times 10^{-2}\end{array}$ & $\begin{array}{c}- \\
- \\
3.5 \times 10^{2} \\
8.0 \times 10^{1} \\
- \\
- \\
- \\
- \\
- \\
- \\
- \\
- \\
- \\
- \\
- \\
- \\
- \\
4.0 \times 10^{2} \\
4.7 \times 10^{2} \\
-\end{array}$ & $\begin{array}{c}- \\
- \\
2.6 \times 10^{-3} \\
3.4 \times 10^{-3} \\
- \\
- \\
- \\
- \\
- \\
- \\
- \\
- \\
- \\
- \\
- \\
- \\
- \\
1.1 \times 10^{-3} \\
1.9 \times 10^{-2} \\
-\end{array}$ \\
\hline
\end{tabular}


Table 13 (cont'd)

\begin{tabular}{|c|c|c|c|c|c|}
\hline Nuclide & $\begin{array}{l}\text { Reference } \\
\text { Nuclide }\end{array}$ & $\begin{array}{c}\text { H+0.5 Day } \\
\text { Activity } \\
\text { per Jnit Area, } \\
\text { Ci km-2a }\end{array}$ & $\begin{array}{l}\text { H+0.5 Day } \\
\text { Exposure } \\
\text { Rate, } R \mathrm{~h}^{-1 b}\end{array}$ & $\begin{array}{c}\text { H+26 Day } \\
\text { Activity } \\
\text { per Unit Area, } \\
\text { Ci ka-2a }\end{array}$ & $\begin{array}{l}\text { H+26 Day } \\
\text { Exposure } \\
\text { Rate, } R \mathrm{~h}^{-1 \mathrm{~b}}\end{array}$ \\
\hline $\begin{array}{l}142 \mathrm{La} \\
141 \mathrm{Ce} \\
143 \mathrm{Ce} \\
144 \mathrm{Ce} \\
143 \mathrm{Pr} \\
144 \mathrm{Pr} \\
144 \mathrm{mPr} \\
145 \mathrm{Pr}\end{array}$ & $\begin{array}{l}141 \mathrm{Ce} \\
141 \mathrm{Ce} \\
141 \mathrm{Ce} \\
144 \mathrm{Ce} \\
143 \mathrm{Pr} \\
144 \mathrm{Pr} \\
141 \mathrm{Ce} \\
141 \mathrm{Ce}\end{array}$ & $\begin{array}{l}2.6 \times 10^{3} \\
9.9 \times 10^{2} \\
1.9 \times 10^{4} \\
1.4 \times 10^{2} \\
9.2 \times 10^{2} \\
1.4 \times 10^{2} \\
1.7 \times 10^{0} \\
2.6 \times 10^{4}\end{array}$ & $\begin{array}{l}1.1 \times 10^{-1} \\
1.2 \times 10^{-3} \\
9.2 \times 10^{-2} \\
4.0 \times 10^{-5} \\
1.5 \times 10^{-10} \\
7.4 \times 10^{-5} \\
7.8 \times 10^{-7} \\
6.1 \times 10^{-3}\end{array}$ & $\begin{array}{c}- \\
6.6 \times 10^{2} \\
- \\
1.4 \times 10^{2} \\
1.3 \times 10^{3} \\
1.4 \times 10^{2} \\
- \\
-\end{array}$ & $\begin{array}{c}7.9 \times 10^{-4} \\
- \\
4.0 \times 10^{-5} \\
2.2 \times 10^{-10} \\
7.4 \times 10^{-5} \\
= \\
-\end{array}$ \\
\hline $\begin{array}{l}146 \mathrm{Pr} \\
144 \mathrm{Nd} \\
147_{\mathrm{Nd}} \\
149_{\mathrm{Nd}} \\
147_{\mathrm{Pm}} \\
149 \mathrm{Pm} \\
150_{\mathrm{Pm}} \\
151_{\mathrm{Pm}} \\
151 \mathrm{Sm} \\
153 \mathrm{Sm} \\
156 \mathrm{Sm} \\
155_{\mathrm{Eu}} \\
156_{\mathrm{Eu}} \\
157_{\mathrm{Eu}} \\
158_{\mathrm{Eu}} \\
159 \mathrm{Gd} \\
161_{\mathrm{Tb}} \\
237_{\mathrm{J}} \\
239_{\mathrm{J}} \\
237_{\mathrm{Np}} \\
239_{\mathrm{Np}} \\
239_{\mathrm{Pu}}\end{array}$ & $\begin{array}{l}141 \mathrm{Ce} \\
141 \mathrm{Ce} \\
147 \mathrm{Nd} \\
141 \mathrm{Ce} \\
141 \mathrm{Ce} \\
141 \mathrm{Ce} \\
141 \mathrm{Ce} \\
141 \mathrm{Ce} \\
141 \mathrm{Ce} \\
141 \mathrm{Ce} \\
141 \mathrm{Ce} \\
141 \mathrm{Ce} \\
141 \mathrm{Ce} \\
141 \mathrm{Ce} \\
141 \mathrm{Ce} \\
141 \mathrm{Ce} \\
141 \mathrm{Ce} \\
237 \mathrm{U} \\
239 \mathrm{U} \\
237 \mathrm{U} \\
239 \mathrm{Pu} \\
239 \mathrm{Pu}\end{array}$ & $\begin{array}{l}2.6 \times 10^{-3} \\
4.7 \times 10^{-17} \\
3.5 \times 10^{3} \\
1.4 \times 10^{3} \\
5.7 \times 10^{-1} \\
4.7 \times 10^{3} \\
3.8 \times 10^{3} \\
4.3 \times 10^{3} \\
5.1 \times 10^{-2} \\
1.3 \times 10^{3} \\
9.6 \times 10^{2} \\
7.3 \times 10^{-1} \\
3.5 \times 10^{1} \\
6.5 \times 10^{2} \\
2.1 \times 10^{-2} \\
1.9 \times 10^{3} \\
9.8 \times 10^{0} \\
2.4 \times 10^{4} \\
1.0 \times 10^{-2} \\
1.1 \times 10^{-5} \\
1.0 \times 10^{5} \\
4.3 \times 10^{-3}\end{array}$ & $\begin{array}{l}5.2 \times 10^{-8} \\
- \\
8.9 \times 10^{-3} \\
9.8 \times 10^{-3} \\
4.1 \times 10^{-11} \\
1.0 \times 10^{-3} \\
1.1 \times 10^{-1} \\
2.5 \times 10^{-2} \\
9.4 \times 10^{-11} \\
1.2 \times 10^{-3} \\
1.9 \times 10^{-3} \\
6.8 \times 10^{-7} \\
8.0 \times 10^{-4} \\
3.0 \times 10^{-3} \\
5.2 \times 10^{-7} \\
1.4 \times 10^{-3} \\
1.3 \times 10^{-6} \\
5.4 \times 10^{-2} \\
8.1 \times 10^{-9} \\
4.0 \times 10^{-12} \\
3.0 \times 10^{-1} \\
5.7 \times 10^{-10}\end{array}$ & $\begin{array}{c}- \\
7.1 \times 10^{2} \\
- \\
- \\
- \\
- \\
- \\
- \\
- \\
- \\
- \\
- \\
- \\
- \\
1.7 \times 10^{3} \\
- \\
- \\
-2 \times 10^{-2}\end{array}$ & $\begin{array}{c}- \\
- \\
1.8 \times 10^{-3} \\
- \\
- \\
- \\
- \\
- \\
- \\
- \\
- \\
- \\
- \\
- \\
3.8 \times 10^{-3} \\
- \\
- \\
4.3 \times 10^{-9}\end{array}$ \\
\hline
\end{tabular}

aultiply by $3.7 \times 10^{4}$ to obtain $\mathrm{Bq} \mathrm{m}^{-2}$.

bultiply by $7.17^{\times 10^{-8}}$ to obtain $\mathrm{C} \mathrm{kg}^{-1} \mathrm{~s}^{-1}$. 
(MNDB2), and 3) branching fractions and decay schemes fron the seventh edition of the Table of Isotopes (Le78). Since each nuclide which we accounted for was the $n^{\text {th }}$ nember of an isobaric chain, the number of atoms at time $t$ would increase or decrease relative to the number present at time of detonation because of decay and in-growth phenowena of precursor isobars. Decay and in-growth phenowena were accounted for using the following equation which was originally described by Bateman (Bal0) and later recast in a more general form by Skrable (Sk75).

where

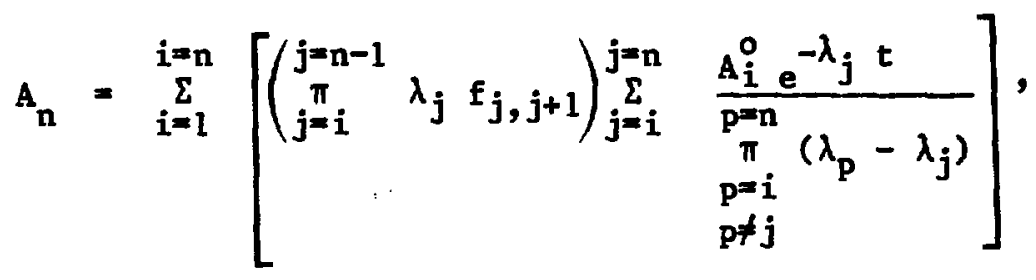

$A_{n}=$ the number of atoms of the $n^{\text {th }}$ member of an isobaric chain at time $t$ post-detonation per unit fission,

$A_{i}^{0}=$ the independent yield at $t=0$ of the $i$ th $i$ sobar in the $A_{n}$ isobaric chain per unit fission,

$\lambda_{j}=$ decay constant of the $j$ th isobar,

$\mathbf{f}_{j, j+1}=$ branching fraction of the $j^{\text {th }}$ isobar leading to the creation of the $j^{\text {th }}+1$ isobar,

$t=$ time post-BRAVO detonation.

The use of Eqs. (3) and (4) allowed us to calculate all fission products present at the time of exposure (see Table 13). We also included in Table 13, the important precursor transuranics and activation products which were based on the Tsuzuki measurements on day 26 (Ts55) and the use of parentdaughter transformation equations given by Bateman (BalO).

iv. Non-Fission-Fragment Nuclides Not Accounted for. The nuclides which may have been present at some level but which remain unaccounted for are

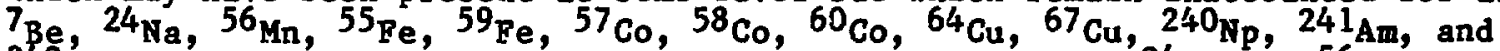
${ }^{242} \mathrm{Cm}$. The decay of two short-lived activation products, ${ }^{24} \mathrm{Na}$ and $56 \mathrm{Mn}$, might have accounted for some of the exposure rate measured at 2.2 days at Rongelap Island. Borg tabulated the photon energy spectrum from a BRAvo fallout sample collected at Rongelap Island (Bo56). The fallout sample was reported to be analyzed at 4 days post-detonation. We determined that the spectrum has a minor peak energy around $850 \mathrm{keV}$. The intensity of the peak was about 5 to $7 \mathrm{k}$ of the total photon intensity. The nuclide $56 \mathrm{Mn}$ has a characteristic photon at $847 \mathrm{keV}$ but so do 30 other nuclides which may have been present (RSIC73). Mather indicated that these short-lived activation products may account for as much as 20 to $50 \%$ of the photon intensity during the first day post-detonation; however, most ${ }^{24} \mathrm{Na}$ and $56_{\mathrm{Mn}}$ activity would be observed close to the point of creation (Ma56). In the case of BRAVO this was near Namu Island, Bikini Atoll. Therefore, we doubt that ${ }^{24} \mathrm{Na}$ and ${ }^{56} \mathrm{Mn}$ contributed much photon exposure at Rongelap I sland.

We approximated the exposure rate contribution from all notaccounted-for nuclides at distances far from the detonation site on the basis of 
fallout atudies at the Nevada Test Site (Hi81). An approxination of the exposure due to all not-accounted-for nuclides listed above would be less than 17 of the tota 1 from day 0.5 to day 2.2 post-detonation. This may not be a good comparative assessment since no study of a device like BRAvo was reported at the Nevada Test site. The fourth shot in the Castle Series, UnIon, was a 9.5-MT device with a number of characteristics similar to those of BRAvo, including its fission-to-fusion ratio. The gross gama decay was measured from 0.2 day post-detonation, unlike BRAVO for which gross game decay was not reported until after 5.5 days had passed. From 0.2 day to 0.3 day the decay exponent was -1.5 . From 0.2 day to 2.2 days it was -1.3 . From 2.2 days to 26 days it was -1.4 . These values of gama-decay exponents were comparable to those we estimated from Bikini ash extrapolations. Significant amounts of not-accounted-for nuclides in the activity produced by UNION might have caused us to estimate a wide difference in decay exponents. Thus, we cónclude that not-accounted-for nuclides contributed very little to the dose received by persons at Rongelap, Utirik, or Sifo Is lands.

v. Input Data to Rinetics Equations. A check on input data for activity per unit fission versus tine was made by us. The theoretical activity of unfractionated iodine isotopes following 10,000 thermonuclear fissions of $238_{\mathrm{U}}$ as given by Crocker (Cr65) was compared to the activity at any time following fission of $238_{\mathrm{U}}$ with $14-\mathrm{MeV}$ neutrons. Our comparison calculation was based on decay schemes from the Table of the Isotopes (Le78), independent yield data for fission products from the National Nuclear Data Center (NNDC82), and Eq. (4). The Crocker yields were based on a slightly different neutron energy spectrum than that used in the calculation made here. The kinetics equations, verified yield data, and our decay scheme approach led to results remarkably similar to those of Crocker. Our estimated maximum difference was approximately $50 \%$ for ${ }^{134}$ I activity at two hours post-detonation. All iodine isotope activities were within $20 \%$ of the Crocker estimate at about 10 hours postdetonation.

vi. Exposure Rate on Day 0.5 and Surface Roughness Effects. We estimated the mean exposure rate from all the nuclides given in Table 13 to be $7.9 \times 10^{-7} \mathrm{C} \mathrm{kg}^{-1} \mathrm{~s}^{-1}\left(1.1 \times 10^{1} \mathrm{R} \mathrm{h}^{-1}\right)$ on day 0.5 post-detonation. We include in this estimate the contribution from noble gas nuclides. Exclusion of the noble gas activity yields $7.0 \times 10^{-7} \mathrm{C} \mathrm{kg}^{-1} \mathrm{~s}^{-1}\left(9.7 \mathrm{R} \mathrm{h}^{-1}\right)$ for the exposure rate at day 0.5 . The exposure-rate history at Rongelap Island based on the particulate activity in Bikini Ash, has been plotted in Figure 10.

Photons emitted by fallout on the surface may have been intercepted by overlying layers of soil or by surface structures. Because of surface roughness effects, the radsafe survey team may have reported an exposure rate which is an underestimate of oni which is produced by a plane source. This would have caused us to underestimate surface activity at Rongelap because Bikini ash activity was normalized to the Rongelap exposure-rate survey made by the radsafe team. The effect of fallout particles penetrating into Rongelap's coral surface was approximated by comparing Beck's values for $\mathrm{mR} \mathrm{h}^{-1} \mu \mathrm{Ci}^{-1} \mathrm{~m}^{2}$ for activity on a smooth flat plane, to a plane where activity was distributed depthwise with a relaxation length of $0.16 \mathrm{~g} \mathrm{~cm}^{-2}$ (Be80). By relaxation length we mean the depth at which the activity in overlying layers of soil is reduced 
by a factor $e$. We estimate that this translates into a 157 underestinate of the activity present if one assumes that the exposure rate was due to a smoth flat plane of activity rather than one distributed depthwise.

Since we normalized activity intake to urine activity excreted, the effect of this underestimate of activity per unit area was inconsequential on thyroid dose estimates. It would, of course, impact on the relative amounts entering the body through the ingestion versus inhalation versus skin absorption pathways but not the total amount taken in. Since in our assessment the ingestion pathway dominated, the impact on thyroid-absorbed duse would be negligible.

vii. Integrated Exposure and Whole-Body Absorbed Dose. The total integrated exposure from the onset of fallout to evacuation was $7.2 \times 10^{-2} \mathrm{C}$ $\mathrm{kg}^{-1}(280 \mathrm{R}) 1 \mathrm{~m}$ above the surface of Rongelap Island. In order to make this estimate, we accounted for the buildup of fallout on the ground as previously described and accounted for the photons emitted from all nuclides listed in Table 13. A plot of the integrated exposure versus time was given as Figure 11 . From the decay exponents derived from Bikini ash decay and the exposure-rate survey results obtained by the radsafe teams of the USS RENSHAW and the USS PHILIP, exposure rates versus time post-detonation were plotted (Figure 10) and integrated (Figure 11) for Sifo and Utirik Islands. The total integrated exposure at $\mathrm{l} \mathrm{m}$ above the surface of $S$ ifo Island was $4.4 \times 10^{-2} \mathrm{C} \mathrm{kg}^{-1}(170 \mathrm{R})$ and at Utirik Island $4.1 \times 10^{-3} \mathrm{C} \mathrm{kg}^{-1}(16 \mathrm{R})$. These exposures were for the period of time from the onset of fallout to evacuation, March 1-3, 1954.

Although our air exposure estimates at early times postdetonation differ from those of Cronkite et al. (Cr56), they are in agreement with Cronkite's whole-body and external thyroid absorbed-dose estimates. The Marshallese reported no significant deviation from routine living patterns (see interviews recorded by Sharp, Sh57). In a previous document by Greenhouse and Miltenberger ( $\mathrm{Gr} 77$ ), it was shown that external exposure inhomogeneities due to various living patterns (such as fishing in the lagoon, standing on the beach, etc.) could be accounted for by multiplying the mean exposure rate for the island at $1 \mathrm{~m}$ above the surface by a factor of 0.73 to obtain whole-body absorbeddose rate. They included in this multiplicative factor a correction for the electron density difference between $a$ ir and tissue. We used another multiplicative factor of 0.95 to convert exposure to whole-body dose. We used this additional factor to account for attenuation and buildup of the photon flux as it traversed the body. The energy spectra we assumed was the one given by Borg (BO56) for BRAVO fallout at 4 days. Thus, we estimate the external whole-body dose at Rongelap to have been $1.9 \mathrm{gray}(190 \mathrm{rad})$. This compares to 1.75 gray (175 rad) which was estimated by Cronkite et al.

\section{Radioactivity in Food, Water Supplies, and Air}

a. Activity in Cistern Hater. The main water supplies at Rongelap, eight cisterns, were reported to each contain $0.23 \mathrm{~m}$ of water during the later part of March and early April 1954 (Sh57). Water was drawn from six of these cisterns at Rongelap for gross beta analysis on March 2, 1954 (see report of the radsafe team USS PHILIP, OC68), and one other cistern was reported empty. Each 


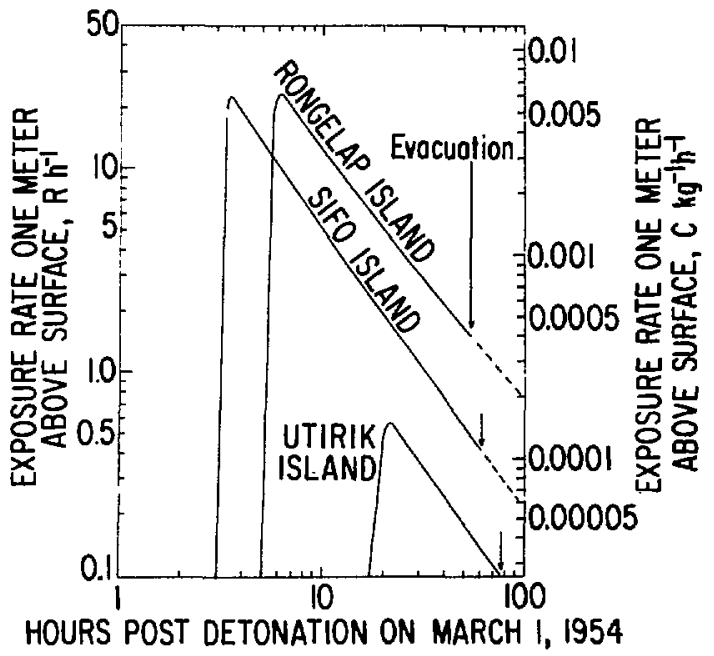

F1gure 10. Exposure-rate histories for Rongelap, Sifo, and Utirik Islands based on Bikini ash characteristics.

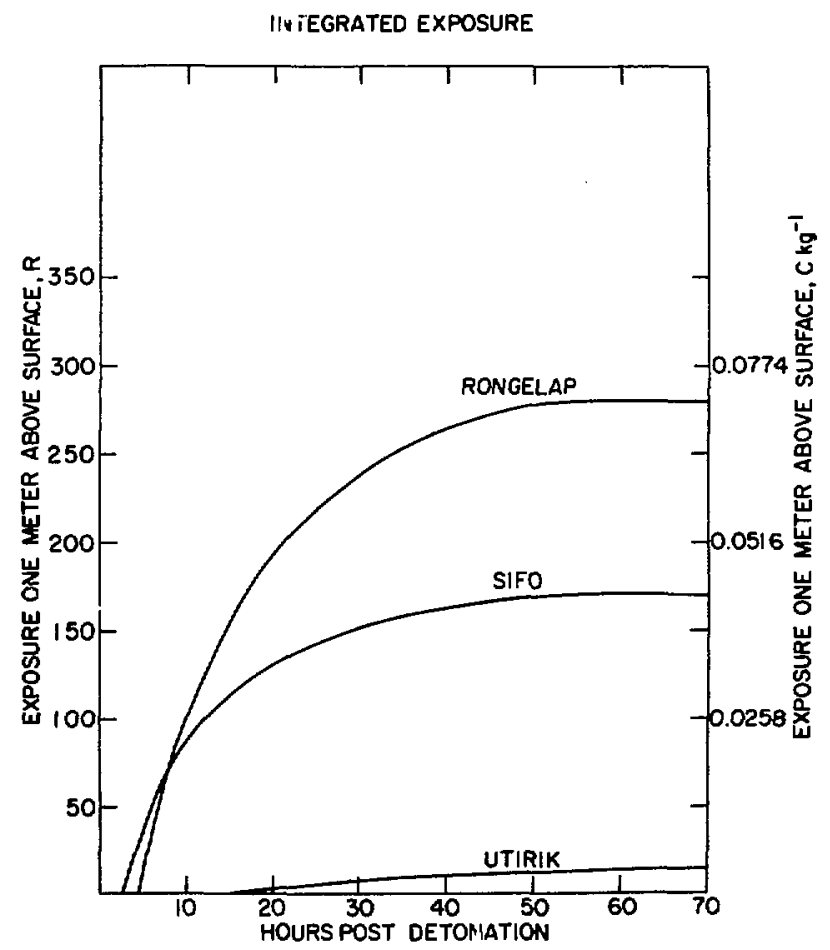

Figure 11. Integrated exposure vs time. 
cistern opening measured about $0.65 \mathrm{~m}^{2}$ and was fed by means of galvanized metal sheeting used for catching rainwater (Figure 12). A little rain was reported on the afternoon of March 1,1954 (Sh57). We assumed that the additional cistern catchment area did not contribute water or activity to the cistern.

Results of the analysis for gross beta-activity concentration in cistern water ranged from $1.8 \times 10^{5}$ to $2.0 \times 10^{6} \mathrm{~Bq} \ell^{-1}(0.005$ to $0.054 \mu \mathrm{Ci}$ $\left.\mathrm{ml}^{-1}\right)$ with a mean of $5.0 \times 10^{5} \mathrm{~Bq} \mathrm{l}^{-1}\left(0.027 \mu \mathrm{Ci} \mathrm{ml^{-1 }}\right)$ at 50 hours postdetonation (0C68). The fallout from Castle series coral surface bursts including BRAVO was reported as being barely soluble in water (Ka66). BRAvO fallout, which was collected with mixtures of rain and sea spray, lost only 20 to $50 \%$ of the iodine activity to the liquid phase (Ka66). The serviceman at Rongerik Atoll examined the terrestrial fallout under a microscope and reported that the sand-like granules were not soluble in water on the microscope slide (Sh57). Therefore, most BRAVO activity and a good portion of the radioiodine activity probably remained with the fallout particles at the bottom of a cistern.

We extrapolated the 50-hour post-detonation beta-activity concentrations back to 0.5 day post-detonation using decay characteristics for Bikini ash components. The range for gross beta-activity concentrations was $1.0 \times 10^{6}$ to $1.2 \times 10^{7} \mathrm{Bg} \ell^{-1}\left(0.027\right.$ to $\left.0.31 \mu \mathrm{Ci} \mathrm{m1^{-1 }}\right)$ and the mean was $2.9 \times 10^{6} \mathrm{~Bq} \ell^{41}$ $(0.078 \mu \mathrm{Ci} \mathrm{ml}-1)$. At $0.5 \mathrm{day}$, a total of $3.7 \times 10^{10} \mathrm{~Bq} \mathrm{~m}^{-2}\left(1 \mathrm{Ci} \mathrm{m}^{-2}\right)$ of Bikini ash gross beta activity was estimated by $u s$ as the sum of the activity of all nuclides listed in Table 13. Given the area of a cistern opening, we calculated that the average cistern contained $8.3 \mathrm{~m}^{3}$ of water if all the Bikini ash activity was in the liquid phase. This water volume would be necessary to dilute the activity to the leve 1 reported by the radsafe team. We estimate that this was about 55 times greater than the observed water volume of the cisterns as previously indicated by Sharp (Sh57). Assuming only $20 \%$ of the iodine activity in

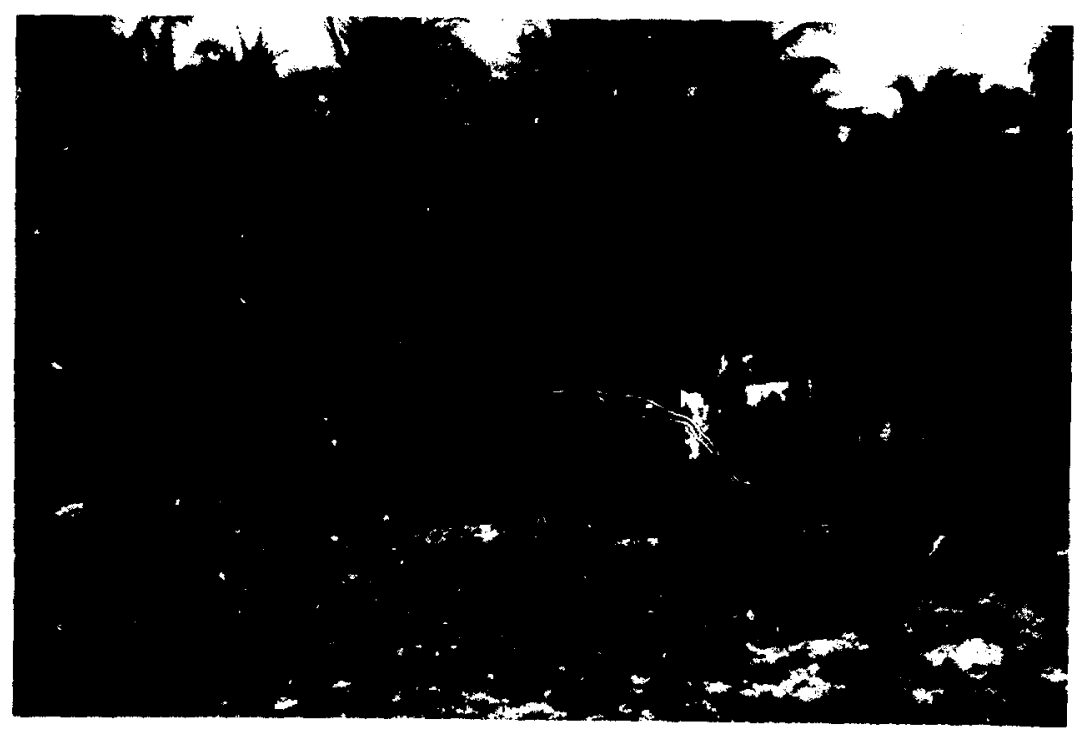

Figure 12. A cistern at Rongelap Island. 
the liquid phase (the lowest estinate reported, Ka66), no activity in the liquid phase from all other nuclides, and the appropriate activity of each iodine isotope in Bikini ash at 50 hours post-detonation, leads us to the sane estinate of cistern water content as reported by Sharp and others, about $0.15 \mathbf{m}^{3}$ (Sh57).

On the basis of 1) Bikini ash radioiodine activity per unit area estimates given in Table 13,2 ) a $20 \%$ release of iodine activity from fallout granules to cistern water, and 3) an average cistern water volume of $0.15 \mathrm{n}^{3}$, we estimated the radioiodine activity concentrations for cisterns located at Rongelap Island. A range of cistern water activity at Rongelap Island was estimated to be between 0.2 and 2 times the average values given in Table 14. We based this estimate on the range reported for gross beta-activity measurements (0C68). The instantaneous activity concentrations given in Table 14 were adjusted for the rate of buildup of activity during fallout deposition.

The activity concentration in Sifo Island cistern water was assuned by $u s$ to be 127 the values given at Rongelap. This was based on a ratio of mean exposure rate at both islands at seven hours post-detonation and the ratio of the fractions of total granule activity on the surface of fallout granules.

Rawahara reported that the water rewoved the iodine near the surface of the fallout granule (Ka66). We assumed that small granules had a greater fraction of total activity near the surface than did large granules, because of the surface-area to volume ratio. We estimated a different portion of iodine activity released from granules sized differently fron those at Rongelap by assuming spherical-shaped granules and a mean granule radius for each island.

The cisterns and wells at Utirik Island were observed to be covered as reported by the evacuation team aboard the USS RENSHAW (OC68). Interestingly, the range of cistern water activity at Utirik Island was $1.2 \times$ $10^{5}$ to $5.5 \times 10^{5} \mathrm{~Bq} \ell^{-I}\left(0.003\right.$ to $\left.0.02 \mu \mathrm{Ci} \mathrm{ml}^{-1}\right)$, as conputed for 0930 on March 3, 1954, from two different cistern water samples taken on March 9 (0668). The mean Utirik cistern water activity was about one third the mean cistern water activity reported for Rongeiap Island at the same time. The roof over each cistern apparently was not effective in preventing contamination.

We assumed that activity in the liquid phase in two cisterns would be directly proportional to the ratio of exposure rates near each cistern as well as to the ratio of the fraction of total activity on the surface of the mean granule size in each cistern. This approach leads us to expect roughly equal radioiodine activity in the liquid phase in cisterns at Rongelap and Utirik Islands at the same point in time. This was largely due to a greater proportion of activity on the surface of fallout granules in the Utirik cistern. Thus, on the basis of expected activity vo measured activity, the cistern coverings at Utirik did protect the drinking water to sone degree, perhaps reducing its activity by as much as a factor of 3 . This reduction was based on the observed average activity ratio between Utirik and Rongelap cistern water.

b. Activity Ingested with Drinking Hater. Prior to evacuation of Ronge lap, many weeks of drought were $r$ sorted by Sharp (Sh57). In the weeks pre 
Table 14

Average Estinate of Radioiodine Activity in Cistern water and Time After the BRAVO Detonation

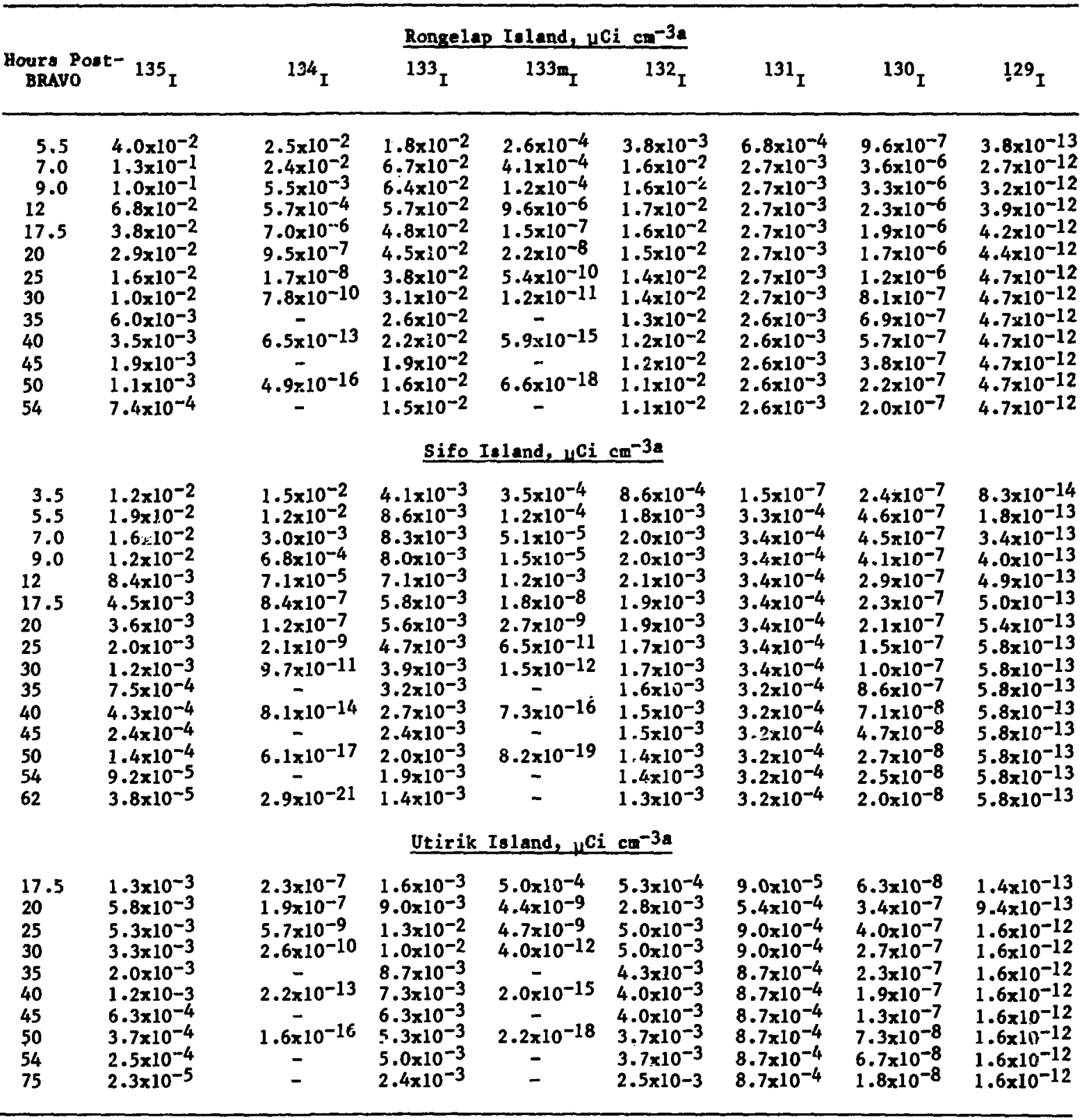

Multiply by $3.7 \times 10^{7}$ to obtain Bq $\ell^{-1}$. 
ceding the BRAVO contamination, water from cisterns was rationed to "one pint cup per person each day" (Sh57), or (assuming us liquid measure) $470 \mathrm{~cm}^{3}$ of water per person per day. This water was used to make tea and coffee and was directly ingested (Sh57). Naidu, in the late 1970s, observed an average intake of about $1000 \mathrm{~cm}^{3}$ of coconut water per day for adults, $800 \mathrm{~cm}^{3}$ for adolescents, and $500 \mathrm{~cm}^{3}$ for 1- to 3-year-old children (Na80). In addition, the Marshallese consuned coconut tree sap, about $700 \mathrm{~cm}^{3}$ per day for adults, $600 \mathrm{~cm}^{3}$, for adolescents, and $400 \mathrm{~cm}^{3}$ for $1^{-}$to 3 -year-old children (Na80). Not inciluding the water intake from ingested food and by oxidation of food, a 70-kg adult would ingest $2000 \mathrm{~cm}^{3}$ per day of fluids and a 10-year-old child $1400 \mathrm{~cm}^{3}$ per day in order to balance itormal water $1088 e s$ in a temperate clinate (ICRP74).

Therefore, it is likely that each person drank most of his or her ciaily cistern water ration of $470 \mathrm{~cm}^{3}$ in order to maintain water balance. People reported that they drank this water despite the off taste and color produced by fallout contamination (Sh57).

We assumed that $150 \mathrm{~cm}^{3}$ of water was taken with each meal. At Ronge lap Island, this was assumed to occur at 5.5 (lunch), 12 (dinner), 24 (breakfast), 30 (lunch), 38 (dinner), and 50 (breakfast) hours post-detonation. We have found no report to indicate that rationing was necessary at sifo or Utirik Island. Based on water balance, it was assumed that one pint per person per day was the cistern water intake at these islands as we11. We assumed that the $150-\mathrm{cm}^{3}$ intake of water with meals occurred at Sifo Island at the sane meal times assumed for Rongelap Island and at 57 hours (lunch) post-distonation as we11. At Utirik, we assumed that the $150-\mathrm{cm}^{3}$ mealtime cistern water intake occurred at $24,31,38,50,57,64$, and 76 hours post-detonation. Evacuation at Utirik was completed at 78 hours post-detonation (0668). These assumed cistern water intakes led to estimates of ingested radioiodine activity which are tabulated in Table 15 .

The values in Table 15 represent a conservative estimate of radioiodine activity intake from this pathway since we assuned that all activity in the liquid phase sas due only to iodine isotopes. Typically, 50 to $80 \%$ of the radioiodine would settle out of cistern water along with a good portion of the total fallout activity. Given the range of measured beta activity in each cistern on Rongelap on March 31,1954 , we estimate an upper limit to drinking water intake at twice the values in Table 15. The upper limit estinate is about $4 \%$ of the expected intake if one compares to the urine derived intake estimate. We did not consider further refinement of the cistern water pathway leading to radioiodine intake, since the result would be not an increase in the iodine intake, but rather a decrease. Thus, we would not achieve the boundary condition that iodine in urine at day-17 be accounted for.

c. Activity in Food. Preparation and consumption of food in the open was, and still is, a conmon practice among the Marshallese people; therefore, fallout was ingested directly with food. Persons interviewed at Rongelap indicate that food had a strange taste (like cement) just prior to the 1954 evacuation (Sh57). Fallout had the appearance of table salt and flour, caro powder or chalk dust, and blackened the sky as if night were approaching ( $5 \mathrm{~h} 57$ ). One fanily group reported to sharp that the only food not dusted by fallout was coconut meat and milk (Sh57). Most families reported eating in the usval outdoors style 
Table 15

Average Estimate of Activity Intake from Cistern Water

\begin{tabular}{|c|c|c|c|c|c|c|}
\hline & \multicolumn{2}{|c|}{$\begin{array}{cr}\text { Rongelap Island } \\
\mathrm{Bq} & \mu \mathrm{Ci}\end{array}$} & \multicolumn{2}{|c|}{ Sifo Island } & $\begin{array}{l}\text { Utirik } \\
\mathrm{Bq}\end{array}$ & $\begin{array}{l}\text { Island } \\
\mu C i\end{array}$ \\
\hline $\begin{array}{l}{ }^{135} \mathrm{I} \\
134 \mathrm{I} \\
133_{\mathrm{I}} \\
133 \mathrm{~m}_{\mathrm{I}} \\
132 \mathrm{I} \\
131_{\mathrm{I}}\end{array}$ & $\begin{array}{l}7.8 \times 10^{5} \\
1.4 \times 10^{5} \\
1.0 \times 10^{6} \\
1.5 \times 10^{3} \\
4.1 \times 10^{5} \\
7.8 \times 10^{4}\end{array}$ & $\begin{array}{l}21 \\
3.8 \\
28 \\
0.040 \\
11 \\
2.1\end{array}$ & $\begin{array}{l}1.7 \times 10^{5} \\
6.7 \times 10^{4} \\
1.6 \times 10^{5} \\
6.7 \times 10^{2} \\
5.9 \times 10^{4} \\
1.1 \times 10^{4}\end{array}$ & $\begin{array}{l}4.7 \\
1.8 \\
4.2 \\
0.018 \\
1.6 \\
0.29\end{array}$ & $\begin{array}{c}6.7 \times 10^{4} \\
- \\
2.6 \times 10^{5} \\
- \\
1.4 \times 10^{5} \\
3.4 \times 10^{4}\end{array}$ & $\begin{array}{c}1.8 \\
- \\
7.0 \\
- \\
3.9 \\
0.93\end{array}$ \\
\hline
\end{tabular}

and prepared foods such as cooked pumpkin, starch tubes, rice, and bread products over open campfires (see Figure 13). In addition, fish was normally dried on open air racks prior to intake.

d. Activity Ingested with Meals. Most of the activity fell at Rongelap Island during preparation of the midday and evening meals. Fallout was visible even on peoples' skin, and caused itching, sneezing, and coughing (Sh57). The living pattern of the Marshallese led to direct ingestion of BRAvO fallout in amounts which can be estimated on the basis of meal intake and if the ${ }^{131}$ I activity measured in urine is used as a normalization point. The living patterns at Utirik and Sifo were similar to those at Rongelap (Na80). No alteration in daily routine was thought to occur and no attempt at removing visible fallout from food was reported by persons evacuated from Rongelap or Sifo Islands (Sh57).

Fallout was distributed on the surface of Rongelap Island at 0.5 day post-detonation at a level of about $3.7 \times 10^{10} \mathrm{~Bq} \mathrm{~m} \mathrm{~m}^{-2}\left(1 \mathrm{Ci} \mathrm{m}^{-2}\right.$ ) (see Table 13). This was in agreement with soil sample results obtained on March 8, 1954 (0c68). On the basis of a conversion factor given by the persons doing the soil analysis (0C68), the measured soil specific activity was converted to activity per unit area at 0.5 day post-detonation for comparison purposes. Their value for Rongelap Island based on four samples, was $2.0 \times 10^{10} \pm 2.7 \times 10^{10} \mathrm{~Bq} \mathrm{~m}^{-2}$ $\left(0.53 \pm 0.72 \mathrm{Ci} \mathrm{m}^{-2}\right)$.

Random soil sampling was done at Utirik Island, Sifo Island, Eniwetak Island, and other islands at Rongelap, Ailingnae, Utirik, and Rongerik Ato11s (OC68). At the end of fallout deposition at Utirik Island, which we estimated to be 1.5 days post detonation, the surface activity based on one soil sample was $1.0 \times 10^{10} \mathrm{~Bq} \mathrm{~m}^{-2}\left(0.27 \mathrm{Ci} \mathrm{m}^{-2}\right)$. This very large result does not agree with estimates we derive from exposure-rate measurements. At this activity per unit area, the exposure rate 1.5 days post-detonation should have been $8.3 \times 10^{-4} \mathrm{C} \mathrm{kg}^{-1} \mathrm{~h}^{-1}\left(3.2 \mathrm{R} \mathrm{h}^{-1}\right)$, however, the island average was estimated 

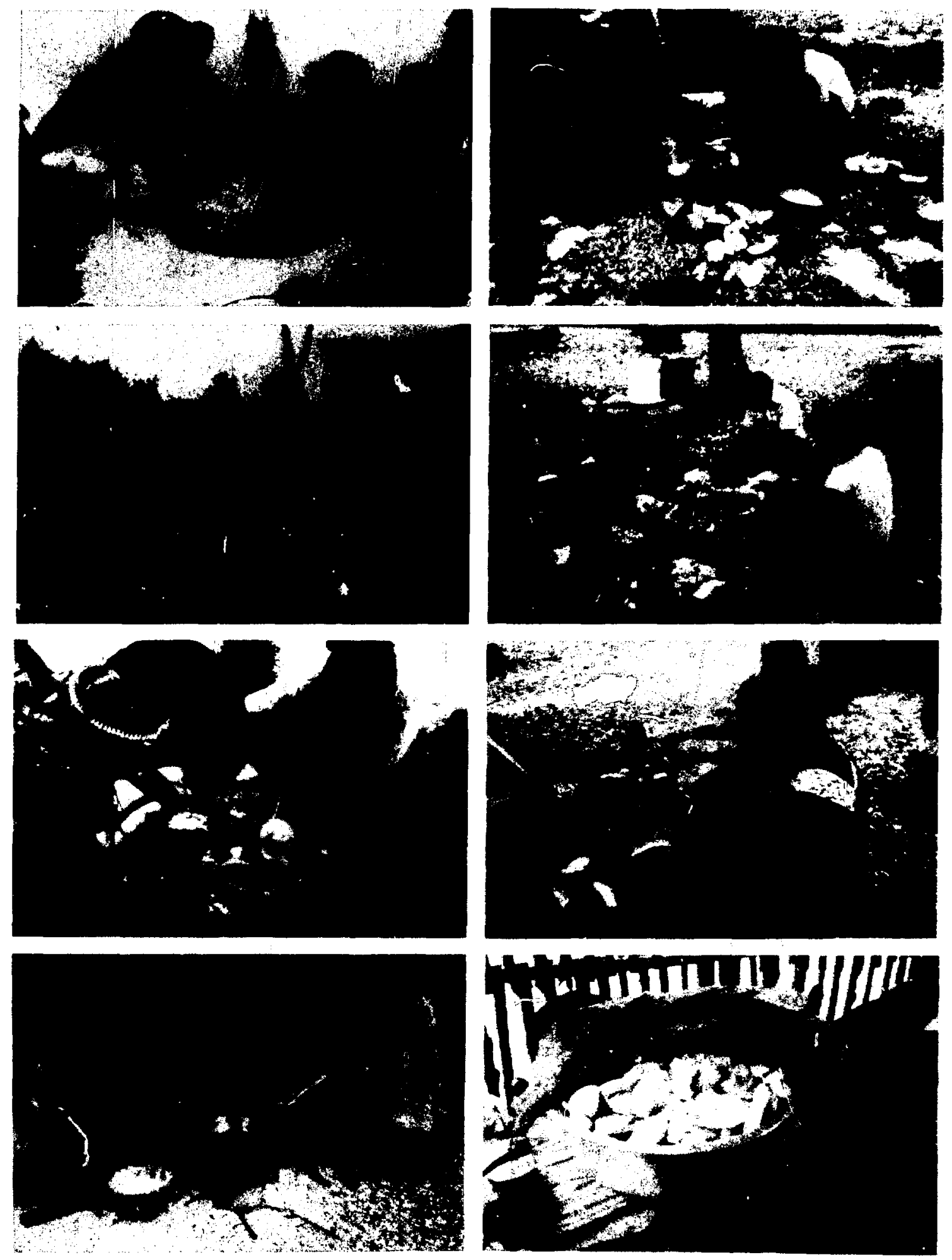

Figure 13. Food prepared and consumed outdoors. 

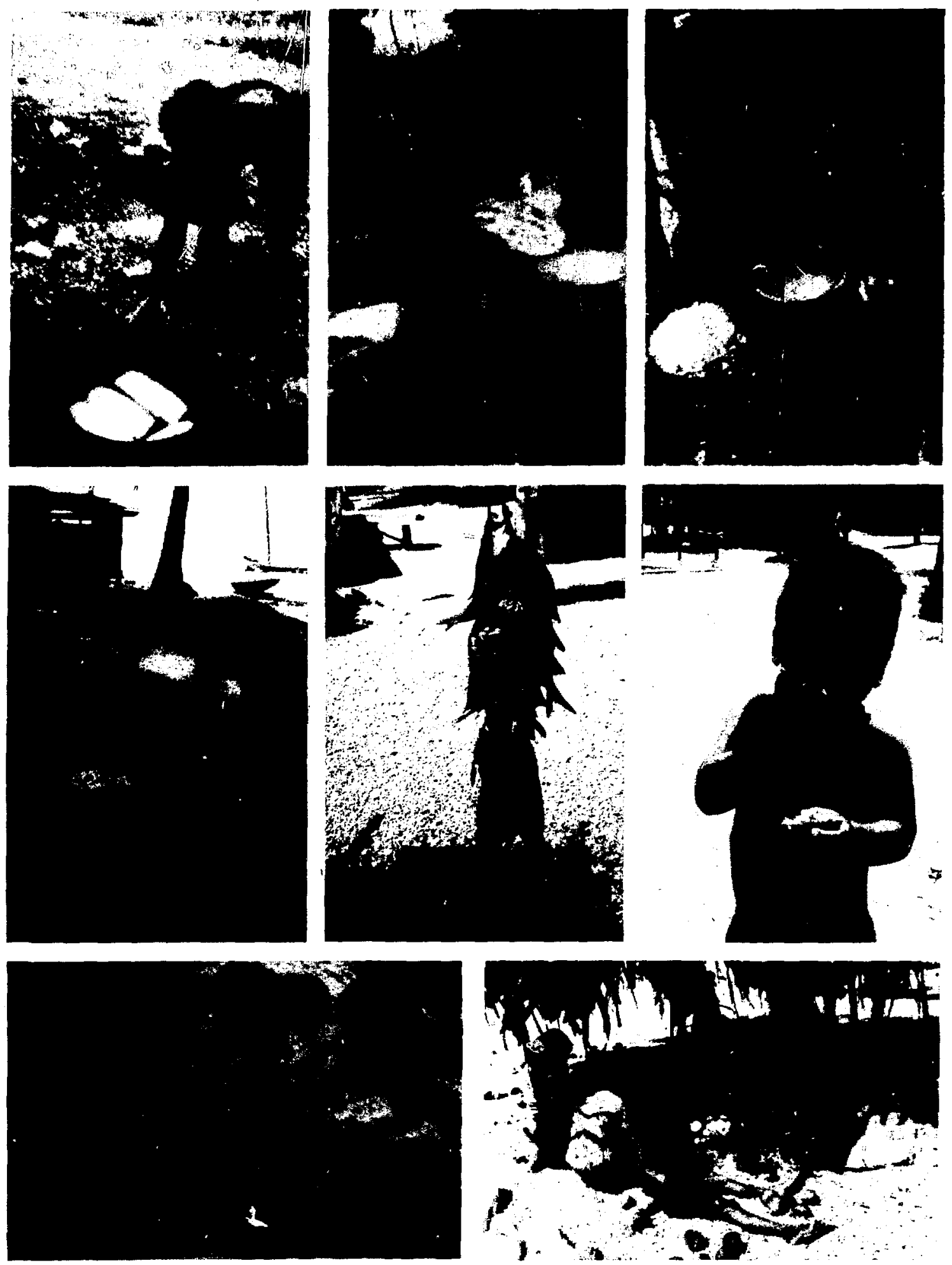

Figure 13. (Continued.) 
from the survey to be $7.2 \times 10^{-5} \mathrm{C} \mathrm{kg}^{-1} \mathrm{~h}^{-1}\left(0.28 \mathrm{R} \mathrm{h}^{-1}\right)(0 \mathrm{C68})$. We recognize that soil analysis results exhibit orders of magnitude variations even when soil is taken from near?y the same spot (0668). We assumed the exposure-rate surveys were correct for Utirik and we ignored this one soil activity result wich would lead us to estimate very high thyroid doses. At Sifo Island, the fallout cloud passed by at 0.33 day post-detonation. The activity per unit area at $s$ ifo, measured with one soil sample, was $1.2 \times 10^{9} \mathrm{~Bq} \mathrm{a}^{-2}\left(0.032 \mathrm{Ci}^{-2}\right)$. At Eniwetak Island, the BRAVO cloud was estinated to have passed by at 0.67 day postdetonation and the measured surface activity at that time, based on two samples, was $1.2 \times 10^{10} \pm 7.8 \times 10^{9} \mathrm{~Bq} \mathrm{~m}-2\left(0.32 \pm 0.21 \mathrm{Ci} \mathrm{m}^{-2}\right)$.

In Table 16 we tabulated activity per unit area and time postdetonation for Rongelap Island for nuclides contributing significantly to thyroid dose. We based this tabulation on Bikini ash nuclide composition and we normalized the activity per unit area to the exposure-rate surveys made by the survey teams. In this table, the instantaneous surface activities during fal1out deposition reflect the buildup discussed earlier. We estieated the activity per unit area of selected nuclides at Utirik and Sifo Islands by using the ratio of the exposure rates at Rongelap and Utirik. The exposure-rate ratio for Rongelap and Sifo Islands was 3.0 to 1.0 and for Rongelap and Utirik Islands, 9.5 to 1.0 after the cessation of fallout.

Although BRAVO debris was not highly soluble in water, calciw carbonate and hydrated calcium oxide (the satrix in which BRAvo fallout was entrained) were both highly soluble in acid (Co72). Therefore, ingestion of BRAVO debris resulted in release of radioiodines and other nuclides trapped in the granules because of the acid enviroment of the stomach. The mass and volume of BRAVO fallout granules were insignificant relative to the nornal anourt of food eaten per meal, which was about $400 \mathrm{~g}$ for adults (Bv66). The mass of BRAVO fallout per square meter at Rongelap Ialand was $4.4 \mathrm{~g}$ and the volune of this mass was $1.9 \mathrm{~cm}^{3}$, about four tenths the volume of a teaspoon. These estimates at Utirik Island were $0.46 \mathrm{~g} \mathrm{~m}^{-2}$ and $0.20 \mathrm{~cm}^{3} \mathrm{~m}^{-2}$. For Sifo Island it was $1.5 \mathrm{~g} \mathrm{~m}^{-2}$ and $0.48 \mathrm{~cm}^{3} \mathrm{~m}^{-2}$. These mass and volume per unit area estiwates were for the time at which all fallout was on the ground. They were based on the epecific activity and specific gravity of Bikini ash measured on Apri1 23, 1954 (Ki56). The values for Utirik and Sifo Islands were estinated by ratio of their exposure rate to that at Rongelap Island after fallout cessation at the sane time.

The outside area used to prepare food for the midday or evening meals at Rongelap may have been within several square weters for a family (see Figure 13). Boiling and frying were done over an open fire fueled by coconut she11s. Green breadfruit, fish, and nuts were roasted over a coconut-she11- or husk-fueled fire, when the husk had turned to coals. Ground ovens, used for baking breadfruit, were normally protected with banana leaf coverings against dirt and dust ( $\mathrm{NaSO}$ ). These outdoor preparation and cooking modes allowed significant amounts of BRAVO debris to be mixed with food.

The amount of fallout dust ingested per meal would depend upon the amount that fell into utensils and plates during preparation and during consumtion. Resuspension and subsequent deposition on food and preparation of food on 
Table 16

Surface Activity and Times After BRAvo

\begin{tabular}{|c|c|c|c|c|c|c|c|c|c|c|c|c|c|c|c|}
\hline \multirow[b]{2}{*}{ Nuclide } & \multicolumn{15}{|c|}{ Rongelap Is land, $\mu \mathrm{Ci}^{-2 a}$} \\
\hline & $\begin{array}{l}\text { Hours Post } \\
3.5\end{array}$ & $\begin{array}{l}\text { t Detonation } \\
5.5\end{array}$ & 7.0 & 9.0 & 12 & 17.5 & 20 & 25 & 30 & 35 & 40 & 45 & 50 & 54 & 75 \\
\hline $\begin{array}{l}135 \mathrm{I} \\
134 \mathrm{I} \\
133 \mathrm{I} \\
132 \mathrm{I} \\
131 \mathrm{I} \\
132 \mathrm{Te} \\
131 \mathrm{Ie}\end{array}$ & $\begin{array}{l}- \\
- \\
- \\
- \\
- \\
-\end{array}$ & $\begin{array}{l}4.5 \times 10^{4} \\
2.9 \times 10^{4} \\
2.1 \times 10^{4} \\
4.4 \times 10^{3} \\
7.8 \times 10^{2} \\
4.8 \times 10^{3} \\
9.1 \times 10^{2}\end{array}$ & $\begin{array}{l}1.5 \times 10^{5} \\
2.8 \times 10^{4} \\
7.7 \times 10^{4} \\
1.8 \times 10^{4} \\
3.1 \times 10^{3} \\
1.9 \times 10^{4} \\
3.5 \times 10^{3}\end{array}$ & $\begin{array}{l}1.1 \times 10^{5} \\
6.3 \times 10^{3} \\
7.3 \times 10^{4} \\
1.8 \times 10^{4} \\
3.1 \times 10^{3} \\
1.8 \times 10^{4} \\
3.3 \times 10^{3}\end{array}$ & $\begin{array}{l}7.8 \times 10^{4} \\
6.5 \times 10^{2} \\
6.5 \times 10^{4} \\
1.9 \times 10^{4} \\
3.1 \times 10^{3} \\
1.8 \times 10^{4} \\
3.1 \times 10^{3}\end{array}$ & $\begin{array}{l}4.4 \times 10^{4} \\
8.0 \times 10^{0} \\
5.5 \times 10^{4} \\
1.8 \times 10^{4} \\
3.1 \times 10^{3} \\
1.7 \times 10^{4} \\
2.7 \times 10^{3}\end{array}$ & $\begin{array}{l}3.3 \times 10^{4} \\
1.1 \times 10^{0} \\
5.2 \times 10^{4} \\
1.7 \times 10^{4} \\
3.1 \times 10^{3} \\
1.7 \times 10^{4} \\
2.6 \times 10^{3}\end{array}$ & $\begin{array}{l}1.8 \times 10^{4} \\
2.0 \times 10^{-2} \\
4.4 \times 10^{4} \\
1.6 \times 10^{4} \\
3.1 \times 10^{3} \\
1.6 \times 10^{4} \\
2.3 \times 10^{3}\end{array}$ & $\begin{array}{l}1.1 \times 10^{4} \\
8.9 \times 10^{-4} \\
3.6 \times 10^{4} \\
1.5 \times 10^{4} \\
3.1 \times 10^{3} \\
1.5 \times 10^{4} \\
2.0 \times 10^{3}\end{array}$ & $\begin{array}{c}6.9 \times 10^{3} \\
- \\
3.0 \times 10^{4} \\
1.5 \times 10^{4} \\
3.0 \times 10^{3} \\
1.5 \times 10^{4} \\
1.8 \times 10^{3}\end{array}$ & $\begin{array}{c}4.0 \times 10^{3} \\
- \\
2.5 \times 10^{4} \\
1.4 \times 10^{4} \\
3.0 \times 10^{3} \\
1.4 \times 10^{4} \\
1.6 \times 10^{3}\end{array}$ & $\begin{array}{c}2.2 \times 10^{3} \\
- \\
2.2 \times 10^{4} \\
1.4 \times 10^{4} \\
3.0 \times 10^{3} \\
1.4 \times 10^{4} \\
1.4 \times 10^{3}\end{array}$ & $\begin{array}{c}1.3 \times 10^{3} \\
- \\
1.8 \times 10^{4} \\
1.3 \times 10^{4} \\
3.0 \times 10^{3} \\
1.3 \times 10^{4} \\
1.3 \times 10^{3}\end{array}$ & $\begin{array}{r}3.6 \times 10^{2} \\
- \\
1.7 \times 10^{4} \\
1.2 \times 10^{4} \\
3.0 \times 10^{3} \\
1.2 \times 10^{4} \\
1.2 \times 10^{3}\end{array}$ & $\begin{array}{c}7.9 \times 10^{1} \\
- \\
8.3 \times 10^{3} \\
1.0 \times 10^{4} \\
3.0 \times 10^{3} \\
1.0 \times 10^{4} \\
7.2 \times 10^{2}\end{array}$ \\
\hline \multicolumn{16}{|c|}{ Sifo Island, $\mu \mathrm{C}_{i} \mathrm{~m}^{-2 \Omega}$} \\
\hline $\begin{array}{l}135 \mathrm{I} \\
134 \mathrm{I} \\
133 \mathrm{I} \\
132 \mathrm{I} \\
131 \mathrm{I} \\
132 \mathrm{Te} \\
131 \mathrm{me}_{\mathrm{Te}}\end{array}$ & $\begin{array}{l}3.8 \times 10^{4} \\
4.9 \times 10^{4} \\
1.3 \times 10^{4} \\
2.8 \times 10^{3} \\
4.5 \times 10^{2} \\
2.9 \times 10^{3} \\
5.7 \times 10^{2}\end{array}$ & $\begin{array}{l}6.0 \times 10^{4} \\
3.9 \times 10^{4} \\
2.8 \times 10^{4} \\
5.9 \times 10^{3} \\
1.0 \times 10^{3} \\
6.4 \times 10^{3} \\
1.2 \times 10^{3}\end{array}$ & $\begin{array}{l}5.0 \times 10^{4} \\
9.3 \times 10^{3} \\
2.5 \times 10^{4} \\
6.0 \times 10^{3} \\
1.0 \times 10^{3} \\
6.3 \times 10^{3} \\
1.2 \times 10^{3}\end{array}$ & $\begin{array}{l}3.6 \times 10^{4} \\
2.1 \times 10^{3} \\
2.4 \times 10^{4} \\
6.0 \times 10^{3} \\
1.0 \times 10^{3} \\
6.0 \times 10^{3} \\
1.1 \times 10^{3}\end{array}$ & $\begin{array}{l}2.6 \times 10^{4} \\
2.2 \times 10^{2} \\
2.2 \times 10^{4} \\
6.3 \times 10^{3} \\
1.0 \times 10^{3} \\
6.0 \times 10^{3} \\
1.0 \times 10^{3}\end{array}$ & $\begin{array}{l}1.5 \times 10^{4} \\
2.6 \times 10^{0} \\
1.8 \times 10^{4} \\
6.0 \times 10^{3} \\
1.0 \times 10^{3} \\
5.6 \times 10^{3} \\
8.9 \times 10^{2}\end{array}$ & $\begin{array}{l}1.1 \times 10^{4} \\
3.6 \times 10^{-1} \\
1.7 \times 10^{4} \\
5.6 \times 10^{3} \\
1.0 \times 10^{3} \\
5.6 \times 10^{3} \\
8.6 \times 10^{2}\end{array}$ & $\begin{array}{l}6.0 \times 10^{3} \\
6.6 \times 10^{-3} \\
1.5 \times 10^{4} \\
5.3 \times 10^{3} \\
1.0 \times 10^{3} \\
5.3 \times 10^{3} \\
7.6 \times 10^{2}\end{array}$ & $\begin{array}{l}3.6 \times 10^{3} \\
2.9 \times 10^{-4} \\
1.2 \times 10^{4} \\
5.0 \times 10^{3} \\
1.0 \times 10^{3} \\
5.0 \times 10^{3} \\
6.6 \times 10^{2}\end{array}$ & $\begin{array}{l}2.3 \times 10^{3} \\
- \\
9.9 \times 10^{3} \\
5.0 \times 10^{3} \\
9.9 \times 10^{2} \\
5.0 \times 10^{3} \\
6.0 \times 10^{2}\end{array}$ & $\begin{array}{c}1.3 \times 10^{3} \\
-- \\
8.3 \times 10^{3} \\
4.6 \times 10^{3} \\
9.9 \times 10^{2} \\
4.6 \times 10^{3} \\
5.3 \times 10^{2}\end{array}$ & $\begin{array}{r}7.3 \times 10^{2} \\
- \\
7.3 \times 10^{3} \\
4.6 \times 10^{3} \\
9.9 \times 10^{2} \\
4.6 \times 10^{3} \\
4.6 \times 10^{2}\end{array}$ & $\begin{array}{l}4.3 \times 10^{2} \\
- \\
6.0 \times 10^{3} \\
4.3 \times 10^{3} \\
9.9 \times 10^{2} \\
4.3 \times 10^{3} \\
4.3 \times 10^{2}\end{array}$ & $\begin{array}{c}1.2 \times 10^{2} \\
- \\
5.6 \times 10^{3} \\
4.0 \times 10^{3} \\
9.9 \times 10^{2} \\
4.0 \times 10^{3} \\
4.0 \times 10^{2}\end{array}$ & $\begin{array}{c}2.6 \times 10^{1} \\
2.7 \times 10^{3} \\
3.3 \times 10^{3} \\
9.9 \times 10^{2} \\
3.3 \times 10^{3} \\
2.4 \times 10^{2}\end{array}$ \\
\hline \multicolumn{16}{|c|}{ Utirik Island, $\mu \mathrm{Ci}^{-2 \mathrm{a}}$} \\
\hline
\end{tabular}

Multiply by $3.7 \times 10^{4}$ to obtain Bq $\mathrm{m}^{-2}$. 
dusty surfaces would be secondary pathways. During the midday meal at Rongelap Island, BRAvo dust probably fell directly onto plates and on the surfaces of fish which were drying in the open. The area of one plate exposed to BRAvo fa11out plus the area of a small fish is approximately $0.04 \mathrm{~m}^{2}$. If a 30 -minute lunch interval beginning at 5 hours post-detonation was assumed to be the plate and fish exposure interval to dust, then about $40 \mathrm{mg}$ would fall on this eating area at Rongelap Island. During the preparation of the evening weal, about 0.1 $\mathrm{m}^{2}$ of surface area was assumed as the family food preparation area exposed to dust during fallout deposition. On the average, each family was estimated to consist of about 4.5 people (Sh57). Therefore an additional $100 \mathrm{mg}$ of BRAvO debris per family member was estimated to be consumed with the evening meal at 12 hours post-detonation.

As indicated by our reassessment of the urine result, $3.4 \times 10^{6}$ Bq (93 $\mu \mathrm{Ci}$ ) intake of ${ }^{131_{I}}$ was estimated on the basis of measured $131_{I}$ in urine on day 17. This was assumed to be a total per adult ingestion intake of about $1.1 \times 10^{6} \mathrm{~Bq}(30 \mu \mathrm{Ci})$ at 5.5 hours post-detonation and $2.2 \times 10^{6} \mathrm{~Bq}(60 \mu \mathrm{Ci})$ at 12 hours post-detonation. Therefore, intake with midday and evening meals provided us with a reasonable pathway in terms of the nass of fallout ingested since $140 \mathrm{mg}$ corresponded to $3.3 \times 10^{6} \mathrm{~Bq}(90 \mu \mathrm{Ci})$ of $131 \mathrm{I}$.

In Table 17 we have presented the estimated activity intake (with meals) of selected nuclides at Rongelap Island. An adult male was assumed to take in $3.4 \times 10^{6} \mathrm{~Bq}(93 \mu \mathrm{Ci})$ of $131_{\mathrm{I}}$ in order to normalize with urine data. Other nuclides were estimated by normalizing the ${ }^{13} 1_{\text {I }}$ intake to Bikini ash composition which, in turn, was normalized to exposure-rate measurenents. Activity intake with meals was modified to agree with meal intakes appropriate for body weight for the different age members of the exposed populations. This modification was based on an exponential relationship between total element intake and body weight which we derived from data tabulated in the ICRP Publication 23, Reference Man (ICRP74).

Activity would have been ingested directly with meals at Utirik Island during breakfast, lunch, and dinner on March 2, 1954, due to fallout on plates, on food preparation areas, and on the food itself. As mentioned previously, Sharp reported that fallout particles were not visible to the eye at Utirik Island (0C68). Fallout activity was measured in cisterns even though cisterns were reported as covered, which indicated to us that BRAVO dust may have contaminated the surface of covered food. Essentially, our estimates indicate that the majority of the BRAVO activity fell during the time breakfast was prepared and exten. Assuming the same food eating and preparation areas as at Rongelsp, and the same family size, then about 30 mg of BRAVO dust was ingested with the breakfast meal at 24 hours post-detonation.

Resuspension followed by redeposition was considered secondary to direct deposition prior to and during breakfast. Our estinates of particle deposition velocity and reports of resuspension factors (ICRP80) indicate that the entire fallout would have to be resuspended into the air many times over in order to make resuspension an important pathway for internal thyroid dose. Dust falling from the cloud and ingested with lunch and evening meals at Utirik was 


\begin{tabular}{|c|c|c|c|c|c|c|c|c|}
\hline \multicolumn{9}{|c|}{ Table 17} \\
\hline \multicolumn{9}{|c|}{ Average Estimate of Activity Intake with Meals } \\
\hline \multicolumn{9}{|c|}{ Rongelap Island, $\mu \mathrm{Ci}^{\mathrm{a}}$} \\
\hline Age & $\begin{array}{l}\text { Body } \\
\text { Weight, kg }\end{array}$ & ${ }^{135} I$ & ${ }^{134} I$ & ${ }^{133} I$ & ${ }^{132} I$ & ${ }^{131} \mathrm{I}$ & ${ }^{132} \mathrm{Te}$ & $131 n_{T}$ \\
\hline $\begin{array}{l}\text { Adult Male } \\
\text { Adu1t Female } \\
\text { Fourteen-Year-01d } \\
\text { Twe lve-Year-01d } \\
\text { Nine-Year-01d } \\
\text { Six-Year-01d } \\
\text { One-Year-01d }\end{array}$ & $\begin{array}{l}70 \\
58 \\
50 \\
40 \\
30 \\
20 \\
10\end{array}$ & $\begin{array}{l}3400 \\
3000 \\
2800 \\
2500 \\
2300 \\
2100 \\
1900\end{array}$ & $\begin{array}{r}1200 \\
1000 \\
980 \\
890 \\
800 \\
720 \\
660\end{array}$ & $\begin{array}{l}2100 \\
1800 \\
1700 \\
1600 \\
1400 \\
1300 \\
1200\end{array}$ & $\begin{array}{l}550 \\
480 \\
450 \\
410 \\
370 \\
330 \\
300\end{array}$ & $\begin{array}{l}93 \\
81 \\
76 \\
69 \\
62 \\
56 \\
51\end{array}$ & $\begin{array}{l}550 \\
480 \\
450 \\
410 \\
370 \\
330 \\
300\end{array}$ & $\begin{array}{l}80 \\
70 \\
66 \\
59 \\
54 \\
48 \\
44\end{array}$ \\
\hline \multicolumn{9}{|c|}{ Utirik Island, $\mu \mathrm{Ci}$} \\
\hline $\begin{array}{l}\text { Adult Male } \\
\text { Adult Female }\end{array}$ & $\begin{array}{l}70 \\
58\end{array}$ & $\begin{array}{l}140 \\
120\end{array}$ & $\begin{array}{l}0.00028 \\
0 . . J 024\end{array}$ & $\begin{array}{l}280 \\
240\end{array}$ & $\begin{array}{r}100 \\
87\end{array}$ & $\begin{array}{l}20 \\
17\end{array}$ & $\begin{array}{r}100 \\
87\end{array}$ & $\begin{array}{l}15 \\
13\end{array}$ \\
\hline $\begin{array}{l}\text { Fourteen-Year-01d } \\
\text { TweIve-Year-01d }\end{array}$ & $\begin{array}{l}50 \\
40\end{array}$ & $\begin{array}{l}115 \\
100\end{array}$ & $\begin{array}{l}0.00023 \\
0.00021\end{array}$ & $\begin{array}{l}230 \\
210\end{array}$ & $\begin{array}{l}82 \\
74\end{array}$ & $\begin{array}{l}16 \\
15\end{array}$ & $\begin{array}{l}82 \\
74\end{array}$ & $\begin{array}{l}12 \\
11\end{array}$ \\
\hline $\begin{array}{l}\text { Nine-Year-01d } \\
\text { Six-Year-01d }\end{array}$ & $\begin{array}{l}30 \\
20\end{array}$ & $\begin{array}{l}94 \\
84\end{array}$ & $\begin{array}{l}0.00019 \\
0.00017\end{array}$ & $\begin{array}{l}190 \\
170\end{array}$ & $\begin{array}{l}67 \\
60\end{array}$ & $\begin{array}{l}13 \\
12\end{array}$ & $\begin{array}{l}67 \\
60\end{array}$ & $\begin{array}{r}10 \\
9\end{array}$ \\
\hline One-Year-0ld & 10 & 77 & 0.00015 & 150 & 55 & 11 & 55 & 8 \\
\hline \multicolumn{9}{|c|}{ Sifo Island, $\mu \mathrm{Ci}$} \\
\hline $\begin{array}{l}\text { Adult Male } \\
\text { Adult Female } \\
\text { Fourteen-Year-01d } \\
\text { Twe lve-Year-01d } \\
\text { Nine-Year-0ld } \\
\text { Six-Year-01d } \\
\text { One-Year-01d }\end{array}$ & $\begin{array}{l}70 \\
58 \\
50 \\
40 \\
30 \\
20 \\
10\end{array}$ & $\begin{array}{r}1200 \\
1000 \\
980 \\
890 \\
800 \\
720 \\
660\end{array}$ & $\begin{array}{l}780 \\
670 \\
640 \\
580 \\
520 \\
470 \\
430\end{array}$ & $\begin{array}{l}560 \\
490 \\
460 \\
410 \\
380 \\
340 \\
310\end{array}$ & $\begin{array}{r}120 \\
100 \\
98 \\
89 \\
80 \\
72 \\
66\end{array}$ & $\begin{array}{l}20 \\
17 \\
16 \\
15 \\
13 \\
12 \\
11\end{array}$ & $\begin{array}{r}130 \\
115 \\
110 \\
97 \\
87 \\
78 \\
72\end{array}$ & $\begin{array}{l}24 \\
21 \\
20 \\
18 \\
16 \\
14 \\
13\end{array}$ \\
\hline
\end{tabular}

a Multiply by $3.7 \times 10^{4}$ to obtain Bq. 
not considered, since fallout activity in the air would have ceased substantially by those times.

At Sifo Island, most of the fallout fell in one midaorning hour between breakfast and lunch times. Assuming the same food preparation area as at Rongelap Island, but no deposition on plates while eating, values for intake were estimated. We assumed that $60 \mathrm{mg}$ of BRAVO dust was ingested at 5.5 hours post-detonation. These dust particles would have been large, 320 micrometers average size, and visible on food prepapation surfaces.

e. Activity Concentrations in Air. Mean air concentration estinates of activity of selected nuclides were based on fallout deposition rates. The percent of activity deposited per minute at various times at Rongelap Island was estimated by us from Eq. (2). Fall velocity corresponding to granule size was taken from Figure 8 of Holland's report (Ho63). We used an estinate of fall velocity because we did not know the height of the colum of fallout over each island.

Air activity concentrations at various times were assumed by us to be 1) directly proportional to the fraction of total activity deposited per minute, 2) directly proportional to the total activity on the ground at the end of fallout (decay corrected back to various points in time), and 3 ) inversely proportional to fall velocity of granules. We applied these same assumptions to surface activity results for Sifo and Utirik Islands as well. Our values for air concentration at all three islands and times post-BRAVO detonation are tabulated in Table 18. The cumulated air activity concentrations for Rongelap Island which we derived from Bikini ash were about one third the cumlated air activity concentration results of Peterson (Pe81).

The air activity concentrations for Utirik Island relative to those at Rongelap Island might be expected to be less because of the exposurerate differences that were observed and because of greater dispersion of the fallout cloud. The fall velocity of a granule corresponding to the activity median size was greater by a factor of 95 at Rongelap Island than at Utirik Island, while the exposure rate after deposition differed by only a factor of 9.5 . If one hypothesizes that the deposition intervals at both islands were the same, and the air activity concentrations were equal, then 95 times less exposure rate at Utirik Island would be anticipated, not 9.5. The fallout cloud duration at Utirik was 2 to 3 times longer than at Rongelap based on granule size considerations. However, it was not long enough to account for the measured exposurerate results. Therefore, the air concentration at Utirik Island mist have been greater than at Rongelap (see ${ }^{131} \mathrm{I}$, Table 18). Given that fallout was not visible and exposure-rate measurements were accurate, longer fallout duration and higher air concentrations at Utirik relative to Rongelap were likely. The total fallout activity on the surface of Rongelap Island was still ten times greater than at Utirik Island, largely as a regult of the greater rate at which granules fell to the surface of Rongelap.

f. Activity Intake By Inhalation. Airborne activity intakes were dependent upon breathing rate of individuals during fallout cloud passage. We assumed breathing rate to be proportional to body mass as derived from reference 
Table 18

Air Activity Concentration of Selected Nuclides

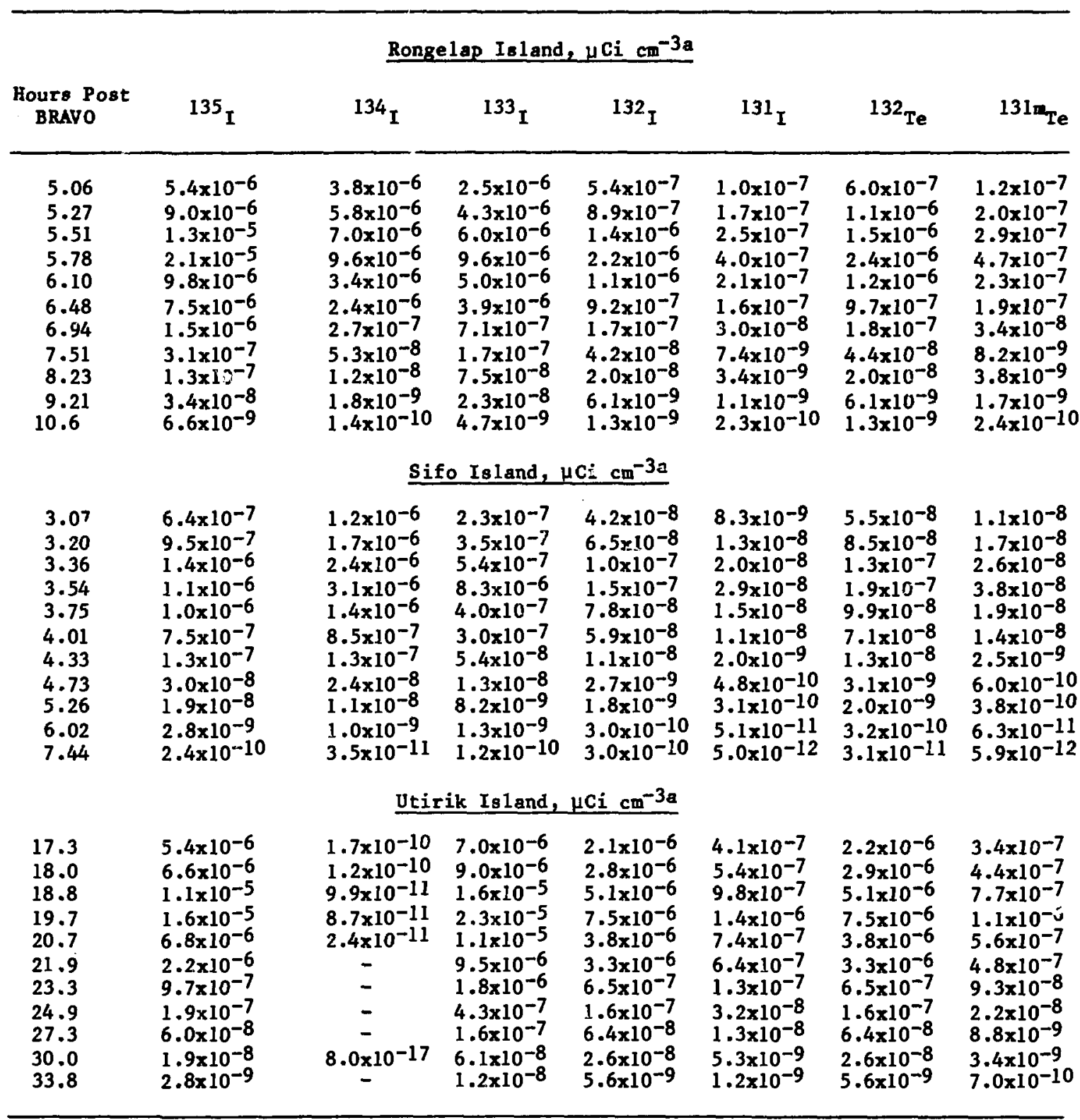

aMu1tiply by $3.7 \times 10^{10}$ to obtain Bq $\mathrm{m}^{-3}$. 
data for persons weighing less than $58 \mathrm{~kg}$ (ICRP74). Adult reference values for breathing rate (ICRP74) were assumed for Marshallese adults regardless of adult body mass. At Rongelap Island, BRAVo debris passed during the afternoon, a period of light physical activity for the population. At Utirik Island, the debris passed during the night, a period of resting. At sifo Island, a period of light physical activity was assumed in order to estimate breathing rate during the morning people were exposed to the fallout cloud. Values for airborne activity intake were compiled and are given in Table 19.

On the basis of urine results for ${ }^{131} \mathrm{I}$, we concluded that inhalation could not account for the estimated activity intake for ${ }^{131}$ I. In fact, lethal external exposure rates would have to accompany significant radioiodine intakes if inhalation of initial cloud fallout were the dominant intake pathway leading to the urine activity excreted on day 17. The other alternative, resuspension of fallout, would require the air concentrations produced by the cloud itself to be resuspended $? 00$ times over.

g. Total Activity Intake. Total activity intake and corresponding age were tabulated in Table 20 which we compiled on the basis of Tables 15, 17, and 19. We assumed that newborn babies inhaled activity at Rongelap and Utirik Islands; no newborns were reported at Sifo Island (Co74). We assumed that newborns from Rongelap and Utirik ingested $850 \mathrm{ml}$ of breast milk per day (ICRP74) for 3 days post-detonation. A fraction of $10^{-5}$ per ml of adult female breast milk was assumed to be the fraction of mother's intake of iodine which was transferred to the newborn (Ma81). Iodine decay between the time of intake for the mother and the time of intake for the newborn was neglected since we assumed breast milk to be part of the early excretion pathway out of the mother's body. Radioiodine excreted from the long-term cleirance compartments was considered insignificant relative to total radioiodine cleared in the short term (Ma81).

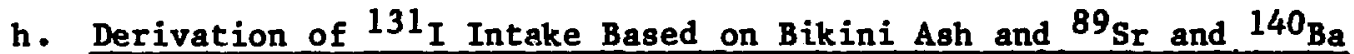
in Urine on Day 45 Post-Detonation. Cronkite (Cr56) reported ${ }^{89} \mathrm{Sr}$ and $140 \mathrm{Ba}$ urine activity excretion on day 45 post-detonation for six adults from Rongelap Island. The mean urine activity excreted on day 45 was $8.9 \mathrm{~Bq}\left(2.4 \times 10^{-4} \mu \mathrm{Ci}\right)$ of ${ }^{89} \mathrm{Sr}$ and $2.2 \mathrm{~Bq}\left(6.0 \times 10^{-5} \mathrm{\mu Ci}\right)$ of $140 \mathrm{Ba}$. Whole-body retention functions given by ICRP (ICRP72) for injection of strontium and barium are

$R_{S I}(t)=0.60 e^{-0.25 t}+0.299(t+0.20)^{-0.18}\left(0.555 e^{-6.5 \times 10^{-5} t}+0.445 e^{-2.6 \times 10^{-4} t}\right)$,

$R_{B a}(t)=0.38 e^{-0.75 t}+0.191(t+0.007)^{-0.237}\left(0.564 e^{-1.09 \times 10^{-4} t}+0.436 e^{-4.36 \times 10^{-4} t}\right)$,

where $t$ is in days and $R(t)$ is the injected fraction remaining on day $t$. The fecal-to-urine ratios for excretion of injected $\mathrm{Sr}$ and $\mathrm{Ba}$ were 0.25 and 9.0 , respectively (ICRP72). Correcting for 45 days of decay, the estimated activities injected into the systemic region of the body were $2.3 \times 10^{4} \mathrm{~Bq}(0.61 \mu \mathrm{Ci})$ and $6.1 \times 10^{5} \mathrm{~Bq}(16.4 \mu \mathrm{Ci})$ for ${ }^{89} \mathrm{Sr}$ and $140 \mathrm{Ba}$, respectively. If fallout was directly ingested as a single intake of dust at 0.5 day post-detonation, then the intake of $140 \mathrm{Ba},{ }^{89} \mathrm{Sr}$, or ${ }^{131} \mathrm{I}$ would be in the same ratios as the activity per unit area for these nuclides given in Table 13. Thus, we roughly estimated the 
Table 19

Average Estinate of Inhaled Activity

\begin{tabular}{|c|c|c|c|c|c|c|c|c|c|}
\hline \multicolumn{10}{|c|}{ Ronge lap Island, uCia } \\
\hline Age & $\begin{array}{c}\text { Body } \\
\text { Weight, } \\
\text { kg }\end{array}$ & $\begin{array}{c}\text { Breathing } \\
\text { Rate } \\
\mathrm{cm}^{3} \min ^{-1}\end{array}$ & ${ }^{135} I$ & ${ }^{134} I$ & ${ }^{133} \mathrm{I}$ & ${ }^{132} I$ & ${ }^{131} I$ & ${ }^{132} \mathrm{Te}$ & $131 \mathbf{m}_{\mathrm{Te}}$ \\
\hline $\begin{array}{l}\text { Adult Male } \\
\text { Adult Female } \\
\text { Fourteen-Year-01d } \\
\text { Twelve-Year-01d } \\
\text { Yine-Year-01d } \\
\text { Six-Year-old } \\
\text { One-Year-Old } \\
\text { Newborn }\end{array}$ & $\begin{array}{l}70 \\
58 \\
50 \\
40 \\
30 \\
20 \\
10 \\
3.5\end{array}$ & $\begin{array}{r}20,000 \\
19,000 \\
19,000 \\
15,280 \\
11,530 \\
7,790 \\
4,050 \\
1,620\end{array}$ & $\begin{array}{l}24 \\
22 \\
22 \\
18 \\
14 \\
9.2 \\
4.8 \\
1.9\end{array}$ & $\begin{array}{l}10 \\
9.9 \\
9.9 \\
8.0 \\
6.0 \\
4.1 \\
2.1 \\
0.85\end{array}$ & $\begin{array}{l}11 \\
11 \\
11 \\
8.7 \\
6.6 \\
4.5 \\
2.3 \\
0.93\end{array}$ & $\begin{array}{l}2.6 \\
2.5 \\
2.5 \\
2.0 \\
1.5 \\
1.0 \\
0.53 \\
0.21\end{array}$ & $\begin{array}{l}0.48 \\
0.45 \\
0.45 \\
0.36 \\
0.27 \\
0.19 \\
0.096 \\
0.039\end{array}$ & $\begin{array}{l}2.9 \\
2.7 \\
2.7 \\
2.2 \\
1.7 \\
1.1 \\
0.58 \\
0.23\end{array}$ & $\begin{array}{l}0.55 \\
0.52 \\
0.52 \\
0.42 \\
0.32 \\
0.21 \\
0.11 \\
0.045\end{array}$ \\
\hline \multicolumn{10}{|c|}{ Sifo Is land, $\mu \mathrm{Ci}^{\mathrm{a}}$} \\
\hline $\begin{array}{l}\text { Adult Male } \\
\text { Adult Female } \\
\text { Fourteen-Year-0ld } \\
\text { Twelve-Year-0ld } \\
\text { Nine-Year-0ld } \\
\text { Six-Year-01d } \\
\text { One-Year-Old }\end{array}$ & $\begin{array}{l}70 \\
58 \\
50 \\
40 \\
30 \\
20 \\
10\end{array}$ & $\begin{array}{r}20,000 \\
19,000 \\
19,000 \\
15,280 \\
11,530 \\
7,790 \\
4,050\end{array}$ & $\begin{array}{l}2.2 \\
2.1 \\
2.1 \\
1.7 \\
1.3 \\
0.85 \\
0.44\end{array}$ & $\begin{array}{l}2.3 \\
2.2 \\
2.2 \\
1.8 \\
1.3 \\
0.90 \\
0.47\end{array}$ & $\begin{array}{l}2.3 \\
2.2 \\
2.2 \\
1.7 \\
1.3 \\
0.89 \\
0.46\end{array}$ & $\begin{array}{l}0.12 \\
0.11 \\
0.11 \\
0.090 \\
0.068 \\
0.046 \\
0.024\end{array}$ & $\begin{array}{l}0.023 \\
0.022 \\
0.022 \\
0.017 \\
0.013 \\
0.0089 \\
0.0046\end{array}$ & $\begin{array}{l}0.15 \\
0.14 \\
0.14 \\
0.11 \\
0.085 \\
0.058 \\
0.039\end{array}$ & $\begin{array}{l}0.029 \\
0.028 \\
0.028 \\
0.023 \\
0.017 \\
0.012 \\
0.0060\end{array}$ \\
\hline \multicolumn{10}{|c|}{ Utirik Island, ${ } \mathrm{Ci}^{\mathrm{a}}$} \\
\hline $\begin{array}{l}\text { Adult Male } \\
\text { Adult Fenale } \\
\text { Fourteen-Year-Old } \\
\text { Twe lve-Year-01d } \\
\text { Nine-Year-0ld } \\
\text { Six-Year-01d }\end{array}$ & $\begin{array}{l}70 \\
58 \\
50 \\
40 \\
30 \\
20\end{array}$ & $\begin{array}{l}7,500 \\
6,500 \\
6,500 \\
5,650 \\
4,250 \\
2,850\end{array}$ & $\begin{array}{l}1.9 \\
1.7 \\
1.7 \\
1.5 \\
1.1 \\
0.74\end{array}$ & $\begin{array}{l}0.00020 \\
0.00017 \\
0.00017 \\
0.00014 \\
0.00011 \\
0.000074\end{array}$ & $\begin{array}{l}33 \\
29 \\
29 \\
25 \\
19 \\
13\end{array}$ & $\begin{array}{l}11 \\
9.6 \\
9.6 \\
8.4 \\
6.3 \\
4.2\end{array}$ & $\begin{array}{l}2.1 \\
1.8 \\
1.8 \\
1.6 \\
1.2 \\
0.80\end{array}$ & $\begin{array}{l}11 \\
9.6 \\
9.6 \\
8.3 \\
6.3 \\
4.2\end{array}$ & $\begin{array}{l}1.7 \\
1.4 \\
1.4 \\
1.2 \\
0.94 \\
0.63\end{array}$ \\
\hline $\begin{array}{l}\text { One-Year }=01 d \\
\text { Newborn }\end{array}$ & $\begin{array}{l}10 \\
3.5\end{array}$ & $\begin{array}{r}1,450 \\
540\end{array}$ & $\begin{array}{l}0.37 \\
0.14\end{array}$ & $\begin{array}{l}0.000038 \\
0.000014\end{array}$ & $\begin{array}{l}6.4 \\
2.4\end{array}$ & $\begin{array}{l}2.2 \\
0.80\end{array}$ & $\begin{array}{l}0.41 \\
0.15\end{array}$ & $\begin{array}{l}2.1 \\
0.79\end{array}$ & $\begin{array}{l}0.32 \\
0.12\end{array}$ \\
\hline
\end{tabular}

apultiply by $3.7 \times 10^{4}$ to obtain Bq. 
Table 20

Total Radioiodine and Radiotellurium Activity Intake and Corresponding Age

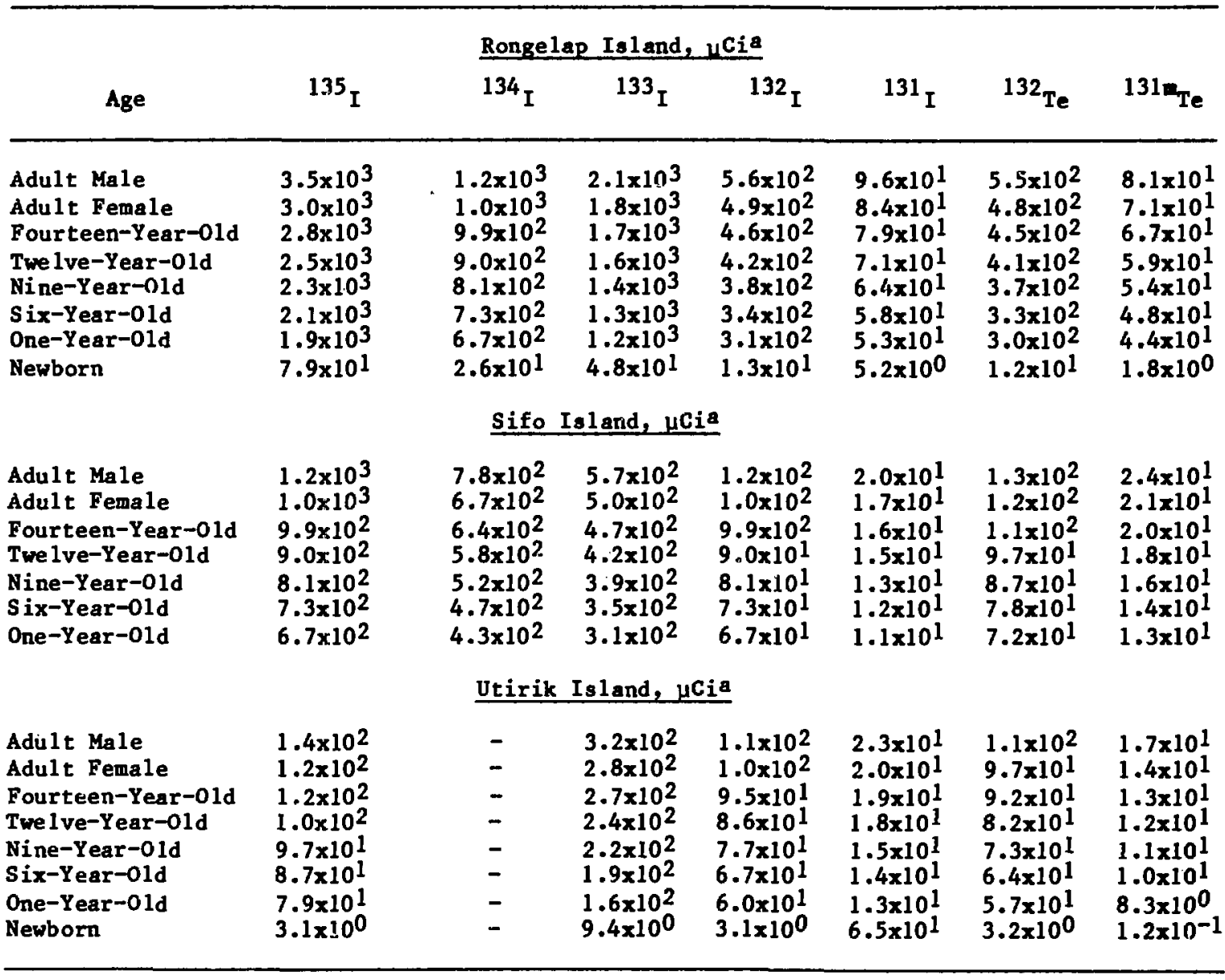

a Multiply by $3.7 \times 10^{4}$ to obtain Bq. 


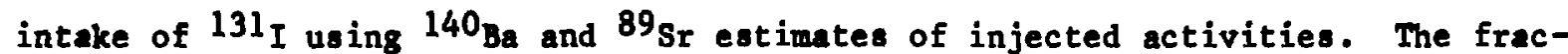
tions ingested and absorbed into body fluids were taken to be 1.0 for iodine, 0.2 for strontium and 0.06 for barium (ICRP68). We assumed instantaneous transfer from ingestion with meals up to the point of injection into systenic body fluids. The corresponding estimated intakes were $1.2 \times 10^{5} \mathrm{~Bq}(3.1 \mu \mathrm{Ci})$ for ${ }^{89} \mathrm{Sr}$ and $1.0 \times 10^{7} \mathrm{~Bq}(270 \mu \mathrm{Ci})$ for $140 \mathrm{Ba}$. If iodine, barium, and strontium were taken as dust, then we estimate 131 I intake as $2.4 \times 10^{6} \mathrm{~Bq}(64.1 \mu \mathrm{Ci})$ or $1.8 \times 10^{7} \mathrm{~Bq}(490 \mu \mathrm{Ci})$ based on strontium or barium intakes, respectively.

i. Absorption Through Skin.' According to Glasstone (G162), fa11out will enter the body through the digestive tract, through the lungs, or through wounds or abrasions. No direct absorption through skin is reported in JCAR57, JCCRRER56, G162, Cr56, or Du56. Beta burns appeared on the skin of Rongelap people many weeks after exposure; thus at the time of contamination we believe skin was intact. Harrison (Ha63) measured the extent to which gaseous ${ }^{131} \mathrm{I}_{2}$ and aqueous solutions of $\mathrm{K}^{131} \mathrm{I}$ and ${ }^{131} \mathrm{I}_{2}$ were absorbed through human skin. For aqueous $\mathrm{K}^{13}{ }^{1} \mathrm{I}$, the mean absorption rate was $7.8 \times 10^{-4} \mathrm{~h}^{-1}$ and for ${ }^{131} \mathrm{I}_{2}$ it was less. Use of stable I carrier with the gas was found to irritate and blister skin which may have led to the increased absorption reported for gaseous ${ }^{13} \mathrm{I}_{2}$ (Ha63). We asgumed $0.17 \mathrm{~m}^{2}$ of skin surface was exposed, a skin surface activity of $110 \mathrm{MBq} \mathrm{m} \mathrm{m}^{-2}\left(3.1 \times 10^{3} \mu \mathrm{Ci} \mathrm{m^{-2 }}\right)$, and 49 hours of exposure at Rongelap Island. These assumptions led to an upper estiunated intake of $0.7 \mathrm{MBq}(19 \mu \mathrm{Ci})$ 131 I based on an absorption rate of $7.8 \times 10^{-4} h^{-1}$. This was an upper estimate since the skin surface was likely to be less contaminated than the ground surface because of swimming and bathing. Assuming that the urine bioassay results of Harris (Ha54) were accurate, we estimate the intake through skin to be as much as $20 \%$ of the total intake for $131_{I}$. It was not likely that skin was as contaminated as the ground and, therefore, we do not consider this to be an inportant pathway.

\section{Absorbed Dose for Individuals}

a. Absorbed Eose per Unit Activity Intake. Radioiodine and radiotellurium thyroid absorbed-dose commitment per unit activity intake and corresponding age were compiled in Table 21 from dose equivalent per unit intake results generated by Johnson (Jo81, Jo82). We performed an exponential interpolation of pre-adult values in order to generate all the results given here. Thyroid absorbed-dose commitment was generated because all the nuclides of interest to us had half-lives much shorter than 50 years, the integration interval used by Johnson to generate committed dose equivalents. The values for the tellurium isotopes were generated from reference man data in Limits for Intakes of Radionuclides by Workers (ICRP79). The tellurium isotope values listed in Table 21 for the pre-adult ages were generated by ratios of the Johnson values for the appropriate iodine daughters. The thyroid absorbed dose for a person of any age per unit activity intake for tellurium was assumed to be directly proporticnal to the product of the adult value and the ratio of the iodine value. For example, 132 Te rad per $\mu$ Ci for a six-year-old (see Table 21 ) would be the product of 0.22 (taken from the ${ }^{132} \mathrm{Te}$ column of Table 21) and the ratio of 0.048 to 0.013 (taken from the ${ }^{132}$ I column of Table 21 ). 
Table 21

Radioiodine and Radiotellurium Thyroid Absorbed-Dose Commitment per Unit Activity Intake and Corresponding Age

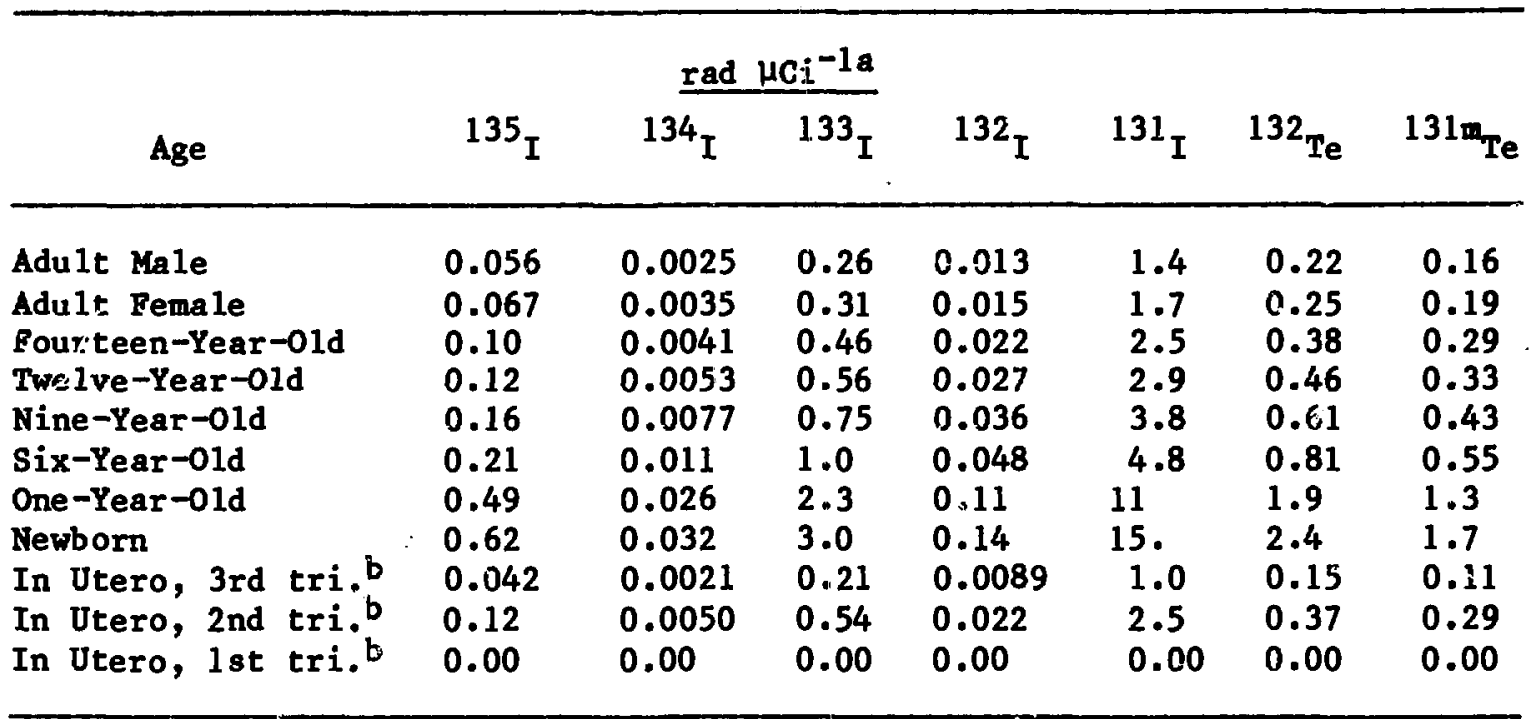

aultiply by $2.7 \times 10^{-7}$ to obtain $\mathrm{Gy} \mathrm{Bq}^{-1}$.

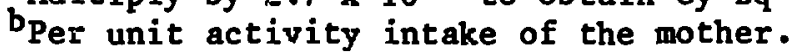

b. Thyroid Absorbed Dose. We compiled the product of age-specific intake (see Table 20) and age-specific thyroid absorbed dose per unit intake (see Table 21) for several specific ages (Table 22). The thyroid absorbed dose from all iodine and tellurium nuclides was 7.7 times the dose due to 131 I at Rongelap Island for an adult male. It was 10 times the dose due to ${ }^{131}$ I at Sifo Island and 4.7 times the dose due to 131 I at Utirjik Island.

The most probable ingestion dose evaluation by James (Ja64) for a 3.5-year-old Rongelap girl was given as 14.45 gray (1445 rad). James chose this age because three teenage females were the first to develop thyroid nodules, 10 years after the acute exposure. James assumed the total thyroid absorbed dose from ingestion of all iodine isotopes in fallout was 2.6 times the thyroid dose due to ${ }^{131} \mathrm{I}$. This factor of 2.6 is dependent upon the age of the fallout and the age of the individual and differs considerably from our estinates. Since James based the total thyroid dose on ${ }^{131} I$ measurements in urine and this factor of 2.6, there is a significant difference in thyroid dose derived by our method and that derived by James. Adjusting the James ingestion dose estimate by multiplying by the ratio of 8.6 (our factor for a 3.5 -year-old person) to 2.6 increases the total thyrcid absorbed dose estimate of James to 47.8 gray (4780 rad). The comparable result for a 3.5-year-old, using our method and Johrson's (Jo81) dose conversion factor, was 37 gray (3700 rad). 
Table 22

Eatinated Radioiodine and Radiotellurium Thyroid Absorbed Dose and Corresponding Age

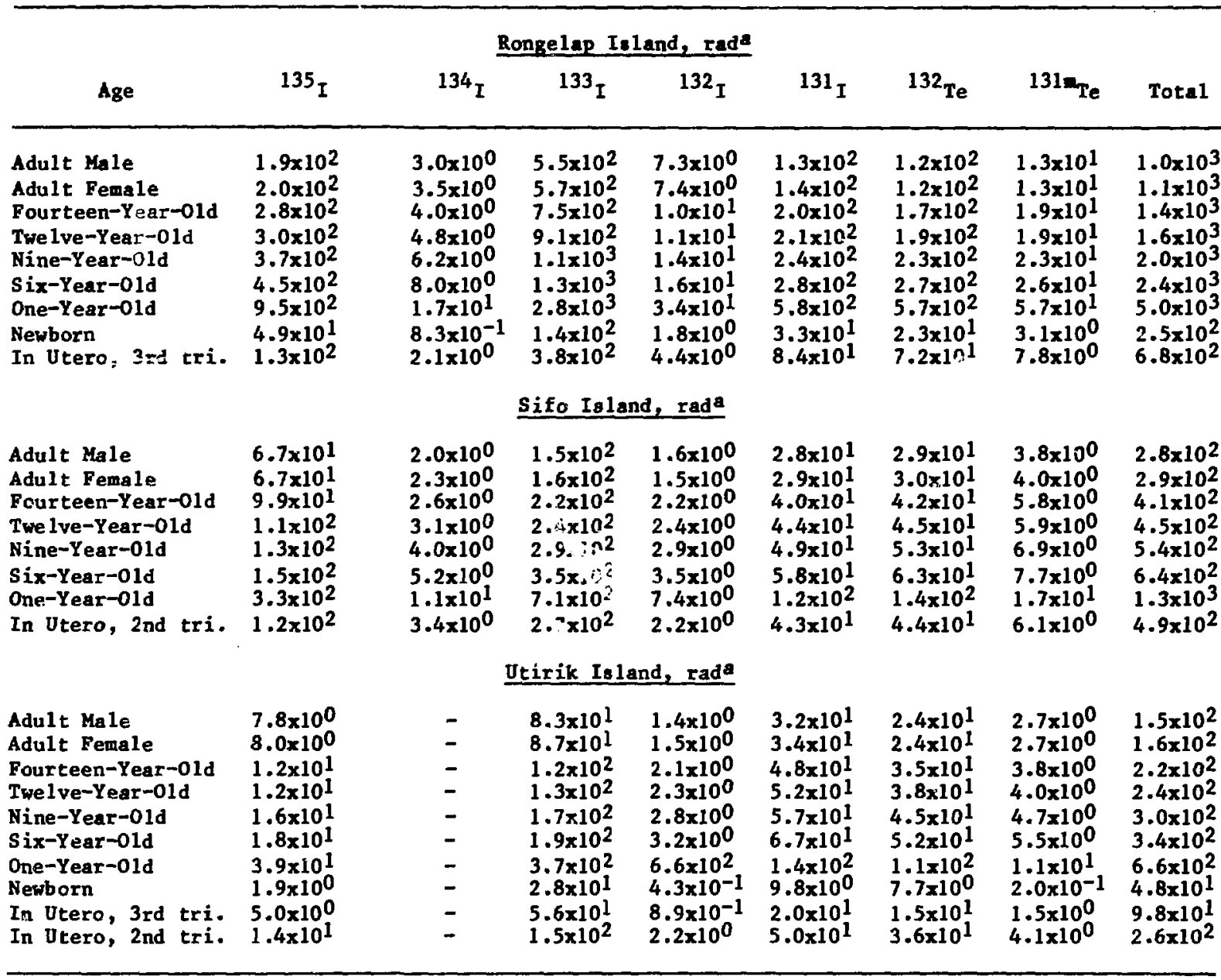

aMultiply by 0.01 to obtain Gy. 
The contribution from the decay of each radioiodine nuclide to thy roid absorbed dose was dependent upon the time post-detonation and upon the fractionation of the isobaric chains giving rise to the radioiodines. Both factors influenced our estimate of thyroid absorbed dose. Janes assumed theoretical fission yields and that one third the ingestion intake occurred at ten hours and two thirds at 30 hours post-detonation. We assumed Bikini ash fractionation

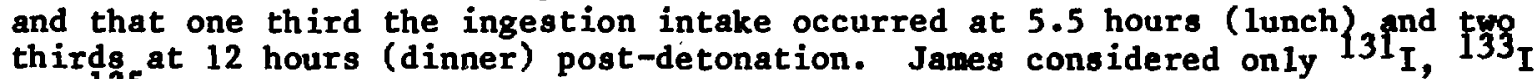
and $135 \mathrm{I}$ in the thyroid-dose estimate. We considered all likely iodine and tellurium nuclides. Additionally, James adjusted the thyroid dose downward to $10.5 \mathrm{gray}$ (1050 rad) for a 3.5-year-old to account for tiue possibility that part of the intake was due to inhalation. We considered inhalation intake to be insignificant relative to ingestion intake and compared the James ingestion estimate to our ingestion estimate.

c. Maximum Thyroid Absorbed Dose. He used several wethods to estiante a range of fallout material ingested. One was to ingest known quantities of pharmaceutical-grade $\mathrm{CaCO}_{3}$ with meals and subjectively arrive at descriptions of taste similar to those given by the Rongelap people at the time of evacuation in March 1954. A group of five adult white males at BNL reported that 200 mg of $\mathrm{CaCO}_{3}$ could not be sensed by taste when mixed with food. Another method was to assume that the range of weights associated with the contents of the stomach in cases of sudden death corresponded to the range of activity intake (Ev66). This range - 0 to $380 \mathrm{~g}$, mean $82 \mathrm{~g}$ - implies a maximum intake of about 5 times the mean value. Another method was to examine the range of $137 \mathrm{Cs}$ daily activity intake estimated from 1957 to 1983 for Rongelap and Utirik people (Le84). The intake rate was estimated from whole-body counting results. The range of $137 \mathrm{Cs}$ intake rate yas about 5 times the mean value. Another method was to examine the range of 137 Cs body burden exhibited by the population inhabiting Bikini Island from 1974 to 1978 (Mi83). The I inge was about 3.2 times the mean value. From the above range values, we assumed $a$ value of 4 times the intake and thus 4 times the mean thyroid absorbed dose for estimates made here (see Table 23).

\section{d. External Sources of Thyroid Dose. External thyroid absorbed dose} estimates were based on integrated photon exposure given previously and on an adjustment for living pattern in a variable exposure-rate environment. Further detail about the adjustment can be found in (Na80) and (Le84).

Some questions about the external beta radiation penetrating to the depth of the thyroid were expressed by Cronkite (Cr81). The thickness of tissue overlying the thyroid ranges from 0.4 to $2.0 \mathrm{~cm}$, average $0.82 \mathrm{~cm}$, and does not correlate well with age or body weight (ICRP74). A minimum beta energy of $1.8 \mathrm{MeV}$ was estimated by us for penetration of $0.82 \mathrm{~cm}$ of tissue. At Rongelap Island, about $70 \%$ of the population had skin lesions on some part of the neck. The lesions appeared initially about 21 days post-exposure (Cr56). This would imply a skin surface dose of tens of gray (several thousand rad). Only a small percent of the beta flux was above $1.8 \mathrm{MeV}$ in kinetic energy. of this higher energy flux, only a small. fraction would penetrate $0.82 \mathrm{~cm}$ of tissue and deposit energy in the thyroid. Thus, we considered thyroid dose from this pathway to be insignificant. 
Table 23

Total Thyroid Absorbed-Dose Estimate

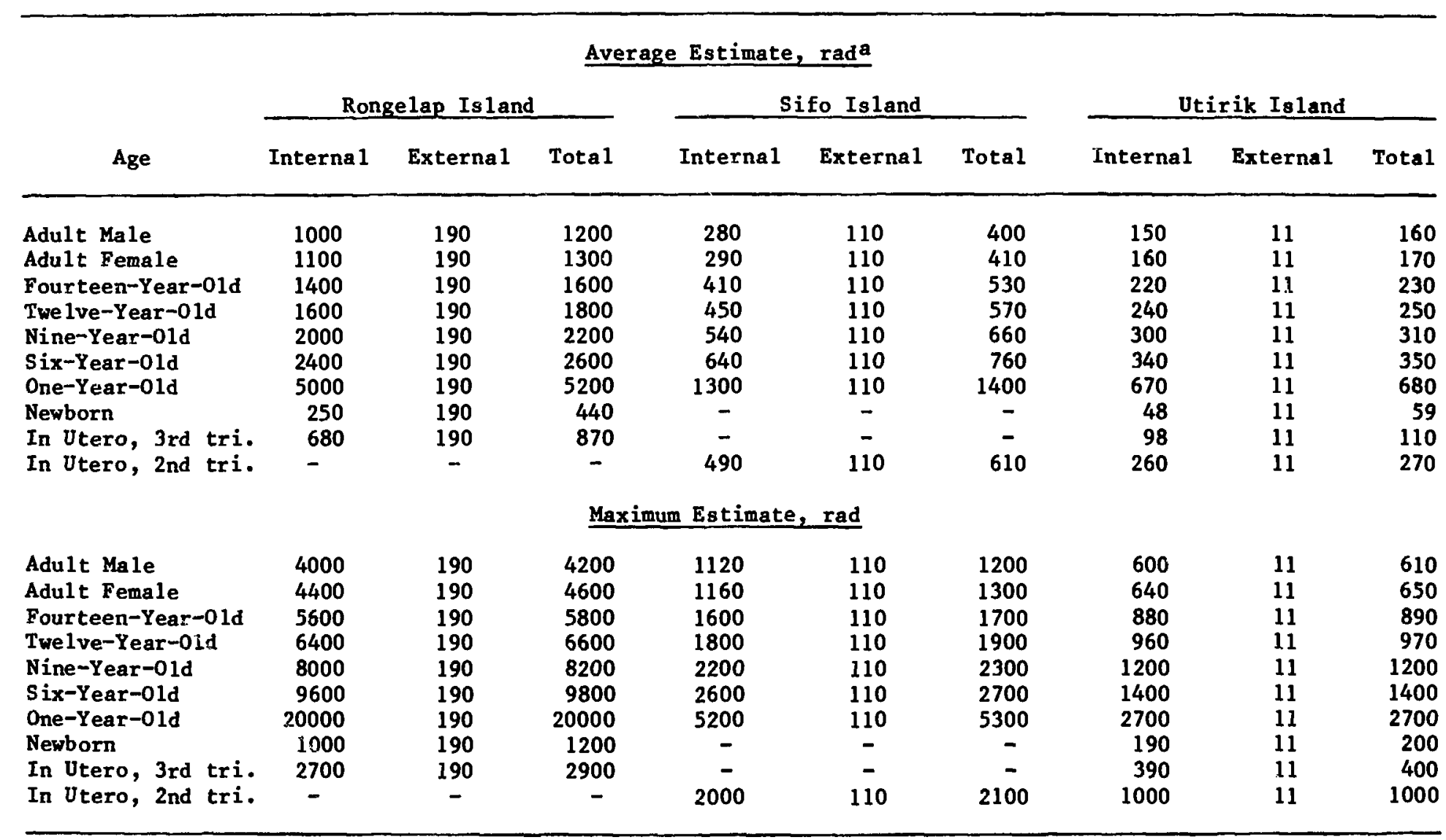

aMultiply by 0.01 to obtain Gy. 


\section{THYROID WODULES AND TMYROID CANCER RISK FROM FALLOUT}

\section{A. Tabulation of Thyroid Effects and Age at Exposure}

Medical records were reviewed by Adams of the Marshall Islands Medical Program for age at exposure and thyroid nodule data. Conard had performed a sinilar tabulation $(\mathrm{Co80})$. Memoranda between the evacuation teans and their superiors were reviewed for age-at-exposure data (0c68). Data gathered by the Marshall Islands Radiological Safety Program related to age at the time of whole-body counting measurements were reviewed. When discrepancies between the three sources of age data became apparent (about April 1982) Medical Program records were assumed correct. Differences, between age groupings reported in Table 1 of the Conard report (Co80) and Tables 24 or 25 as reported here, exist because of the age-at-exposure discrepancies.

Two young Rongelap males with severe growth retardation and gradual1y developed atrophy of the thyroid gland were not included in Tables 24 and 25 because thyroid nodules would not develop in these individuals. Surgical exanination of nodules detected by palpation in the field revealed four persons without nodules at the time of surgery (see Table 24). In addition, two persons too old to undergo surgery were included among those having nodules.

B. Tabulation of Risk of Thyroid Cancer

The unexposed population incidence rate of thyroid cancer was higher at Rongelap and Utirik than for other sea-level populations, 2 cancers per hundredthousand person-years observed at singapore (Le82) versus 59 cancers per hundredthousand person-years observed in the Marshall Islands couparison group. The comparison group makeup has been described previously by Conard (Co80). Thyroidcancer in the United States has been diagnosed at the rate of 2.5 per hundredthousand person-years observed (De75).

Our estinated value for thyroid cancer risk from fallout for the exposed population is 150 cancers per million person-gray-years at riak ( 1.5 cancers per million person-rad-years). This estimate was based on the Marshall Islands' conparison group incidence, thyroid doses estimated here, and thyroid observations in the exposed groups at Rongelap, Utirik, and Sifo Islands (see Table 25). It could be assumed that the larger studies of cancer gave a more accurate reflection of the spontaneous incidence rate of thyroid cancer at Rongelap and Utirik than the comparison group statistics. For a population of 251 people examined over 29 years, about 0.15 thyroid cancers would be expected on the basis of the rate given at Singapore (Le82). This value when incorporated into the estinate of cancer risk from radiation exposuxe leads to a Rongelap-Utirik-Sifo population value of 210 thyroid cancers per million person-gray-years at risk (2.1 thyroid cancers per million person-rad-years at risk), $40 \%$ higher than the value we estimated using Marshallese comparison statistics.

\section{Comparison to Other Estimates of Thyroid Cancer Risk}

The value for the radiation-induced incidence of thyroid cancer was 147 per million person-gray-years ( 1.47 cancers per million person-rad-years) for 
Table 24

Tabulation of Thyroid Results

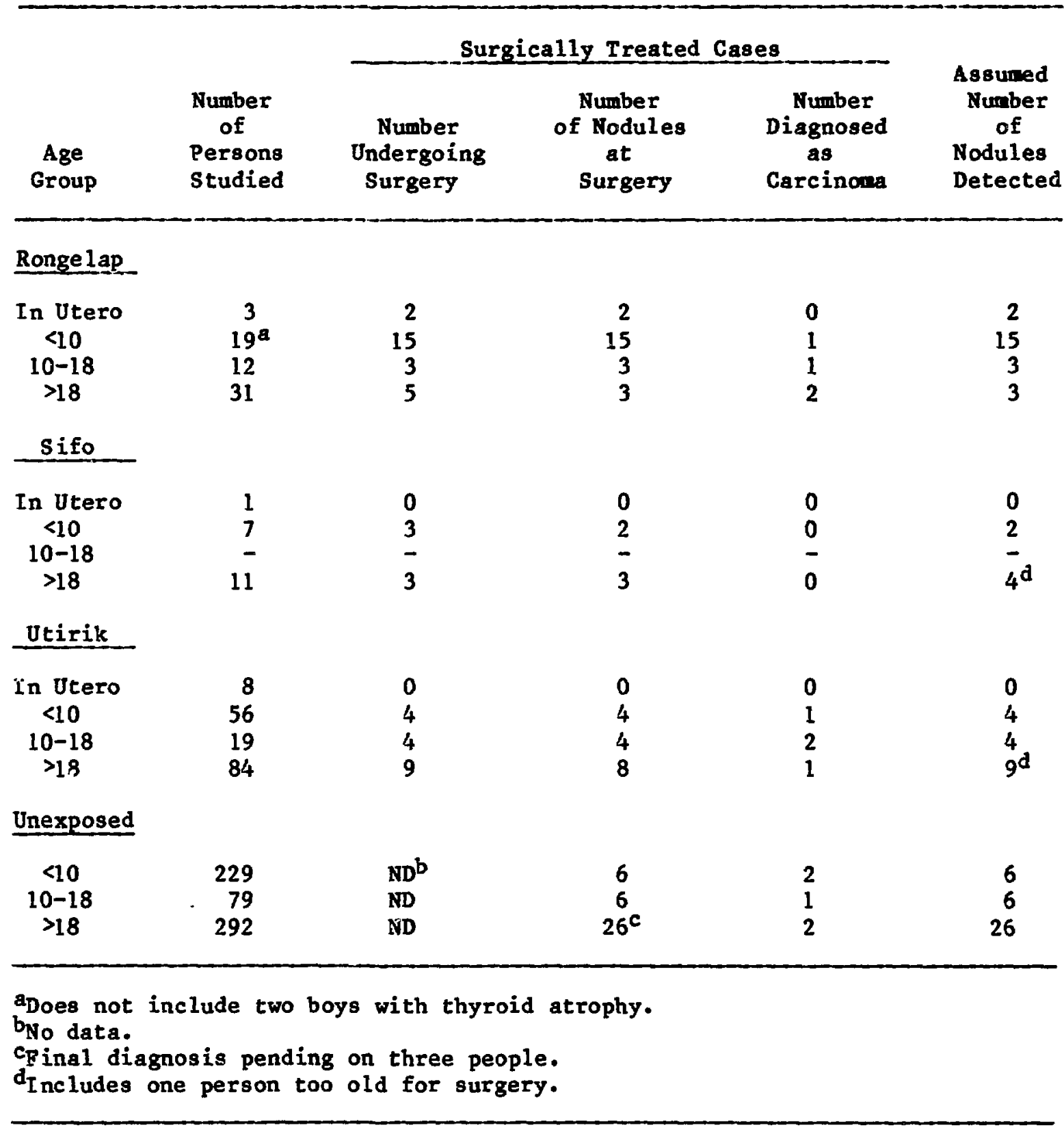


Table 25

Summary of Thyroid Results

\begin{tabular}{|c|c|c|c|c|c|c|c|c|c|}
\hline $\begin{array}{c}\text { Age at } \\
\text { Exposure }\end{array}$ & $\begin{array}{l}\text { Tota1 } \\
\text { Number }\end{array}$ & Nodulesa & $\begin{array}{l}\text { No. with } \\
\text { Carcinoma }\end{array}$ & $\begin{array}{c}\text { Expected } \\
\text { Nodules } b, c\end{array}$ & $\begin{array}{c}\text { Expected } \\
\text { Cancers } b, c\end{array}$ & $\begin{array}{l}\text { Mean } \\
\text { Adsorbed } \\
\text { Dose, } \\
\text { rads }\end{array}$ & $\begin{array}{c}\text { Mean } \\
\text { Module Time } \\
\text { at Risk } \\
\text { (Cancer), } \\
\text { years }\end{array}$ & $\begin{array}{l}\text { Mean Nodule } \\
\text { Risk, No. } \\
\text { per } 10^{6} \\
\text { person-rad- } \\
\text { yearsd }\end{array}$ & $\begin{array}{l}\text { Mean Cancer } \\
\text { Riak, No. } \\
\text { per } 10^{6} \\
\text { person-rad- } \\
\text { yearsd }\end{array}$ \\
\hline \multicolumn{10}{|l|}{ Rongelap } \\
\hline $\begin{array}{c}\text { In Jtero } \\
<10\end{array}$ & $\begin{array}{c}3 \\
19 \mathrm{e}\end{array}$ & $\begin{array}{r}2 \\
15\end{array}$ & $\begin{array}{l}0 \\
1\end{array}$ & $\begin{array}{l}0.079 \\
0.50\end{array}$ & $\begin{array}{l}0.026 \\
0.17\end{array}$ & $\begin{array}{r}640 \\
4000\end{array}$ & $\begin{array}{l}23(-) \\
13(15)\end{array}$ & $\begin{array}{l}43 \\
15\end{array}$ & $\overline{0.73}$ \\
\hline $\begin{array}{l}10-18 \\
>18\end{array}$ & $\begin{array}{l}12 \\
31\end{array}$ & $\begin{array}{l}3 \\
3\end{array}$ & $\begin{array}{l}1 \\
2\end{array}$ & $\begin{array}{l}0.92 \\
2.7\end{array}$ & $\begin{array}{l}0.15 \\
0.21\end{array}$ & $\begin{array}{l}1700 \\
1300\end{array}$ & $\begin{array}{l}17(22) \\
17(13)\end{array}$ & $\begin{array}{l}6.0 \\
0.44\end{array}$ & $\begin{array}{l}1.9 \\
3.4\end{array}$ \\
\hline A11 Ages & 65 & 23 & 4 & 4.2 & 0.56 & 2100 & $15(16)$ & 9.2 & 1.6 \\
\hline \multicolumn{10}{|l|}{ Sifo } \\
\hline In Uterc & 1 & 0 & 0 & 0.026 & 0.0087 & 610 & $-(-)$ & - & - \\
\hline$<10$ & 7 & 2 & 0 & 0.18 & 0.061 & 1100 & $22(-)$ & 11 & - \\
\hline $10-18$ & - & - & - & - & - & - & $-(-)$ & - & - \\
\hline$>18$ & 11 & 4 & 0 & 0.98 & 0.075 & 410 & $18(-)$ & 37 & - \\
\hline A11 Age8 & 19 & 6 & 0 & 1.2 & 0.15 & 670 & $19(-)$ & 20 & - \\
\hline \multicolumn{10}{|l|}{ Utirik } \\
\hline In Utero & 8 & 0 & 0 & 0.21 & 0.070 & 130 & $-(-)$ & - & - \\
\hline$<10$ & 56 & 4 & 1 & 1.5 & 0.49 & 490 & $25(21)$ & 3.6 & 0.89 \\
\hline $10-18$ & 19 & 4 & 2 & 1.4 & 0.24 & 220 & $22(22)$ & 27 & 19. \\
\hline$>18$ & 84 & 9 & $\overline{1}$ & 7.5 & 0.58 & 170 & $22(22)$ & 4.8 & 1.3 \\
\hline Al1 Ages & 167 & 17 & 4 & 11 & 1.4 & 280 & $23(22)$ & 5.9 & 2.5 \\
\hline \multicolumn{10}{|l|}{ Al1 Exposed } \\
\hline In Utero & 12 & 2 & 0 & 0.32 & 0.10 & 290 & $23(-)$ & 21 & - \\
\hline$<10$ & 82 & 21 & 2 & 2.2 & 0.72 & 1400 & $16(18)$ & 10 & 0.65 \\
\hline $10-18$ & 31 & 7 & 3 & 2.3 & 0.39 & 790 & $20(22)$ & 9.6 & 5.1 \\
\hline$>18$ & 126 & 16 & 3 & 11 & 0.87 & 470 & $20(16)$ & 4.4 & 2.2 \\
\hline Al1 Ages & 251 & 46 & 8 & 16 & 2.1 & 800 & $18(19)$ & 8.3 & 1.5 \\
\hline
\end{tabular}

Includes sone cases not surgically treated.

bised on prevalence in unexposed Marshallese.

cIn utero values based on age leas than teri prevalence.

dYultiply by 100 to obtain number per $10^{6}$ person-gray-years.

eDoes not include two boys with thyroid atrophy. 
Nagasaki persons who received greater than 50 rad (CBEIR80). A value of 220 per million person-gray-years ( 2.2 cancers per million person-rad-years) was reported for individuals exposed at Hiroshima (CBEIR80). A group of 2611 people who were irradiated during the first year of life for presumed enlargement of the thymus gland exhibited an incidence of 290 per million person-gray-years (2.9 cancers per million person-rad-years) (CBEIR8C). The University of Chisago head and neck irradiation sample of 100 children irradiated at about 4.5 years of age resulted in a risk of thyroid cancer of about 400 per million persongray-years (4 cancars per million person-rad-years) (CBEIRB0). The Michael Reese Hospital head and neck irradiation sample of 2109 people irradiated during infancy, childhood, or adolescence exhibited a thyroid cancer risk of 210 per million person-gray-years ( 2.1 cancers per million person-rad-years) (CBIER80). A person-weighted average of the above values gives a combined risk of about 200 per million person-gray-years ( 2 thyroid cancers per million person-rad-years). Thus, the comparison of risk from Marshall Islands fallout studies to external irradiation studies involving instantaneous doses to the thyroid showed no $\mathrm{ag}$ nificant difference.

Scalp irradiation of over 10,000 Jewish children resulted in an absolute risk estimate of 630 per million person-gray-years (6.3 thyroid cancers per million person-rad-years) (CBEIR80). Another study of $261 \mathrm{Jewish}$ persons irradiated during infancy for presumed enlargement of the thymus resulted in a risk of 480 per million person-gray-years ( 4.8 thyroid cancers per million person-rad-years) (CBEIR80). Comparison of our value to Jewish populations showed no statistically significant difference due to variations in doses estimated in either of the exposed groups (Ha52).

Studies of children exposed to fallout radioiodine in Utah and Nevada have not revealed any excess thyroid cancers (CBEIR80). There is no evidence to demonstrate a carcinogenic effect in $p$ sple following intake of 131 I for treatment of hyperthyroidism (CBEIR80). No velue of risk can be estimated for ${ }^{131_{I}}$ exposure on the basis of Marshall Islands experience. This is because the internal dose to the Marshallese thyroids from ${ }^{13}$ I amounted to about 10 to $20 \%$ of the total thyroid dose. The beta to gamma dose ratio from the BRAVo mixture of iodines plus external radiation was not similar to ${ }^{13} 1_{I}, 3.5$ versus 7.5 respectively. Another major difference between ${ }^{13} 1_{I}$ exposure and the Marshallese exposure was dose rate.

D. Estimate of the Uncertainty in the Derived-Risk Estimate

In order to estimate the uncertainty in the derived risk estimate the following argument was used.

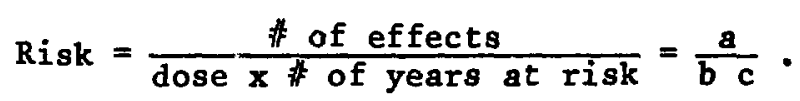

The uncertainty in the risk, $\Delta$ Risk, is approximately the sum of the products of the uncertainties in $a, b$ or $c$ times the effect that $a, b$ or $c$ have on the value of risk (Be69). 


$$
\Delta \text { Risk }=\Delta a\left(\frac{\partial \text { Risk }}{\partial a}\right)+\Delta b\left(\frac{\partial \text { Risk }}{\partial b}\right)+\Delta c\left(\frac{\partial \text { Risk }}{\partial c}\right) .
$$

The terms in parenthesis are the partial derivatives of risk with respect to a, $b$ or $c$. We assumed the partial derivatives were constant over the ranges of a, b and c. For our purposes Eq. 2 reduces to

$$
\frac{\Delta \text { Risk }}{\text { Risk }}=\frac{\Delta a}{a}+\frac{\Delta b}{b}+\frac{\Delta c}{c} .
$$

We do not know the actual uncertainty $\Delta a, \Delta b$ or $\Delta c$, however, we know the standard deviation, $\sigma$, which is characteristic of the probable uncertainty. Bevington (Be69) develops the use of standard deviation to estimate the uncertainty with the result that for our application

$$
\sigma_{\text {Risk }}{ }^{2}=\sigma_{a}{ }^{2}\left(\frac{\partial \text { Risk }}{\partial a}\right)^{2}+\sigma_{b}{ }^{2}\left(\frac{\partial \text { Risk }}{\partial b}\right)^{2}+\sigma_{c}{ }^{2}\left(\frac{\partial \text { Risk }}{\partial c}\right)^{2}
$$

Here we have assumed the fluctuations in $a, b$ and $c$ are uncorrelated. Applying Eq. 4 to Eq. 1 yields

$$
\frac{\sigma_{\text {Risk }}{ }^{2}}{\text { Risk }^{2}}=\frac{\sigma_{a}^{2}}{a^{2}}+\frac{\sigma_{b}{ }^{2}}{b^{2}}+\frac{\sigma_{c}{ }^{2}}{c^{2}}
$$

The standard deviation in the number of effects, $\sigma_{a}$, was assumed to be equal to the square root of the number of excess nodules, that is, $\sigma_{a}=5.5$ and $a=30$. Thus the relative standard deviation equals 0.18 (i.e. $\sigma_{a} / a=0.18$ ). This is in fair agreement with the fact that out of 48 persons undergoing surgery for nodules only 44 had nodules. In the reverse sense nodules could have gone undetected.

The standard deviation in the number of years at risk, $\sigma_{c}$, was taken as equal to the standard deviation associated with the mean years at risk, which we reported in Table 25. Thus, $\sigma_{c}$ equals 5.5 years and $\sigma_{c} / c$ equals 0.30 .

The standard deviation in absorbed dose to the thyroid, $\sigma_{b}$, was estimated from the standard deviations associated with 1) the urine result, 2) the $131_{\text {I }}$ intake estimate, 3) the absorbed dose from ${ }^{131_{I}}$ and 4) the ratio of ${ }^{131_{I}}$ dose to total thyroid dose. Each of these was assigned a relative standard deviation equal to 0.7 .

The assigned value of 0.7 for each of the relative standard devigtions of 1 through 4 above was based on the following. The observed value for ${ }^{90} \mathrm{Sr}$ urine activity was nearly 0.7 (Le84). This uncertainty in urine activity excreted is largely from two sources, the measurement technique and the day-to-day metabolism changes in adults. It was assumed that the relative standard deviation associated with ${ }^{90} \mathrm{Sr}$ activity in urine applied to ${ }^{13} 1_{\mathrm{I}}$ activity in urine as well. The uncertainty associated with transforming a urine result into an intake estimate comes from uncertainty in the true excretion function for iodine in adults and from not knowing the true time of intake. Assigning a relative standard deviation of 0.7 was thought to be conservative. The uncertainty 
associated with absorbed dose in the thyroid per unit intake of ${ }^{131}$ I was reported by Dunning (Du81). The uncertainty associated with the ratio of ${ }^{131_{1}}$ I dose to total thyroid dose comes frow not knowing the true composition of the BRAVO fallout (see Ja64, Ph82) and from not knowing the true time of intake. We assigned the value of 0.7 for the relative standard deviation of this quantity.

Since total dose was related to 1 through 4 above by either multiplication or division, the relative standard deviation for absorbed dose was taken as

$$
\frac{\sigma_{b}}{b}=\sqrt{(0.7)^{2}+(0.7)^{2}+(0.7)^{2}+(0.7)^{2}}=1.4 \text {. }
$$

The relative standard deviation was estimated for risk based on the above values for $\sigma_{a} / a, \sigma_{b} / b$ and $\sigma_{c} / c$. Thyroid absorbed dose, number of years at risk, and number of effects are related to risk by multiplication and division. The relative standard deviation in risk was calculated in a similar way as was done for absorbed dose. We estimate the mean and standard deviation of thyroid cancers per million person-gray-years at risk to be equal to $150 \pm 230(1.5 \pm 2.3$ cancers per million person-rad-years at risk). Our estimate of the nodule risk rate and standard deviation was $830 \pm 1200$ nodules per million person-gray-years at risk ( $8.3 \pm 12$ nodules per million person-rad-years at risk). 


\section{REPERENCES}

Bal0 Bateman, H., 1910, "The Solution of a System of Differential Equations Occurring in the Theory of Radioactive Transformations," Proceedings of the Cambridge Philosophical Society, $15,423$.

Be67 Berman, M., 1967, "The Iodine Poo1," in: Compartwents Pools and Spaces in Medical Physiology, U.S. Atomic Energy Comission Report, Symposium Series II, Washington, D.C.

Be69 Bevington, P.R., 1969, Data Reduction and Error Analysis for the Physical Sciences, McGraw-Hil1 Book Company, New York.

Be80 Beck, H. L., 1980, Exposure Rate Conversion Factors for Radionuclides Deposited on the Ground, Environmental Measurements Laboxatory Report, New York, EML-378.

Bo56 Borg, D.C., 1956, "Theoretical Calculations of the Gamma Radiation Spectrum from Initial and Fallout Radiations of Nuclear Weapons," in: The Shorter-Term Biological Hazards of a Fallout Field, U.S. Atomic Energy Comission Report, Washington, D.C.

Br74 Brauer, F.P. Soldat, J.D., Tenny, H., and Strebin, R.S., 1974, "Natura1 Iodine and Iodine-129 in Mammalian Thyroids and Environmental Samples Taken From Locations in the United States," in: Environmental Surveillance Around Nuclear Installations II, International Atomic Energy Agency Report, IAEA-SM-180/34, Vienna.

Br80 Brauer, F.P. and Naidu, J., 1980, 129 I Analys is of Marshal1 Islands Environmenta I Samples, Analytical and Quality Assurance Procedures, Progress Report, Brookhaven National Laboratory, Upton, NY.

CBEIR80 Committee on the Biological Effects of Ionizing Radiation, 1980, The Effects on Populations of Exposure to Low Leve 1s of Ionizing Radiation: 1980, National Research Council Report, National Academy Press, Washington, D.C.

Co72 Cole, R., 1972, Inhalation of Radioiodine from Fallout: Hazards and Countermeasures, Environmental Science Associates Report, Burlingame, CA, ESA-TR-72-01.

Co74 Conard, R.A.. et a1., 1974, A Twenty Year Review of Medical Findings in a Marshallese Population Accidenta1ly Exposed to Radioactive Fallout, Brookhaven National Laboratory, Upton, NY, BNL 50424.

Co80 Conard, R.A. et al., 1980, Review of Medical Findings in a Marshallese Population Twenty Six Years After Accidental Exposure to Radioactive Fallout, Brookhaven National Laboratory, Upton, NY, BNL 51261 . 
Cr56 Cronkite, E.P., Bond, V.P., and Dunham, C.L., 1956, "A Report on the Marshallese and Americans Accidentally Exposed to Radiation from Pa11out and a Discussion of Radiation Injury in the Human Being," in: Some Effects of Ionizing Radiation on Human Beings, U.S. Atomic Energy Cormission, Washington, DC, USAEC-TID 5358.

Gr63 Grocker, G.R., 1963, Estimates of Pission Product Yields of a Thermonuclear Explosion, United States Naval Radiological Defense Laboratory Report, San Francisco, CA, USNRDL-TR-642.

Cr65 Crocker, G. R. and Turner, T., 1965, Galculated Activities, Exposure Rates, and Gamma Spectra for Unfractionated Fission Products, United States Naval Radiologica1 Defense Laboratory Report, San Francisco, CA, USNRDL-TR-1009.

Cr81 Cronkite, E., 1981, Letter to Charles Sondhaus, University of California, Irvine, CA.

De75 De Groot, L.J., 1975, "Thyroid Carcinoma," Med. C1in. N.A., 59, 1233.

Du56 Dunning, G.M. and Hilcken, J.A. (eds.), 1956, The Shorter-Term Biological Hazards of a Fallout Field, Symposium, 12-14 December, U.S. Atomic Energy Commission and Department of Defense, Washington, DC.

Du81 Dunning, D.E., Jr. and Schwarz, G., 1981, "Variability of Human Thyroid Characteristics and Estimates of Dose from Ingested ${ }^{131} \mathrm{I}$," Hea 1th Phys. 40, 661-675.

Ev66 Eve, I. S., 1966, "A Review of the Physiology of the Gastrointestina1 Tract in Relation to Radiation Doses from Radioactive Materials," Hea1th Phys. i2, 131-161.

Fr61 Freiling, E. C., 1961, "Radionuclide Fractionation in Bomb Debris," Science 133, 1991-1998.

G162 Glasstone, S. (ed.), 1962, The Effects of Nuclear Weapons, Defense Atomic Support Agency, Department of Defense, U.S. Atomic Energy Commission, Washington, DC.

Ha52 Hald, A., 1952, Statistical Theory with Engineering Applications, Wiley Publications, New York.

Ha54 Harris, P.S., 1954, A Summary of the Results of Urine Analyses on Ronge lap Natives, Americans and Japanese Fisherman to Date, Los Alamos Scientific Laboratory, Internal Memorandum, Los Alamos, NM.

Ha63 Harrison, J., 1963, "The Fate of Radioiodine Applied to Human Skin," Hea1th Phys. 9, 993-1000. 
Ha79 Hawthorne, H.A., Editor, 1979, Compilation of Local Pallout Data frow Test Detonations 1945-1962 Extracted Eron DASA 1251, Detende huclest Agency Report, DKA 1251-2-Ex, Santa Barbara, CA.

He65 Held, E., 1965, Gama Dose at Rongelap Ato11, 1954-1963, Laboratory of Radiation Biology, University of Washington, Seattle, KA, UWLO91 .

Hi81 Hicks, H.G., 1981, Results of Calculations of External Gama-Radiation Exposure Rates froin Fallout and the Related Radionuclide Compositions, Lawrence Liverwore Hational Laboratory Report, Livermore, CA, UCRL-53152.

Ho63 Holland, J. Z., 1963, "Distribution and Physical-Chenical Nature of Fallout," Feder. Proc. 22, 1390-1397.

ICRP68 International Comission on Radiological Protection, 1968, Report of Committee IV on Evaluation of Radiation Doses to Body Tissues from Interna 1 Contamination Due to Occupscional Exposure, ICRP Publication 10 Pergamon Press, London.

ICRP72 International Comission on Radiological Protection, 1972, Alkaline Earth Metabolism in Adult Men, ICRP Publication 20, Perganon Press, Dxford.

ICRP74 International Comaission on Radiological Protection, 1974, Reference Man, ICRP Publication 23, Perganon Press, Oxford.

ICRP79 International Commission on Radiological Protection, 1979, Report of Connittee II on Limits for Intakes of Radionuclides by Workers, ICRP Publication 30, Perganon Press, 0xford.

ICRP80 International Commission on Radiological Protection, 1980, The Computational Models and Transfer Coefficients for Dose Assessment, ICRP Draft Report for Conittee IV, ICRP/80/C-4/02 .

Is56 Ishibasi, M., Shigenatsu, T., Ishida, T., Okada, S., Nishi, T., Takahashi, H., Hatsumoto, C., Shimizu, S., Hyodo, T., Hirayana, F., and Okamoto, S., 1956, "Radiochemical Analysis of the Bikini Ashes," in: Research in the Effects and Influences of the Nuclear Bob Test Explosions, Japan Society for the Promotion of Science, Tokyo.

Ja64 James, R.A., 1964, Estinate of Radiation Dose to Thyroids of Fongelap Children Following the BRAVO Event, Lawrence Radiation Laboratory Report, Livermore, CA, UCRL-12273.

JCAE57 Joint Committee On Atomic Energy, 1957, The Nature of Radioactive Fal1-out and Its Effects on Man, Part 1, Washington, DC. 
JCCRRRR56 Japan Comittee for Compilation of Reports on Research in the Effects of Radioactivity, 1956, Research in the Zffects and Influences of the Nuc lear Bomb Test Explosions, Japan Society for Promotion of Science, Tokyo.

Jo81 Johnson, J.R., 1981, "Radioiodine Dosimetry," J. Radioana1. Chen. 65, 223-238.

Jo82 Johnson, J.R., 1982, "Peta1 Thyroid Dose From Intakes of Radioiodine by the Mother," Health Phys. 43, 573-582.

Ra66 Kawahara, F. K., O'Conner, J. D., Lee, H., and Connors, M. A., 1966, Local Fallout From Nuclear Test Detonations, Vo1. III, Defense Atomic Support Agency, San Francisco, CA, DASA 1251.

Ke65 Keisch, B., Koch, R.C., Levine, A.L., 1965, "Determination of Biospheric Levels of I-129 by Neutron-Activation Analysis," in: Modern Trends in Activation Analysis, Texas A\&M University Report, College Station, $T X$.

Ki56 Kimura, K., 1956, "Radiochemical Studies on the Radioactive Dust Due to the Nuclear Detonation at the Bikini Atoll on 1 st March, 1954," in: Research in the Effects and Influences of the Nuclear Bomb Test Explosions, Japan Society for the Promotion of Science, Tokyo.

Ko80 Kocher, D., C., 1980, "Dose Rate Conversion Factors for Externa1 Exposure to Photon and Electron Radiation from Radionuclides Occurring in Routine Releases from Nuclear Fuel Cycle Facilities," Health Phys. $38,543-621$.

Le82 Lee, Yoke-Sun, 1982, "Thyroid Cancers in Singapcre 1968-'77," Trop. Geograph. Med. 34, 303-308.

L865 Lavrenchik, V. N., 1965, Globa1 Fallout Products of Nuclear Explosions, Atomic Energy Commission Report, Washington, D.C., AECtr-6666.

Le78 Lederer, C. M. and Shirley, V. S., Editors, 1978, Table of The Isotopes, Seventh Edition, John Wiley and Sons, Inc., NY.

Le84 Lessard, E. T., Miltenberger, R. P., Cohn, S. H., Musolino, s. V., and Conard, R. A., 1984, "Protracted Exposure to Fallout: The Rongelap and Utirik Experience," Health Phys. 46(3), 511-527.

Ma56 Mather, R.L., 1956, "Brief Summary of Gamma Radiation Spectra from Residual Radiation Sources Following a Nuclear Detonation," in: The Shorter-Term Biological Hazards of a Fallout Field, United States Atomic Bnergy Commission and Department of Defense Report, Washington, DC. 
Ma81 Mattson, Sorën et al., 1981, "Excretion of Radionuclides In Human Breast Milk Following Adninistration of I-125 Fibrinogen, Tc-99-KAM and $\mathrm{Cr}-51$ EDTA," in: Third International Radiopharaceutical Dosimetry Symposium, Conference Proceedings, Oak Ridge, TA, FDA 818166 .

Mi79 Miltenberger, R.P., Greenhouse, N.A., and Lessard, E.T., 1979, "Thole Body Counting Results from 1974 to 1979 for Bikini Island Residents," Hea 1th Phys. 39(3), 395-408.

Mi83 Miltenberger, R. P. and Lessard, E. T., Editors, 1983, Body Burdens and Dose Assessment for Bikini Island Residents, Brookhaven Mationa1 Laboratory Report, Upton, NY, BNL Draft.

Na80 Naidu, J.R., Greenhouse, N.A., Knight, G., and Craighead, E.C., 1980, Marsha11 Islands: A Study of Diet and Living Patterne, Brookhaven Hational Laboratory, Upton, NY, BNL 51313.

No66 Norwent, H. G., Schwenke, T. W., and Kohlberg, I., 1966, Developent of an Improved Land-Surface Fallout Mode1, Technical Operations Research Report, Burlington, MA, TO-B 65-99.

NNDC82 National Nuclear Data Center, 1982, Evaluated Nuclear Data Files, Brookhaven Nationa 1 Laboratory Report, Upton, IT, EIDF BIV.

OC68 O'Conner, J.D. and Crocker, G.R., 1968, Local Fallout Fron Muclear Test Detonations, Defense Atonic Support Agency, Naval Radiological Defense Laboratory, San Fransisco, CA, DASA 1251.

Pe81 Peterson, K., 1981, Castle-Bravo Air Concentration and Deposition Patterns from a 3-D Particle-in-Ce11 Code, Lawrence Livermore National Laboratory Report, Liverwore, CA, UASG 81-20.

Ph82 Phillips, J.C., 1982, A Revised Estinate of the Internal Radiation Doses of American Military Personne1 on Rongerik Atoll, Shot Bravo, Operation Castle, Science Applications, Inc. Draft Topical Report, Schaumburg, IL, DNAOnt-82-C-0012.

RSIC73 Radiation Shielding Information Committee, 1973, Data Library Gn' 'Jction, Radionuc lide Gama-Ray Energy and Intensity Compilation, Oak Ridge Nationa 1 Laboratory Report, Oak Ridge, Ti, ORn-Th-4095.

Sh57 Sharp, R., and Chapman, W., 1957, Exposure of Marshall Islanders and American Military Personne 1 to Fallout, Naval Medical Research Insti- tute, Bethesda, MD, WT-938.

Sk75 Skrable, R., Erench, C., Chabot, G., Kajor, A., and Ward, K., 1974, "Kinetica Equation for Linear Firat-Order Nuclear Phenonena," Iucl. Safety 16, 337-344. 
So55 Sondhaus, C.A. and Bond, V.P., 1955, Physica1 Factors and Dosimetry in the Marshall Islands Radiation Exposures, Naval Medical Research Institute Report, Bethesda, ND, WT-939.

St62 Studier, M., Postmus, H.C., Jr., Mech, J., Walters, R.R., and Sloth, E.N., 1962, "The Use of ${ }^{129} \mathrm{I}$ as an Isotopic Tracer and its Determination Along With Normal 127 I by Neutron Activation - The Isolation of Iodine from a Variety of Materials," J. Inorg. Nuc1. Chem. 24, 755.

Su56 Suito, E., Tokiyama, K., and Uyeda, N., 1956, "Co11oid Morphological and Crystalline Studies of Bikini Dust," in: Research in the Effects and Influences of the Nuclear Bomb Test Explosions, Japan Society for the Promotion of Science, Tokyo.

Ts55 Tsuzuki, M., 1955, "Erfahrungen uber Radioaktive Schadigung der japanische Fisher durch Bikini-2sche," Muench. Med. Wochsch. 31, 988-994.

USPHS59 United States Public Health Service, 1959, Report of the Public Health Service Off-Site Radiological Monitoring Data, Operation Hardtack Phase I 1958, pub1isher unknown, manuscript attached to letter from Lt. Colonel Belmont Evans, (USA) to Robert Conard, M.D., Brookhaven National Laboratory, Upton, NY.

Ya56 Yamatera, 1956, "Radiochemical Analysis of Dust Due To the Thermonuclear Test on March 1, 1954," in: Research in the Effects and Influences of the Nuclear Bomb Test Explosions, Japan Society for the Promotion of Science, Tokyo. 